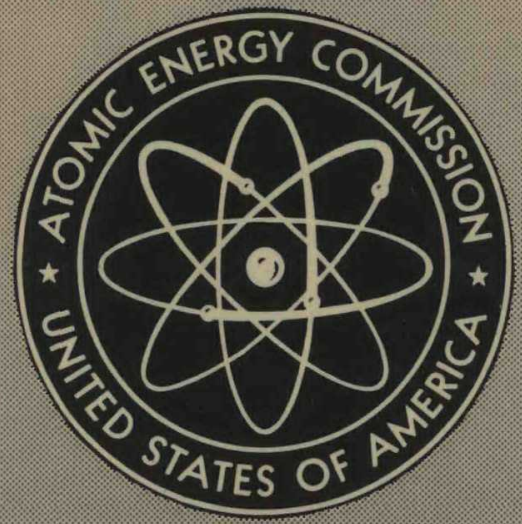

APAE-81

RESEARCH AND DEVELOPMENT REPORTS FOR SODIUM TO SODIUM INTERMEDIATE HEAT EXCHANGER AND SODIUM TO WATER STEAM GENERATOR

October 30,1960

Alco Products, Inc.

Schenectady, New York 


\section{DISCLAIMER}

This report was prepared as an account of work sponsored by an agency of the United States Government. Neither the United States Government nor any agency Thereof, nor any of their employees, makes any warranty, express or implied, or assumes any legal liability or responsibility for the accuracy, completeness, or usefulness of any information, apparatus, product, or process disclosed, or represents that its use would not infringe privately owned rights. Reference herein to any specific commercial product, process, or service by trade name, trademark, manufacturer, or otherwise does not necessarily constitute or imply its endorsement, recommendation, or favoring by the United States Government or any agency thereof. The views and opinions of authors expressed herein do not necessarily state or reflect those of the United States Government or any agency thereof. 


\section{DISCLAIMER}

Portions of this document may be illegible in electronic image products. Images are produced from the best available original document. 


\section{LEGAL NOTICE}

This report was prepared as an account of Government sponsored work. Neither the United States, nor the Commission, nor any person acting on behalf of the Commission:

A. Makes any warranty or representation, expressed or implied, with respect to the accuracy, completeness, or usefulness of the information contained in this report, or that the use of any information, apparatus, method, or process disclosed in this report may not infringe privately owned rights; or

B. Assumes any liabilities with respect to the use of, or for damages resulting from the use of any information, apparatus, method, or process disclosed in this report.

As used in the above, "person acting on behalf of the Commission" includes any employse or contractor of the Commission, or employee of such contractor, to the extent that such employee or contractor of the Commission, or employee of such contractor prepares, disseminates, or provides access to, any information pursuant to his employment or contract with the Commission, or his employment with such contractor.

This report has been reproduced directly from the best available copy.

Printed in USA. Price $\$ 2.50$. Available from the Office of Technical Services, Department of Commerce, Washington 25, D. C. 


\title{
RESEARCH AND DEVELOPMENT REPORTS FOR SODIUM TO SODIUM INTERMEDIATE HEAT EXCHANGER \\ AND \\ SODIUM TO W ATER STEAM GENERATOR
}

\author{
Submitted to \\ UNITED STATES ATOMIC ENERGY COMMISSION \\ CHICAGO OPERATIONS OF FICE \\ 9800 SOUTH CASS AVE. \\ ARGONNE, ILLINOIS
}

Contract No. AT(11-1)-666

October 30,1960

ALCO PRODUCTS, INC. Research \& Development Schenectady, New York 
•

? 
TABLE OF CONTENTS

Page

$\begin{array}{lll}\text { Section } 1 & \text { INTRODUCTION } & 1\end{array}$

Section 2 ELIMINATION OF TUBE END FERRULES 3

Section $3 \quad$ MECHANICAL BEHAVIOR OF SINE WAVE TUBES 15

Section 4 TUBE TO TUBE SHEET WELDED CONNECTIONS 23

Section 5 METALLURGICAL EXAMINATION OF BIMETALLIC TUBES

$\begin{array}{lll}\text { Section } 6 & \text { TRANSITION WELD TEST } & 63\end{array}$

$\begin{array}{lll}\text { Section } 7 & \text { BAYONET TUBE TEST } & 77\end{array}$

$\begin{array}{lll}\text { Section } 8 & \text { BAYONET TUBE WELD CAP TEST } & 105\end{array}$ 


\section{SECTION 1}

INTRODUCTION 


\section{INTRODUCTION}

This report contains the results of research and development work performed in conjunction with the $70 \mathrm{MW}$ design of a sodium to sodium intermediate heat exchanger and a sodium to water steam generator.

This program was carried out as specified in modification number 3 to Contract AT(11-1)-666 Article III, Section 9, items a through h. Because of information that was subsequently developed, a change was recommended in some of the research and development items. These changes are as follows:

Item a:

Kanigen plating was substituted for Inconel overlays and a program to evaluate this plating was undertaken. This program will be completed and reported on during the next phase of work.

Item b:

Because Inconel overlays were not being considered, there was no program for developing welding procedures to weld bimetallic tubes to Inconel overlayed tube-sheets.

\section{Item $\mathrm{f}$ :}

No research and development work was carried out to develop preferred methods for pressure relief in the steam generator. The results of sodium-water reactions, carried out by others, was studied and evaluated. This information was used to aid in establishing the methods proposed for pressure relief in the final design of the $70 \mathrm{MW}$ steam generator.

\section{Item i:}

This item represents an addition to the contract list and was a program undertaken to check the steam generator bayonet tube end cap welds.

This report and other reports previously submitted encompases all items under Section 9 of this contract with the addition and elimination of those items as noted above. 
SECTION 2

ELIMINATION OF TUBE END FERRULES 


\section{TABLE OF CONTENTS}

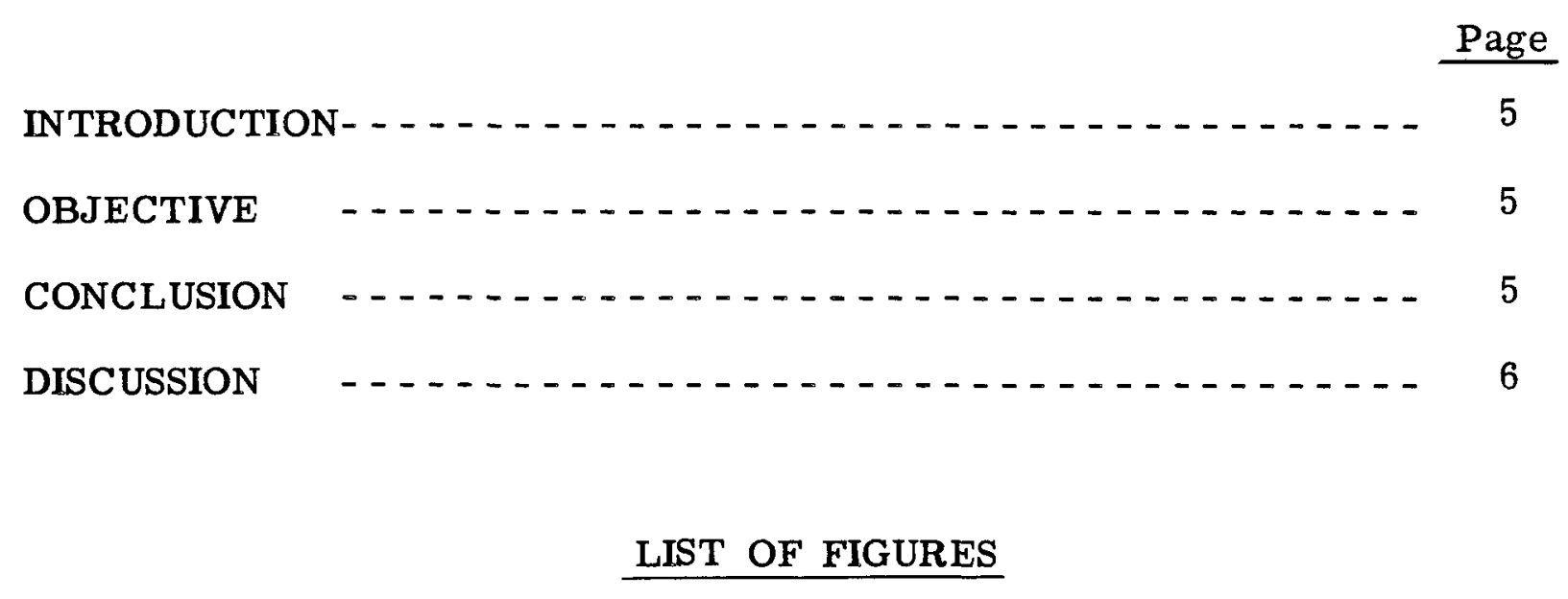

Figure 2-1 Tube Bundle Mock-Up _. $\ldots \ldots \ldots \ldots$

Figure 2-2 Tube Alignment and Puller Rods _. . . . . . . . . . . 13

Figure 2-3 Final Assembly of Tube Bundle Mock-Up _ _ _ _ _ _ 14

\section{LIST OF DRAWINGS}

Dwg. No。

D-160767 Experimental Tube Sheet $\ldots \ldots \ldots$

H-160421 Mock-Up Bundle Assembly _............... 9 


\section{INTRODUCTION}

The designs of the Intermediate Heat Exchanger and the Steam Generator Superheater Section for the Sodium Development Project incorporates fixed tube sheet construction with sine wave tube bundles. Fabrication sequencing dictates that the bundles be built leaving one end of each bundle free until fully assembled and then sliding a closing tube sheet over the entire tube nest.

Initial conceptual design accomplished this final assembly phase by using over size tube holes in the closing tube sheet. Ferrules were to be inserted between this hole I. D. and the tube O.D. after assembly and seal welding was then to be performed between tubes, ferrules and tube sheet.

A suitable alternate assembly procedure was investigated whereby the ferrule concept could be eliminated. The following is a report of this investigation.

\section{OBJECTIVE}

To develop a suitable tube sheet to tube bundle assembly procedure, by means other than ferrules, for the Superheater and Intermediate Heat Exchanger components in order to reduce the number of crevices and possible sources of leaks.

\section{CONCLUSION}

The tube sheet to bundle assembly for all stainless units can be achieved without the use of ferrules and without risk of galling the tubes or tube holes.

The procedure developed is as follows:

1. Hole size for tube sheets are to be a nominal .020" larger than nominal tube O.D.

2. Individual positioning rings for each tube row are to be furnished. Tube holes in the rings are to be a nominal .016" larger than nominal tube $\mathrm{O}$. D.

3. Tube guide rods, 3/8" diameter and orientation sleeves $1 / 2$ in. $O . D$. approximately 16 " long will be required. Guide rods will be 
threaded for engagement with the sine tube only; full length threading is not required.

4. Tube support will be assembled horizontally with the lower tubesheet. Tube rows will be inserted into the supports and lower tube sheet one row or ring at a time. This is to be accomplished by inserting tubes into the supports, snapping over the tube row positioning ring and redrawing back through the ring to proper orientation. Tubes are then to be rolled in the lower tube sheet and positioning ring. This procedure is to be repeated for each row until the entire tube nest is assembled and oriented.

5. The closing or upper tube sheet is to be moved into position by an overhead crane. Guide rods previously installed in tube ends are to be engaged by feeding the orientation sleeves through tube sheet holes to engage the rods. The tube sheet is to be slowly moved forward by continuing this process until all tube rows have entered the back face of the tube sheet. The tube sheet is then placed on a movable table or support and a jack forces the tube sheet into proper position.

6. Tubes are trimmed and final joints welded.

\section{DISCUSSION}

This investigation consisted of two phases: (1) the determination of the optimum tube hole size in the tube sheet and (2) the development of a practical bundle assembly procedure.

\section{Phase 1}

As the tube hole size affects the subsequent assembly concept, the first phase consisted of determining the maximum tube hole diameter which could be accommodated from a mechanical analysis standpoint as well as ease of assembly. Within reasonable limits, the larger the permissible tube hole diameter, the easier the bundle can be assembled with the tube sheet. In order to determine the optimum hole diameter, a 3 " thick, $13^{\prime \prime}$ long by 5 " wide, stainless steel plate was machined as indicated on Drawing D-160767. Seventy-two tube holes were drilled and reamed in six rows with varying diameters. The hole diameters ranged from .510" to .540" with twelve holes for each increment. After the drilling was completed, all tube holes in the test plate were individually identified and their corresponding tubes similarly marked. Tube hole inside diameters were measured and recurded.

A total of 36 IHX, plus 36 superheater tubes were cut to 9 " length. The tubes outer and inner diameters were also gauged and recorded. 
The tubes and tube sheet holes were then cleaned to insure removal of all contaminations; oil, grease,grit, etc.

The tubes were placed in the tube holes and expanded to metal contact with the test plate in two stages. Stage one consisted of rolling from the outer face of the test plate to approximately the middle of the test plate. Stage two rolled from the middle of the test plate to approximately $1 / 8$ " from the back face. An air tool expander with an electric precision control was used for the rolling operation, calibrating 3.9 LO reading for the bimetallic tubes and 3.5 LO for the solid stainless tubes. Air Tool No. 20, 21 and 22 expander rollers were utilized for the expanding. Visual observations during the rolling operation indicated that the tubes were not turning in the tube holes. After completion of the rolling, the inside diameters of the as-rolled tubes were measured and recorded and the test plate was subjected to a mechanical and metallurgical review in conjunction with a review of stress analysis calculations to determine the optimum hole size. It was determined the optimum nominal hole size was . 520".

During fabrication of the tube bundle section, it became apparent that some positive means would have to be devised to assure accurate positioning and holding of the sine section of the tubes during their expansion into the closing tube sheet. Preliminary assembly methods did not indicate that tubes should be expanded into the positioning rings until after the tube sheet had been installed, so it became necessary to devise a method for insuring sine wave tube alignment when rolling blind. Permanent banding or spacing equipment could not be accommodated and possible use of Cerrobend for positioning was investigated. This material is a low melting bismuth alloy and it was thought that orientation bands could be made and later removed by hot flushing after expanding. Several methods and media were examined for the band removal without satisfactory results because of residual oxides from the Cerro-bend.

In view of this, it was decided to modify the assembly procedures slightly by expanding the tubes into the positioning rings prior to installation of the tube sheet. These changes were incorporated in the second phase of the assembly procedure.

\section{Phase II}

The prototype bundle components were partially fabricated during Phase I. Upon determination of tube hole size, the simulated spherical tube sheet was machined and drilled. Refer to Design Sketch H-160421 for bundle details.

The actual assembly consisted of two methods as follows: 


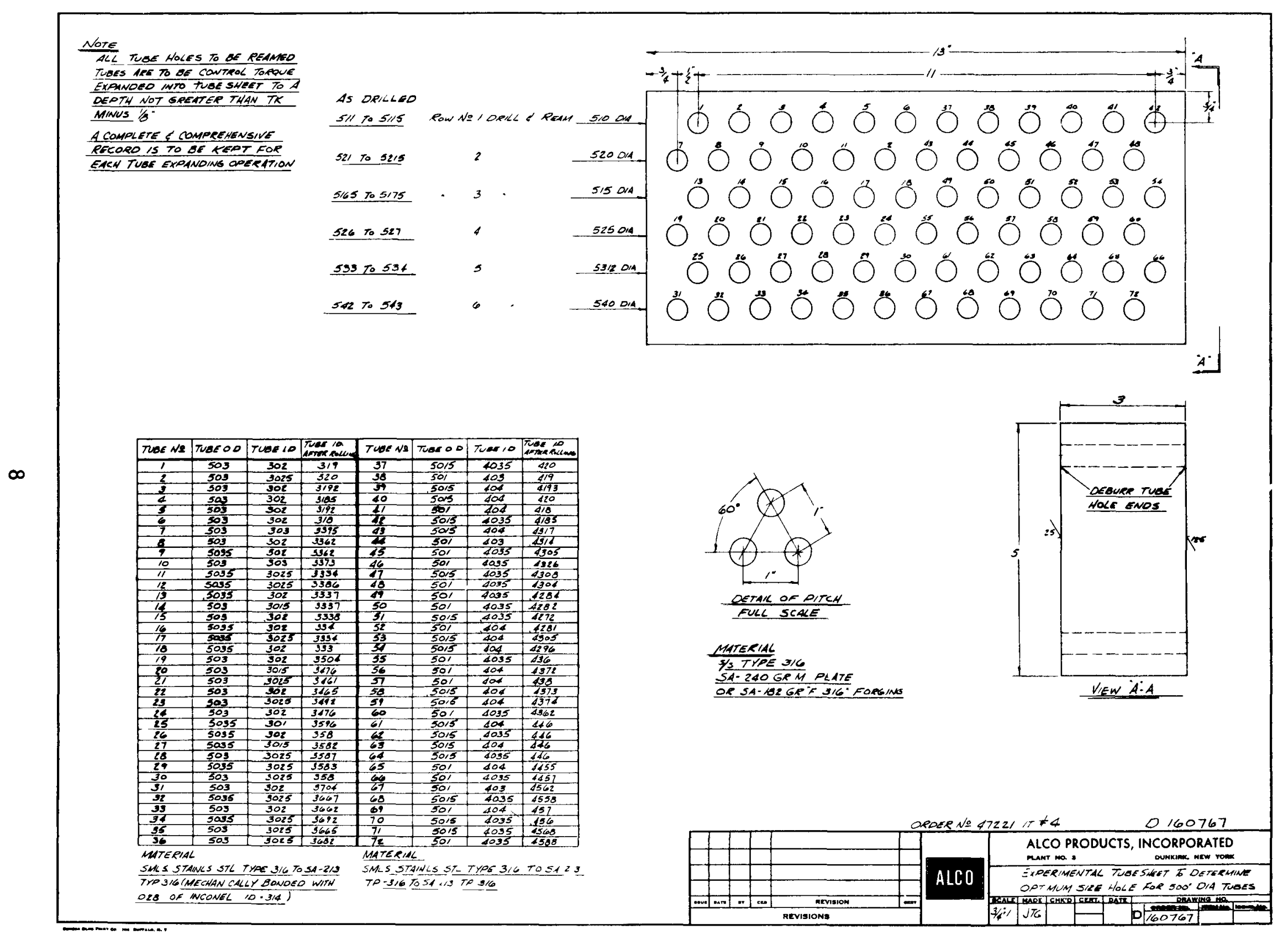




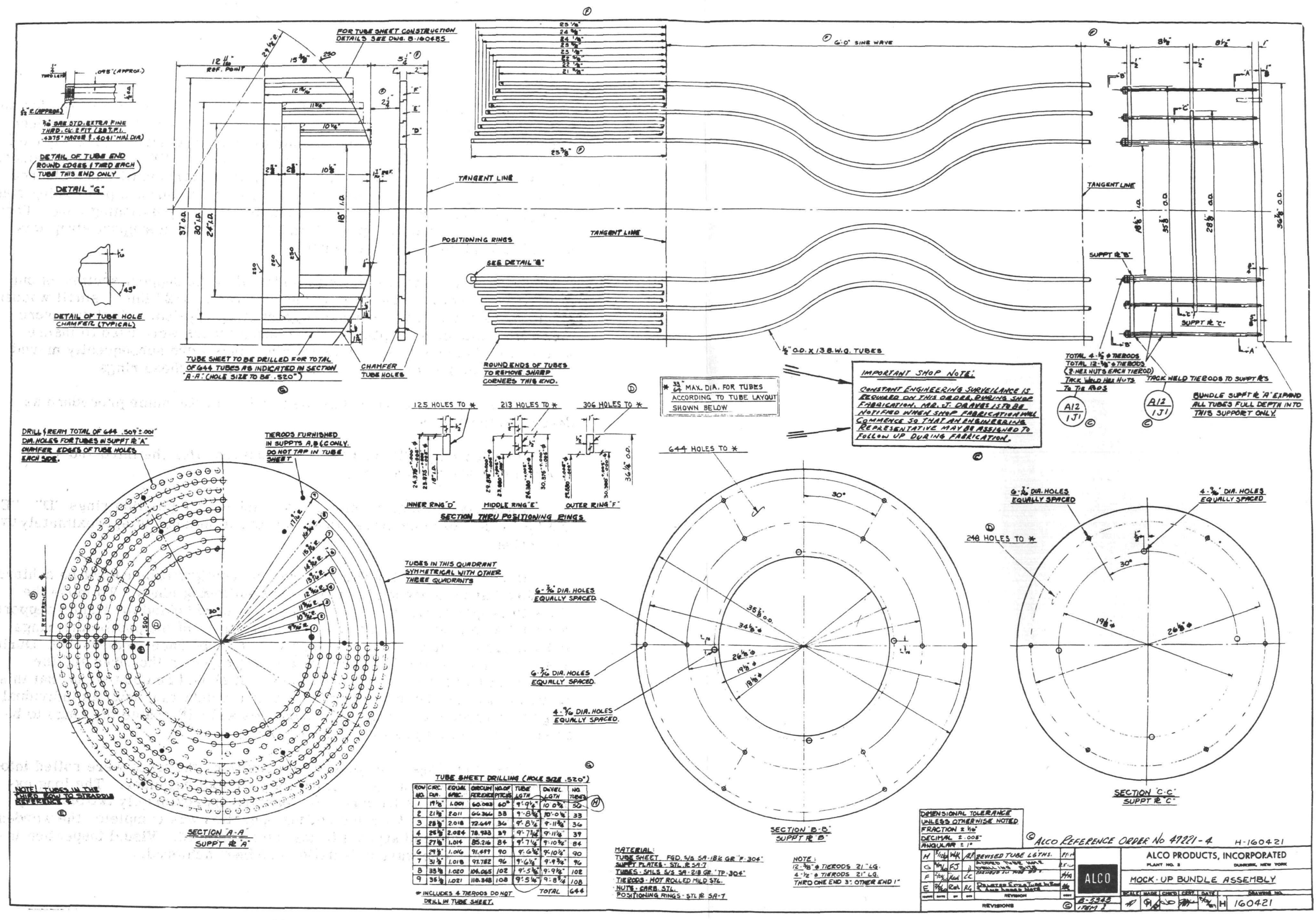


Method A

The inner row of tubes was installed in the bundle support section and support plates B, C and A. At the center of the sine section, a two piece wooden circle was placed with cut-outs for tube alignment. (See Figure 2-1.) The tubes were snapped into the inner position ring " $D$ ". Snapping procedure consisted of guiding the tubes into the bundle supports until tubes cleared the positioning ring. Then the tubes were redrawn through positioning ring until proper tube extension was obtained beyond the positioning ring. Then the tubes were rolled into support plate " $A$ ". Next, a support strap was banded around the tubes and tightened.

The second row of tubes was installed in the support section as outlined above. Between the first and second rows, 1/2" thick, small wooden blocks were placed and a second support strap applied. The tubes were chen rolled into support plate " $A$ ". Wooden blocks were used to insure sine wave alignment when the positioning rings were subsequently moved to their proper location prior to tube expansion in these rings.

- The third row of tubes was installed using the same procedure as described for row two.

Position rings "E" and "F" were applied after the third and sixth row of tubes were installed.

Upon assembling, all nine rows of tubes, the position rings " $D$ ", " $E$ " and "F" then had to be moved into position, a distance of approximately twentytwo inches.

Because identical bending of the sine configuration cannot be achieved, the tubes have a tendency to bind in the positioning rings. To move the rings to proper location, brackets were fastened behind the bundle support section " $A$ " and approximately 20" from the face of the positioning rings and a hydraulic jack was applied between the tube sheet and bracket. During this operation, mineral oil lubricant was sprayed on the tubes and the positioning rings were forced into place. It should be pointed out that this operation will not be necessary for the final production unit, as individual rings will reduce tube snapping clearances and will enable the rings to be oriented in correct position without forcing.

After the rings were placed into position, the tubes were rolled into the positioning rings using an extra long air tool expander. The long expander is required as the position rings are approximately two feet away from the tube ends. When the rolling operation was complete, the wooden block, half circle and support bands were removed. Visual inspection indicated proper sine wave orientation had been achieved. 


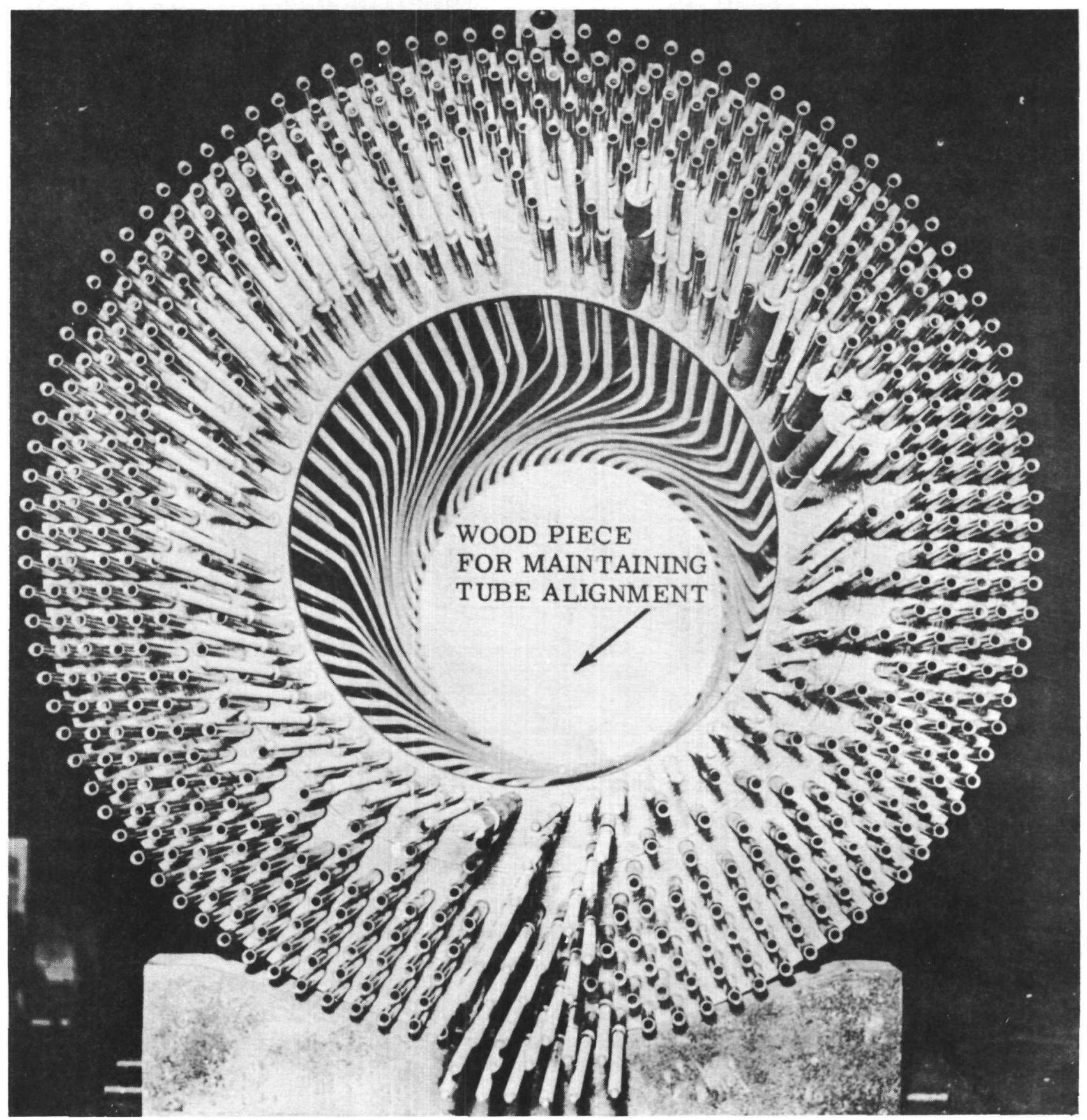

FIGURE 2-1 TUBE BUNDLE MOCK-UP 
In every tube a bullet shaped rod was threaded into the tube end. (See Figure 2-2.)

The tubes and spherical tube sheet were then cleaned and the tube sheet placed on a movable table and lined up horizontally and vertically with the bundle. The tube sheet was moved forward, until the first row of tubes hit the back face of the tube sheet and every tube was put into the proper tube hole by hand, and the tube sheet moved forward. All tubes had to be placed in their individual holes by hand in all subsequent rows. The tube sheet was moved gradually forward as tube rows were engaged. When the lead rods of the first row of tubes passed the front face of the tube sheet, nuts were put on these rods, hand tightened, and the tube sheet moved forward. On the second, third and fourth rows of lead rods, nuts were also applied and tightened. The table was moved very slowly during this operation. When the tubes started to bind, the guide nuts were again tightened,which resulted in freeing the interfering tubes, and the tube sheet then moved forward until binding again occurred. It was necessary to use the guide rod spacers on the inner rows during the later stages of the operation as the threaded portions of the rods projected beyond the tube sheet face.

Upon engaging all tubes in the tube sheet, a steel cross bar was fabricated and put on the vertical and horizontal center lines of the tube sheet. A hydraulic jack was then applied and the tube sheet was jacked in to position.

The tube sheet was removed and the tube holes of the tube sheet were checked and gauged. No damage or any defects were observed. The tubes were also checked for galling and scratches, with no evidence of either; however, some spots on the tubes were burnished.

\section{Method B}

To reduce the time required to engage the tubes with the tube sheet by hand, 16" long, $1 / 2 \mathrm{O} . \mathrm{D}$. guide sleeves were put into the tube holes of the tube sheet. The tube sheet was picked up with a crane, lined up with the bundle and moved forward. All the first four rows of tubes were entered through these guide sleeves into their proper tube holes without difficulty. The tube sheet was then unhooked from the crane and put on the movable table. Using the sleeves,all tubes entered very easily in their proper holes, and by applying a jack, the tube sheet was readily placed into position. Figure 2-3 shows the tube bundle mock-up with alignment rods installed in each tube and the tube sheet in position for assembly. 


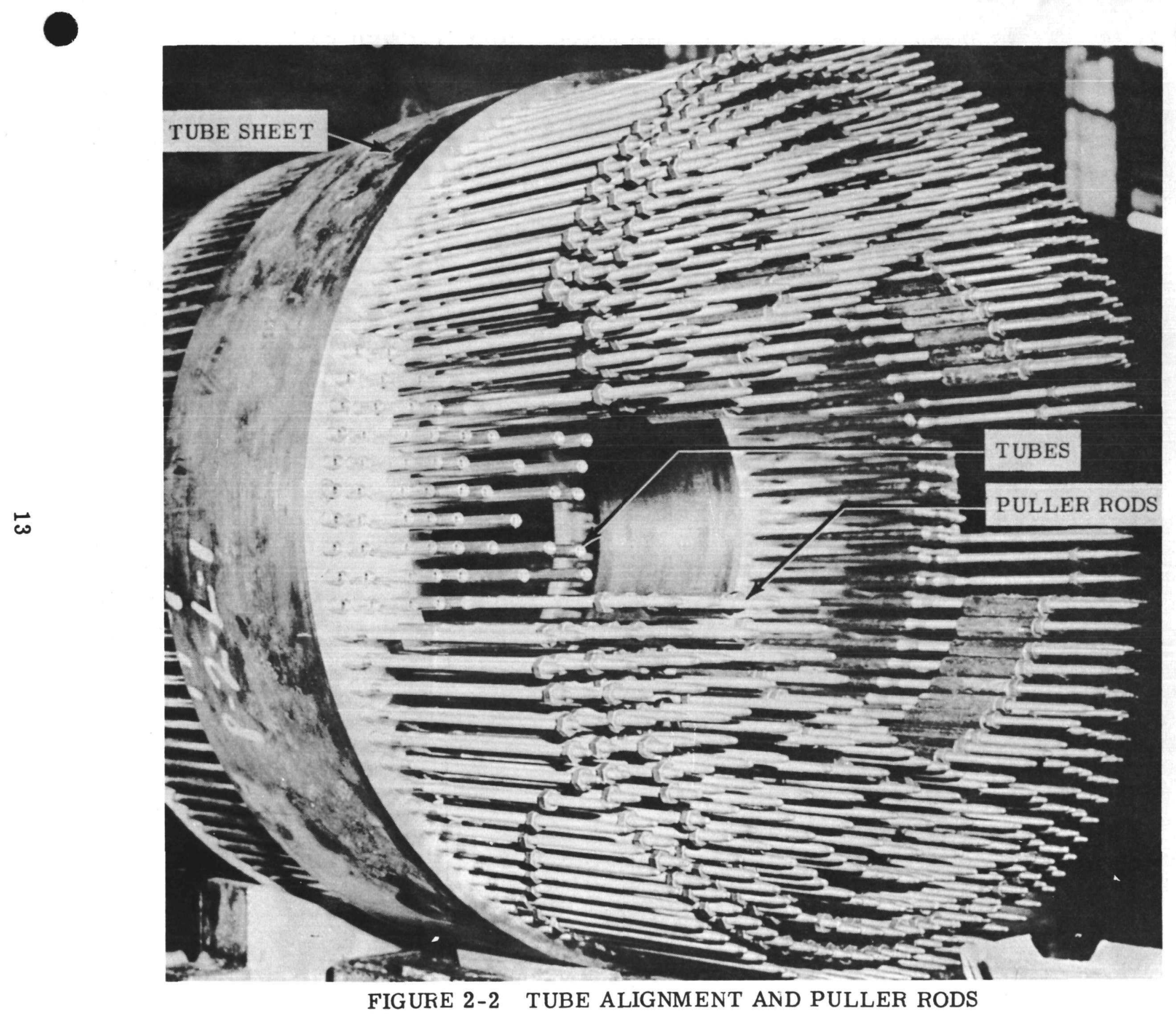




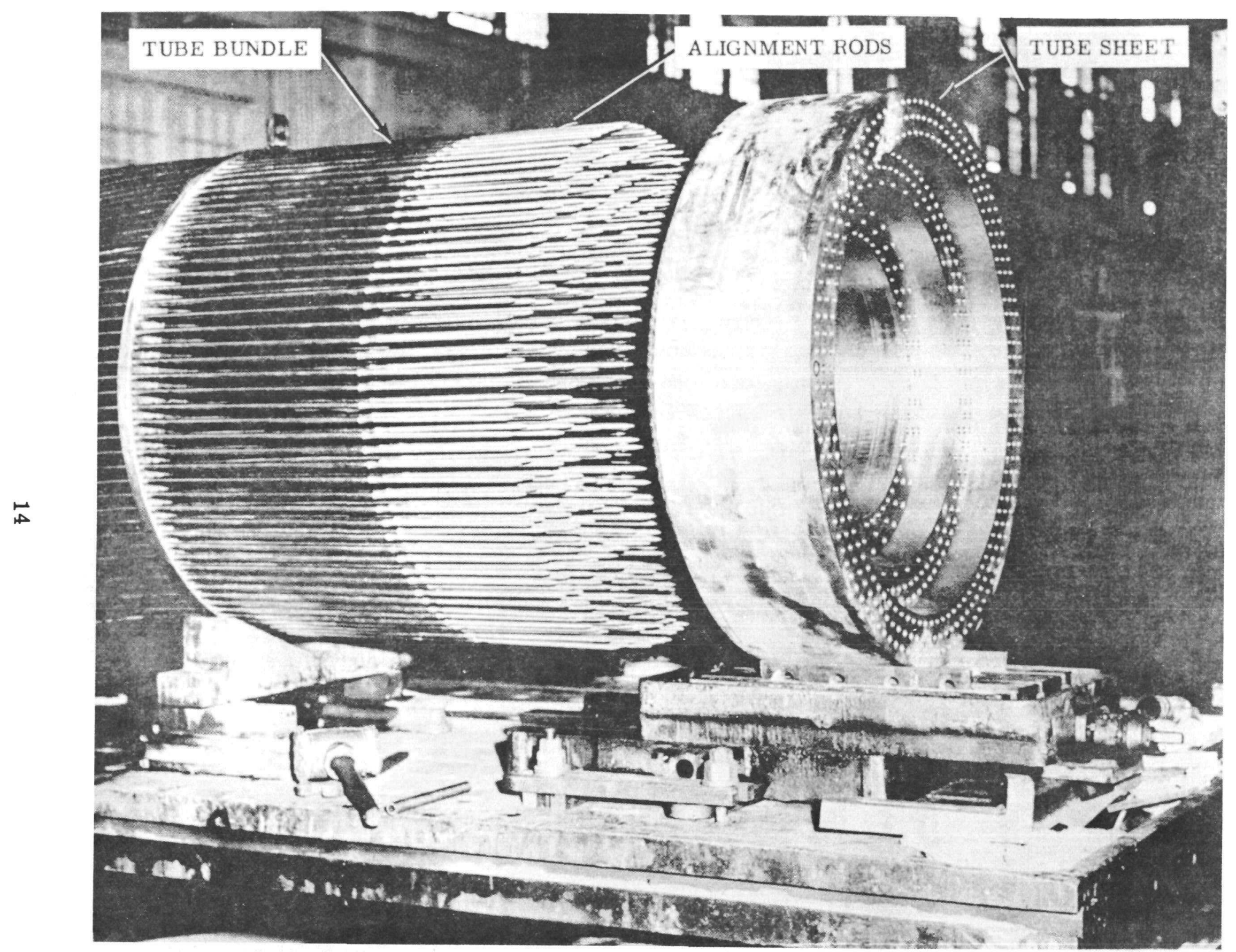

FIGURE 2-3 FINAL ASSEMBLY OF TUBE BUNDLE MOCK-UP 
SECTION 3

MECHANICAL BEHAVIOR OF SINE WAVE TUBES 
MECHANICAL BEHAVIOR OF SINE WAVE TUBES

TABLE OF CONTENTS

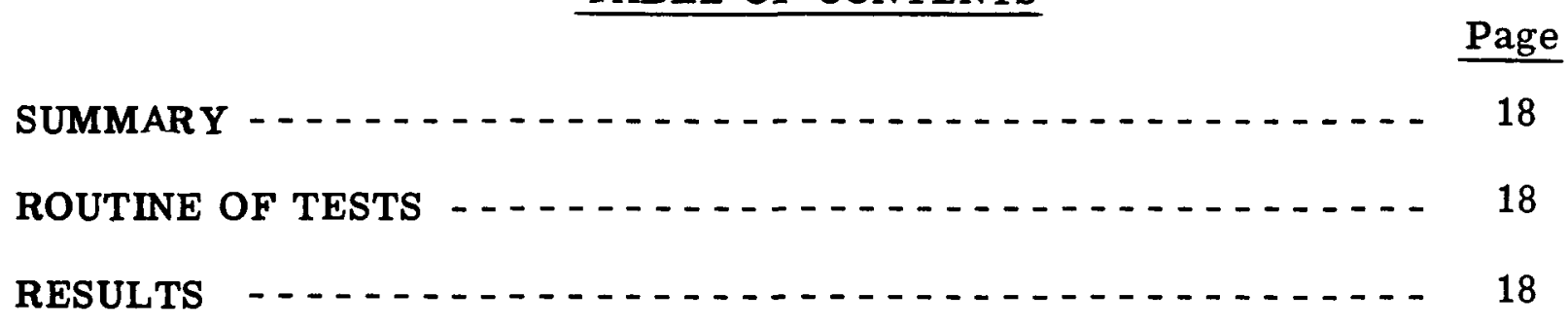

\section{LIST OF FIGURES}

Figure 3-1 Sine Wave Tube Test Stand _. $\ldots \ldots \ldots 17$

Figure 3-2 Fatigue Stress at Failure _...

LIST OF TABLES

Table 3-1 Fatigue Tests $\ldots \ldots \ldots \ldots$ 


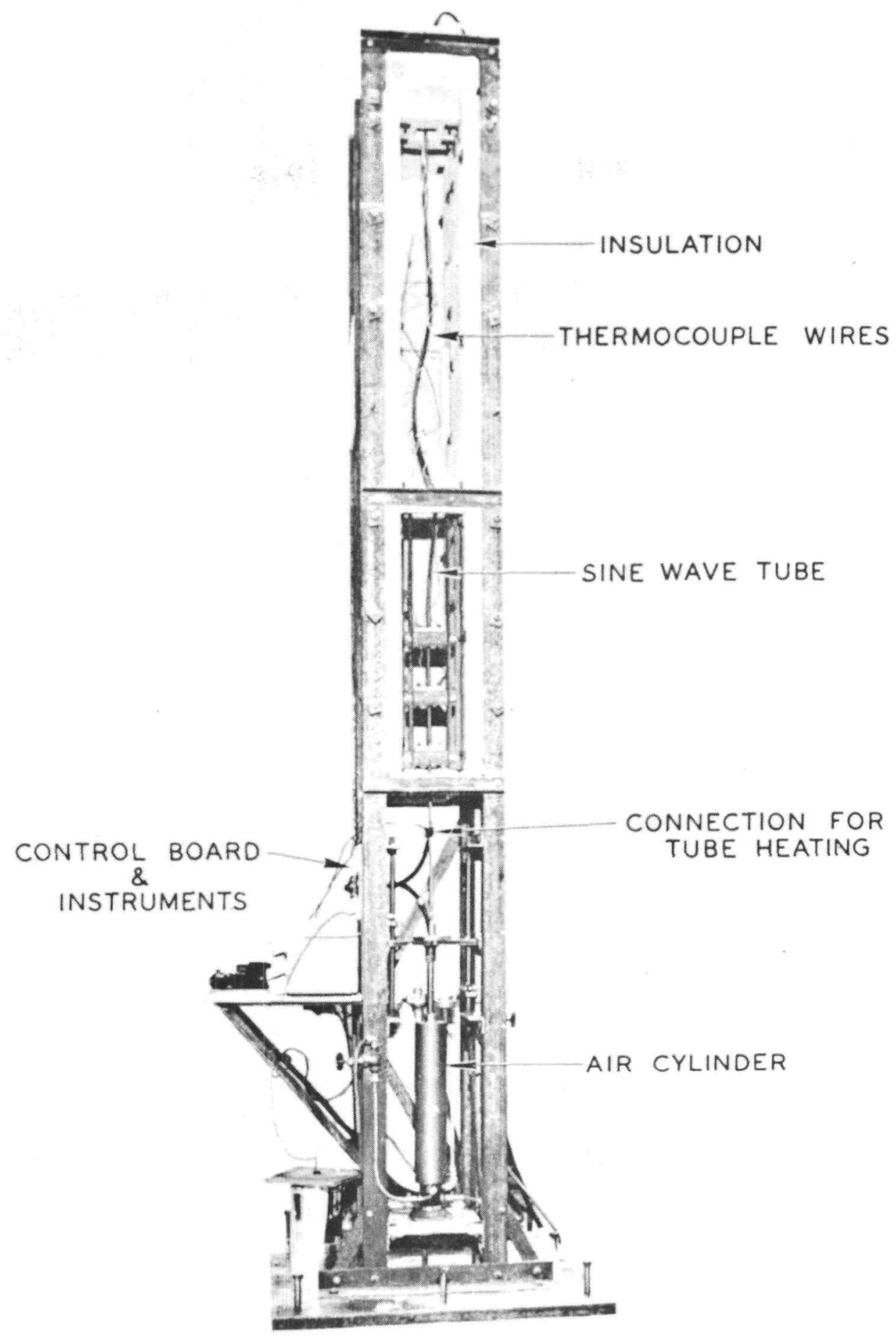

\section{SINE WAVE TUBE TEST STAND}

FIGURE 3-1 


\section{SUMMARY}

When rapid changes in temperature occur in fluids flowing through heat exchangers, the thin-walled tubes respond to the temperature changes much more rapidly than do the thicker heat exchanger shells. This results in differential longitudinal expansion between tubes and shell. To provide enough yield in the tubes to care for these different expansions, curved sections of tubing,spoken of as sine waves, have been provided at the upper ends of both the intermediate heat exchanger and the superheater.

The purpose of this test has been primarily to furnish experimental proof that the sine wave tubes as designed will satisfy this requirement physically at the expected operating temperatures, and that they would not be caused to fail by any expected number of repetitions of these sudden temperature changes during the life of the equipment.

A secondary, but equally important, purpose of this test is to furnish information as to permissible values of fatigue stress in Type 316 stainless steel material, for various numbers of stress repetitions at the peak temperature of $1150-1200^{\circ} \mathrm{F}$.

\section{ROUTINE OF TESTS}

The desired differential expansion was simulated by supporting vertically ten foot lengths of tubing which contained sine wave sections four or five feet long and forcing the lower end up or down by the desired amounts, using an air piston. The tube was pressured with argon gas. Any cracks developed in the tube caused the pressure to drop, stopping the test. The number of complete cycles required to cause failure was recorded. Electricity flowing through the tube maintained the sine wave portion at $1150-1200^{\circ} \mathrm{F}$, as measured by a thermocouple at the midpoint of the wave. All failures were of the fatigue type, at right angles to the length of the tube, at or near the midpoint of the wave, starting on the inside of the curve.

\section{RESULTS}

The tubes tested in this way withstood the number of cycles of stress indicated below before failing: 
Tubes for Heat Exchanger

Waves - 50" long, 10" offset

Stroke

$+1.5^{\prime \prime}$ to $-1.5^{\prime \prime}$

$+2.0^{\prime \prime}$ to $-2.0^{\prime \prime}$

$+2.0^{\prime \prime}$ to $-2.0^{\prime \prime}$

$+2.0^{\prime \prime}$ to $-2.0^{\prime \prime}$

$+2.5^{\prime \prime}$ to $-2.5^{\prime \prime}$
No, of Cycles

18,422

3,667

2,194

4,997

1,037
Tubes for Superheater

Waves 60" long, 12.5" offset

Stroke No. of Cycles

$\pm 1.98 " \quad 10,670$

$+2.0^{\prime \prime} \quad 17,301$

$\pm 2.1 " \quad 5,010$

$\pm 2.5^{\prime \prime} \quad 8,859$

$\pm 3.05^{\prime \prime} \quad 4,446$

$\pm 4.0^{\prime \prime} \quad 2,510$

$\pm 4.0^{\prime \prime} \quad 2,259$

In the intermediate heat exchanger, the sine waves will, by specification, be required to withstand for 25 cycles a differential movement of +0.55 inch and of -0.49 inch. The corresponding figures for the superheater are 25 cycles from +0.59 inch to -0.89 inch.

These values indicate a very large margin of flexibility in the sine waves; so large that it is recommended that the sine waves for the superheater be reduced in dimensions to correspond to those for the intermediate heat exchanger.

Data as to the fatigue strength of Type 316 stainless steel at temperatures above $700^{\circ} \mathrm{F}$ have been very scanty. The values selected for use in the design have been based on the best available information, and these sine wave tests constitute a valuable opportunity to verify the values which have been used.

Computed values of stress for the different specimens tested are given in the accompanying table, and are also shown plotted on a log chart against number of repetitions to failure. The experimental values run approximately twice the previously chosen design values for alternating stress.

\section{Additional tests are planned to check:}

1. Fatigue values at room temperature, $600^{\circ} \mathrm{F}, 900^{\circ} \mathrm{F}$ and $1400^{\circ} \mathrm{F}$, for comparison with those at $1200^{\circ} \mathrm{F}$.

2. The effect of internal pressure in the tube upon cycles to failure in bending.

3. The effect of slow speed cycling; one cycle per hour rather than 10 to 20 per minute. As a practical method of saving time, 60 cycles of large amplitude at low speed will be followed by cycling at normal speed until failure occurs. 
TABLE 3-1

FATIGUE TESTS - SINE WAVE TUBES

Temperature at Midpoint $=1175-1200^{\circ} \mathrm{F}$.

$$
E=21,000,000 \text { psi }
$$

Intermediate Heat Exchanger Tubes Type 316 S tainless Steel-.049" Wall

Offset at $\mathbf{E}$

s Straight-Top Bottom

Stroke

Bending Stress Upstroke

Downstroke

Average

Direct Stress

Alternating Stress

Cycles to Failure

$$
\text { Tube No. }
$$

1

50.75

6

9.06

9.0

8.90

49. 64

8. 75

$\begin{array}{rrrr}4 " & 4 " & 4 " & 6 " \\ 11.75 & 12.13 & 11.66 & 10.56\end{array}$

$+2.5^{\prime \prime}$

$\pm 1.5$

$\pm 2.0^{\prime \prime}+2.0^{\prime \prime}$

72,500

113,000

46,500

60,700

$60,70062,500$

$86,40089,000$

92,750

53,600

$73,550 \quad 75,750$

$$
1,600
$$

970

$1,300 \quad 1,340$

94,350

54,600

1,037

18,422

3,667

2,194

\section{Superheater Tubes}

Type 316 Stainless Steel Lined with Inconel

\begin{tabular}{llllllll}
\multicolumn{7}{c}{ Tube No. } \\
$1 I$ & $2 I$ & $3 I$ & $4 I$ & $5 I$ & $6 I$ & $7 I$ & $8 I$
\end{tabular}

$\begin{array}{llllllll}60.0 & 60.0 & 62.37 & 61.5 & 61.0 & 60.94 & 61.0 & 50.25\end{array}$

$\begin{array}{llllllll}11.19 & 10.87 & 10.50 & 10.75 & 10.81 & 11.81 & 11.50 & 10.19\end{array}$

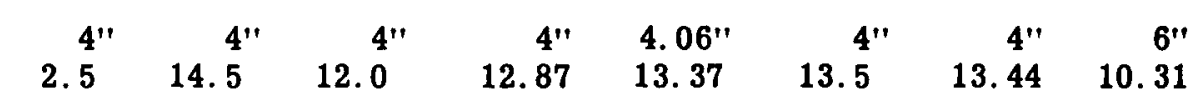

$\pm 2.1^{\prime \prime} \pm 2.5^{\prime \prime} \pm 3.05^{\prime \prime} \quad \pm 4.0^{\prime \prime} \pm 1.98^{\prime \prime} \quad \pm 4.0^{\prime \prime} \quad \pm 2.0^{\prime \prime} \quad \pm 2.0^{\prime \prime}$

$\begin{array}{rrrrrrrr}46,800 & 52,400 & 63,300 & 77,600 & 42,400 & 70,800 & 36,900 & 52,500\end{array}$

$\begin{array}{llllllll}63,500 & 75,300 & 98,800 & 143,800 & 56,500 & 131,200 & 49,200 & 74,800\end{array}$

$\begin{array}{llllllll}55,150 & 63,850 & 81,050 & 110,700 & 49,450 & 101,000 & 43,050 & 63,650\end{array}$

$\begin{array}{llllllll}690 & 790 & 980 & 1,440 & 630 & 1,300 & 540 & 830\end{array}$

$55,850 \quad 64,650 \quad 82,050 \quad 112,100 \quad 50,100 \quad 102,300 \quad 43,600 \quad 64,500$

$\begin{array}{llllllll}5,010 & 8,859 & 4,446 & 2,510 & 10,670 & 2,259 & 17,301 & 4,997\end{array}$ 


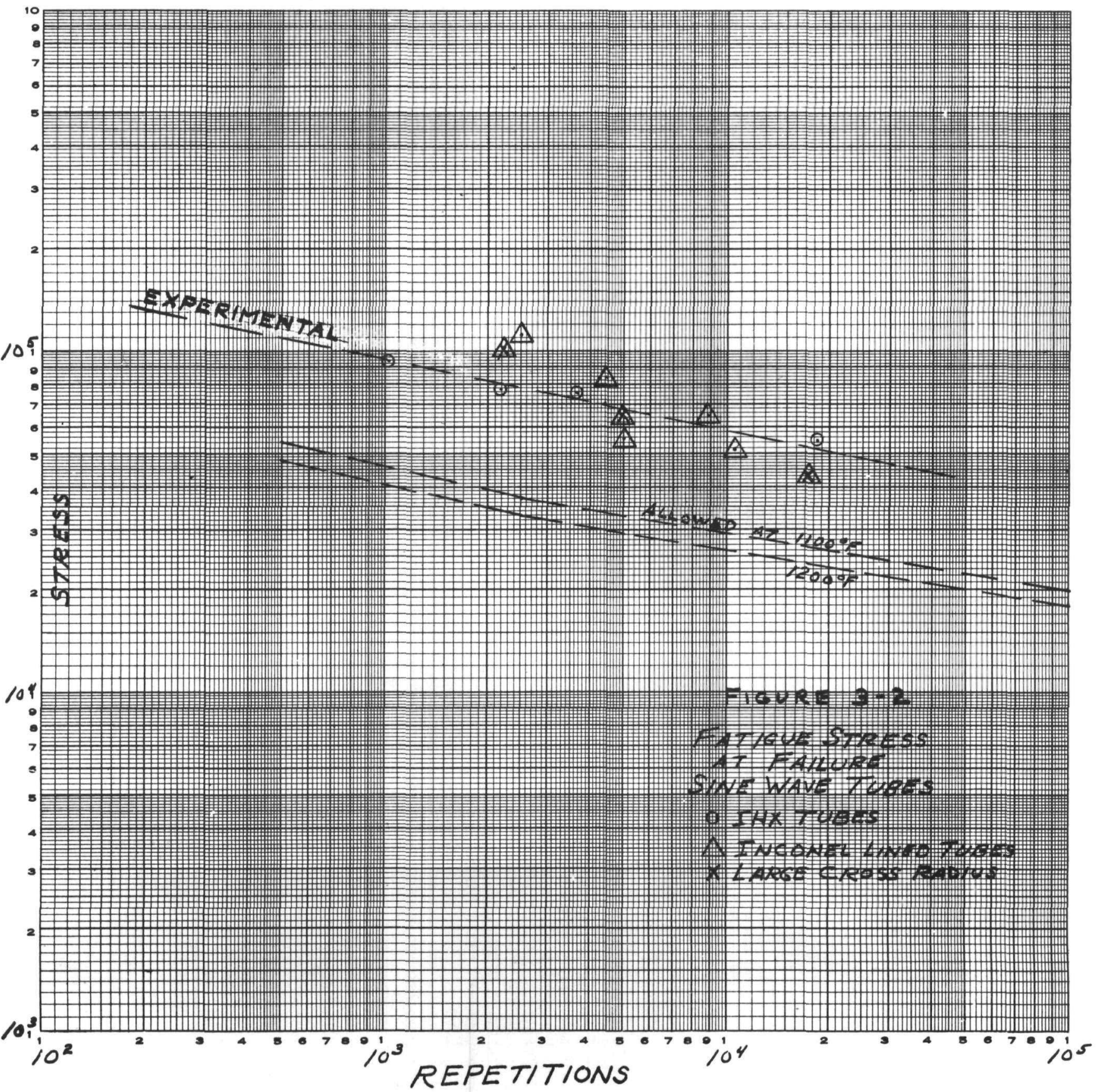

FIGURE 3-2 
- 
SECTION 4

TUBE TO TUBESHEET WELDED CONNECTIONS 
TUBE TO TUBESHEET WELDED CONNECTIONS

TABLE OF CONTENTS

Page

Introduction - $\ldots \ldots \ldots \ldots$

Conclusions and Recommendations _.

General Procedure _. $\ldots \ldots \ldots \ldots$

Description of Test Units _.

Test Equipment $\ldots \ldots \ldots \ldots$

Procedure for Test Unit - Number One Carbon Steel Tubesheet _. - . 32

Results of Carbon Steel Tubesheet Tests _. $\ldots \ldots \ldots \ldots$

Test Units - Number Two and Three

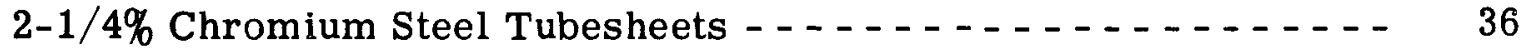

Results of 2-1/4\% Chromium Steel Tubesheet Tests _ _. _ _ _ _ - 41

Test Units - Number Four and Five

Type 316 Stainless Steel Tubesheets _. . . . . . . . . . . . . 43

Results of Type 316 Stainless Steel Tubesheet Tests _. _ _ _. _ _. 49

Metallurgical Inspection _. $\ldots \ldots \ldots$ 


\section{LIST OF FIGURES}

Page

Figure 4-1 Tube to Tubesheet Welded Connections Test Stand

Figure 4-2 Furnace Arrangement

30

Figure 4-3 Pressure Test Arrangement

Figure 4-4 Thermocouple Locations - Carbon Steel Tubesheet

Figure 4-5 Cracks in Flush Weld - Carbon Steel Tubesheet

Figure 4-6 Close-Up View of Cracks in Flush Weld Carbon

Figure 4-7 Air Bubble Accounting for Failure of Only Weld Which Cracked Due to Thermal Stresses

Carbon Steel Tubesheet

Figure 4-8 Thermocouple Locations - 2-1/4\% Chromium

Steel Tubesheet

Figure 4-9 Typical Thermal Cycle Curves - 2-1/4\% Chromium Steel Tubesheet (Flush Joints)

Figure 4-10 Thermocouple Locations - Type 316 Stainless

Steel Tubesheet

Figure 4-11 Typical Thermal Cycle Curves - Stïinless sieel

Tubesheet (Flush Joints) - Spray Cooled

Figure 4-12 Typical Thermal Cycle Curves - Stainless Steel Tubesheet (Flush Joints) Cooled by Water Flow Through Tubes

Figure 4-13 Typical Thermal Cycle Curves - Stainless Steel Tubesheet (Trepanned Joints) Spray Cooled

Figure 4-14 Typical Thermal Cycle Curve - Stainless Steel Tubesheet (Trepanned Joints) Cooled by Water Flow Through Tubes

Figure 4-15 Trepanned Tube to Tubesheet Welded Joint

Figure 4-16 Fissure Extending from Corroded Crevice into Weld Zone 


\section{LIST OF FIGURES (CONT'D)}

Page

Figure 4-17 Flush Tube to Tubesheet Welded Joint

Figure 4-18 Intergranular Corrosion Crack Extending into Tubesheet

Figure 4-19 Intergranular Corrosion Crack Extending into Tube

LIST OF TABLES

Page

Table 4-1 Carbon Steel Tubesheet Cycle Test

Table 4-2 Thermocouple Data - Carbon Steel Tubesheet

Table 4-3 2-1/4\% Chromium Steel Tubesheet Cycle Test (Flush Joints)

Table 4-4 2-1/4\% Chromium Steel Tubesheet Cycle Test (Trepanned Joints)

Table 4-5 Stainless Steel Tubesheet Cycle Test (Flush Joints)

Table 4-6 Stainless Steel Tubesheet Cycle Test (Trepanned Joints) 


\section{TUBE TO TUBESHEET WELDED CONNECTIONS}

\section{INTRODUCTION}

In designing the intermediate heat exchanger, boiler and superheater, the question arose concerning the ability of flush welds between the tubes and tubesheet to withstand the rapid thermal transients that would occur in the unit. An alternate to these flush welds was then considered, which included the use of tube-to-tubesheet welded connections with trepanned risers.

These would reduce the maximum stresses in amount, and would shift them away from the notch concentration points at the root of the weld.

It was with the above in mind, that a test was undertaken to study the behavior of tube-to-tubesheet welded connections, both with and without trepanned risers, under rapid thermal transients. The test stand used for this test is shown in Figure 4-1.

\section{CONCLUSIONS AND RECOMMENDATIONS}

The most serious danger connected with a tube-to-tubesheet weld appears to be corrosion or stress corrosion in the crevice between the tube and the tubesheet. To minimize this, the tube and tubesheet hole should be thoroughly cleaned before assembly, and should be kept clean and dry. The unit should not be tested under water pressure, as the water will be driven into the crevice, and water or corrosion products may remain to cause trouble.

The ductile metals used for these tests show a surprisingly high resistance to damage from even very large thermal strains, unless many times repeated. This was particularly evident in the defective carbon steel welds, which contained initial porosity, but which did not crack in spite of very high stress concentrations. A third carbon steel weld, with an air bubble halfway across its width, resisted two hundred cycles before leaking.

This resistance was also evidenced by the absence of any failures in properly welded joints, either flush or trepanned type. This indicates that trepanning can be omitted for the boiler tubesheet and for the lower tubesheets in the intermediate heat exchanger and the superheater. For upper tubesheets in the intermediate heat exchanger and the superheater, the riser produced by trepanning can be reduced in height to 0.25 inch, or simply a semi-circular groove surrounding the tube hole. 


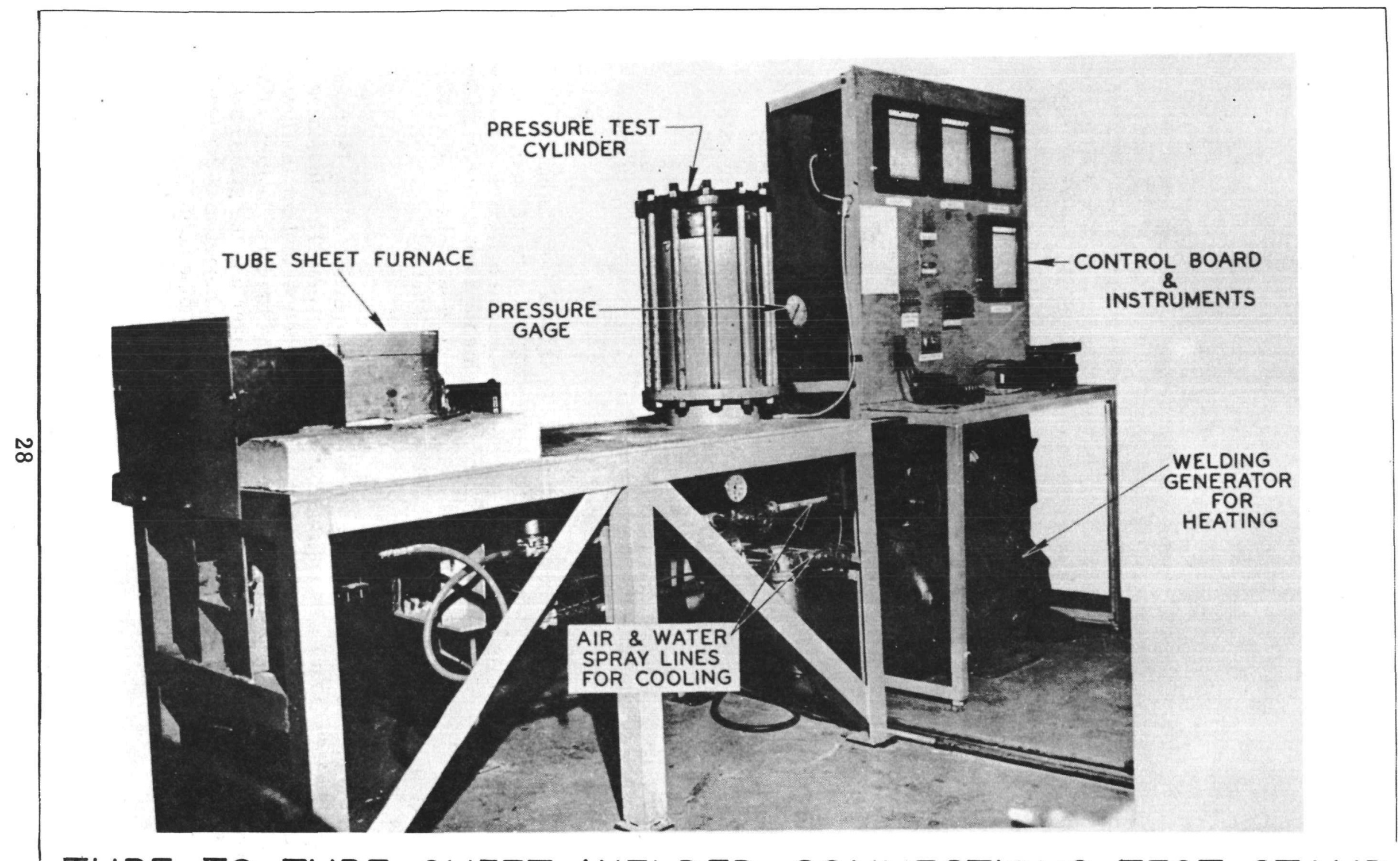

TUBE TO TUBE SHEET WELDED CONNECTIONS TEST STAND 


\section{GENERAL PROCEDURE}

The test units used consisted of dummy tubesheets, twelve inches in diameter by three inches thick, to which were welded either twelve one-half inch diameter tubes, or six two inch diameter tubes, arranged on a six inch diameter circle. These tubesheets were heated by Nichrome ribbon elements placed around the rim, as indicated in Figure 4-2, until a thermocouple in the core indicated a predetermined temperature level. A water spray was then automatically turned on, and the welds, risers and a short section of the attached tubing were rapidly cooled to a preset low temperature. At this point, the spray automatically turned off, and the tubesheet temperature was brought up again to the original high temperature, where another cooling cycle began.

The spray nozzle was located in a three inch opening at the bottom of the furnace insulation, and centered so that water covered the annular area between the inner wall of the insulation and the center conical deflector.

Subsequently, the cooling cycle was modified by eliminating the bottom spray, and replacing it with a direct flow of water piped into the top of each of the tubes. After each twenty five or fifty cycles, the test units were inspected for cracks using a dye penetrant check and a pressure test, as indicated in Figure 4-3.

The data taken consisted of continuous recordings of the temperature of the tubesheet mass, and either a weld temperature or a temperature a certain distance into the tube. The data were recorded on Leeds and Northrup strip chart controller-recorders. Typical heating and cooling cycle curves are shown in Figure 4-11 through 4-14.

\section{DESCRIPTION OF TEST UNITS}

The units tested consisted of the following:

1. One carbon steel tubesheet, twelve inches in diameter and three inches thick, with twelve tubes equally spaced and welded on the circumference of a six inch diameter circle. This sample tubesheet contained flush and trepanned-type tube-to-tubesheet connections, as well as expanded and nonexpanded tubes.

2. One $2-1 / 4 \%$ chromium $1 \%$ molybdenum steel tubesheet, into which six, two inch outside diameter, 0.220 inch wall boiler tubes were welded; all flush joints.

3. One 2-1/4\% chromium $1 \%$ molybdenum steel tubesheet, into which six, two inch outside diameter, 0.220 inch wall boiler tubes were welded; three tubes with flush joints, and three with trepanned risers. 


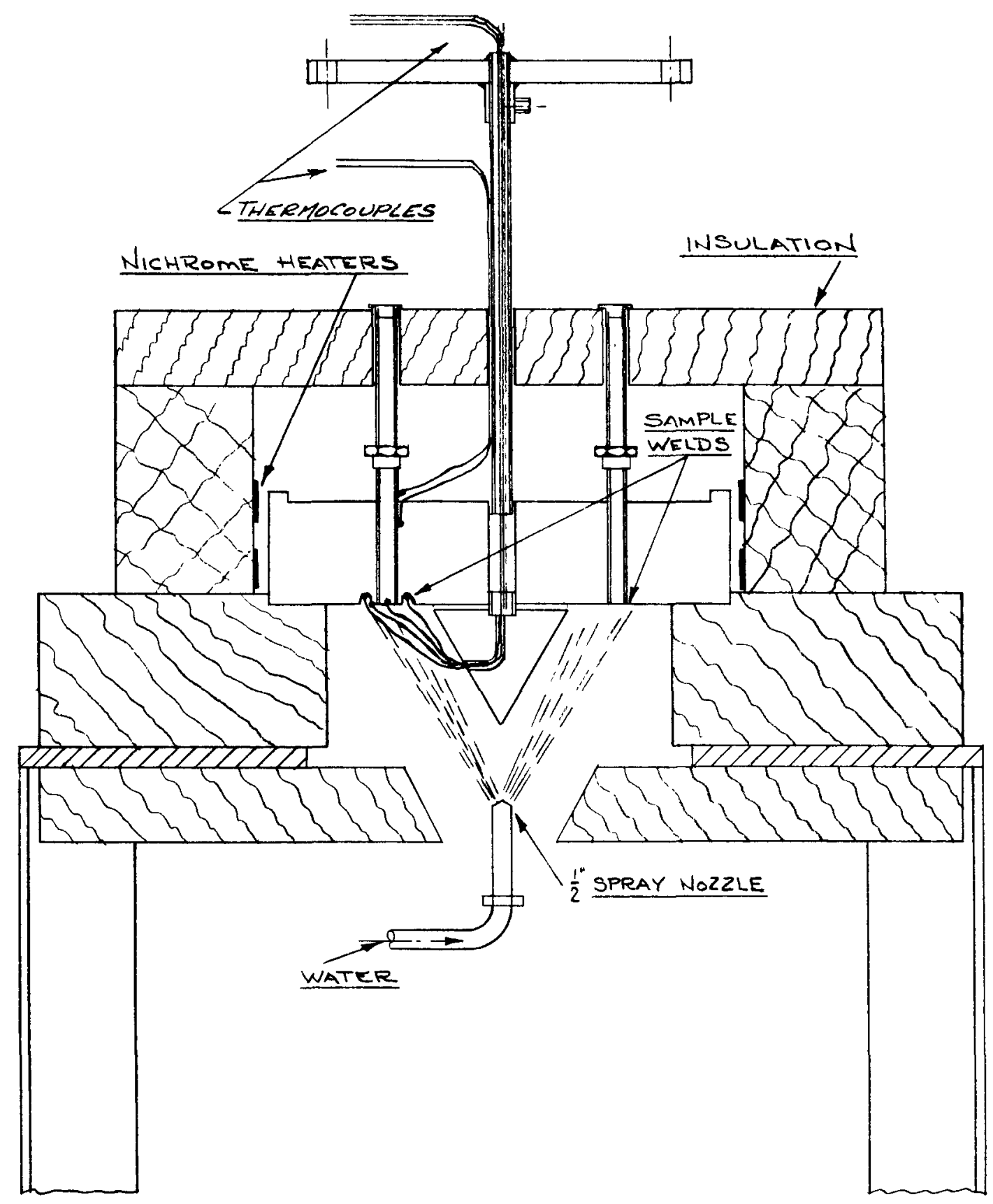

FIGURE 4-2 FURNACE ARRANGEMENT 


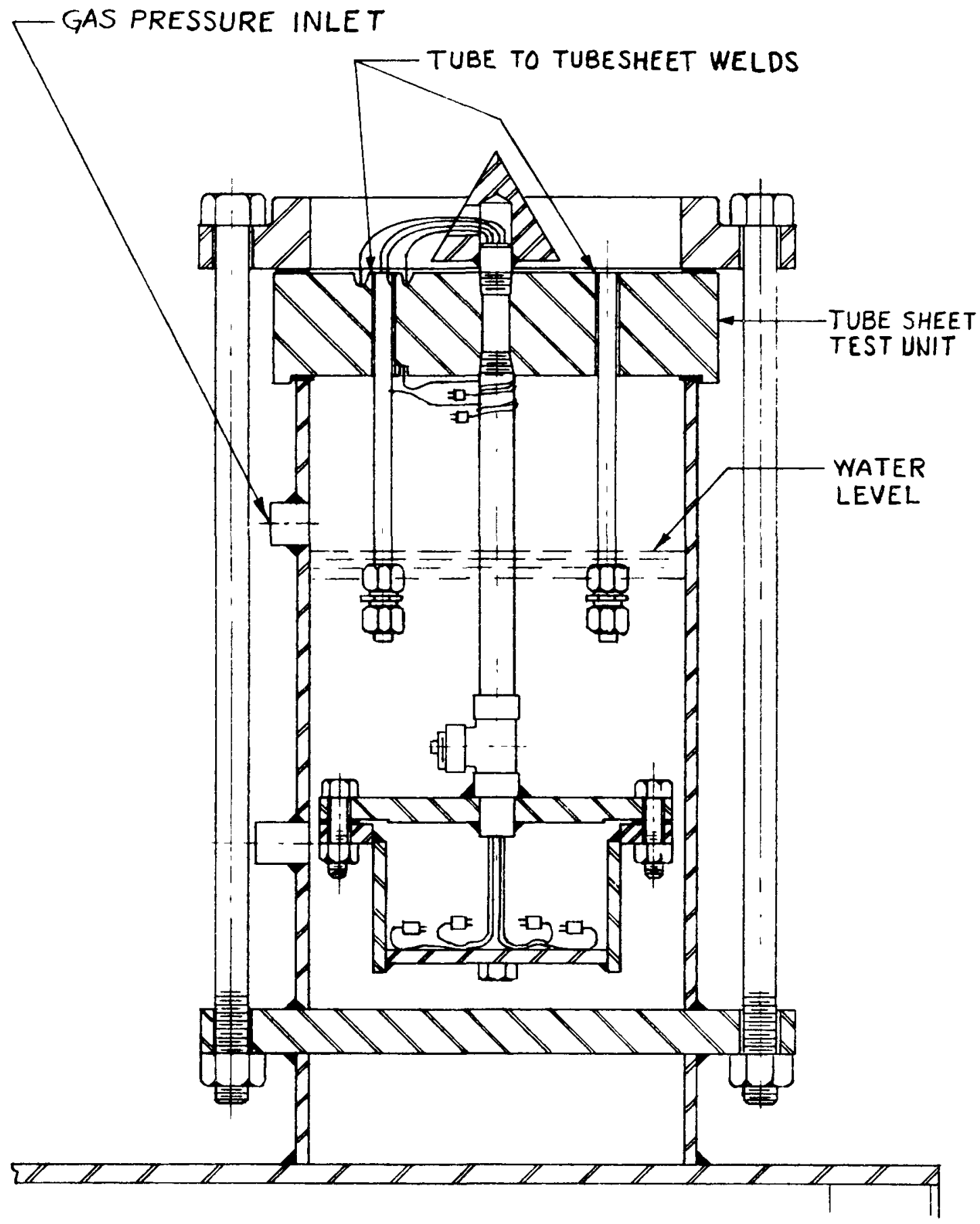

FIGURE 4-3 PRESSURE TEST ARRANGEMENT 
4. One stainless steel tubesheet, containing twelve, one half inch outside diameter, 0.049 inch wall stainless steel tubes; all flush joints.

5. One stainless steel tubesheet, containing twelve one half inch outside diameter, 0.083 inch wall stainless steel tubes all trepanned risers.

NOTE: Except for the carbon steel tubesheet in which the welds were flush with the surface of the tubesheet, all "flush" tube to tubesheet welds are actually fillet welds made to a flat tubesheet. The term "flush" is used to distinguish it from the trepanned joint.

\section{TEST EQUIPMENT}

The equipment used consisted of the necessary temperature controllers, recorders, thermocouples, a cycle counter, an ammeter and voltmeter, D.C. Generator, water nozzle, and a test rig. The test was set up so that it could be run automatically and unattended. A photograph of the furnace arrangement, pressure test cylinder and control board is shown in Figure 4-1.

\section{PROCEDURE FOR TEST UNIT NUMBER ONE CARBON STEEL TUBESHEET}

While no carbon steel has been selected for construction of the boiler or heat exchanger, a carbon steel tubesheet was prepared from available material to expedite the test program.

This unit was tested to establish conditions for the subsequent tests such as location of thermocouples, temperature distribution, nozzle position and other pertinent variables and not to evaluate the tube to tubesheet weld joint design.

The test was programmed with the aid of two controllers and two recorders. One mass thermocouple was connected to a controller, and used to regulate the power to the Nichrome alloy heating element. When the tubesheet mass reached a predetermined temperature, the power would shut off and remain off until the temperature dropped below this level.

One flush joint thermocouple was connected to the other controller, and was used to regulate the water spray on the tubesheet. When the flush joint temperature reached a predetermined level, the controller automatically 
actuated a relay and caused the water spraying to start. When the flush joint reached the lower temperature, the controller again actuated the relay and the water spray stopped.

The two recorders were also used to record the temperature of the remaining thermocouples as illustrated in Figure 4-4. One thermocouple was attached to each recorder, and the tubesheet was put through a few spraying cycles. These two thermocouples were then disconnected from the recorders, and two more connected, until all the temperatures had been recorded.

The tubesheet was heated to $750^{\circ} \mathrm{F}$ and cooled to $250^{\circ} \mathrm{F}$, with data being recorded as described above. The tubesheet was then rotated one quadrant and the above was repeated. Changes were made in the nozzle position and height during these tests until equal temperature drops were obtained for all quadrants.

When even cooling was obtained, the tubesheet was put through a complete test (including pressure checking after each group of cycles), as indicated in Table 4-1.

TABLE 4-1

CARBON STEEL TUBESHEET CYCLE TEST

\section{Test Cycle}

Heat to $750^{\circ} \mathrm{F}$ and cool to $250^{\circ} \mathrm{F}$ Heat to $850^{\circ} \mathrm{F}$ and cool to $250^{\circ} \mathrm{F}$ Heat to $950^{\circ} \mathrm{F}$ and cool to $250^{\circ} \mathrm{F}$ Heat to $1050^{\circ} \mathrm{F}$ and cool to $250^{\circ} \mathrm{F}$ Heat to $1150^{\circ} \mathrm{F}$ and cool to $250^{\circ} \mathrm{F}$

\author{
Water Spray, Time
}

$$
\begin{aligned}
& 18-20 \text { seconds } \\
& 10-16 \text { seconds } \\
& 17-20 \text { seconds } \\
& 25-30 \text { seconds } \\
& 25-30 \text { seconds }
\end{aligned}
$$

Number of Cycles

$$
\begin{gathered}
25+25+50 \\
25+25+50 \\
25 \\
25 \\
25
\end{gathered}
$$

The observed temperature ranges at difference points in the tubesheet during these cycles are given in Table 4-2. The location of the thermocouples is shown in Figure 4-4. 
TABLE 4-2

THERMOCOUPLE DATA

CARBON STEEL TUBESHEET

Thermocouple

Position

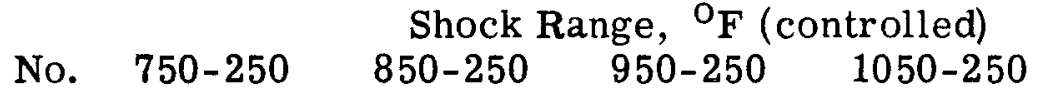

$1150-250$

(SprayTime - $18-20 \mathrm{sec} \quad 10-16 \mathrm{sec}$. $17-20 \mathrm{sec}$ 25-30 sec. $25-30 \mathrm{sec}$ )

\begin{tabular}{|c|c|c|c|c|c|c|}
\hline Trepan & 1 & $770-240$ & $875-240$ & $975-245$ & $1080-260$ & \\
\hline Trepan & 2 & $740-370$ & $840-450$ & $945-484$ & $1050-610$ & $1150-260$ \\
\hline Weld & 3 & $780-205$ & $825-205$ & $930-210$ & $1030-205$ & \\
\hline Weld & 4 & $750-255$ & $845-255$ & $945-255$ & $1045-255$ & $1130-255$ \\
\hline Trepan & 5 & $760-230$ & $875-310$ & $980-305$ & $1070-345$ & \\
\hline Trepan & 6 & $735-270$ & $850-640$ & $950-565$ & $1045-485$ & $1145-620$ \\
\hline Weld & 7 & $735-210$ & $835-210$ & $935-210$ & $1015-205$ & $1125-205$ \\
\hline \multirow[t]{2}{*}{ Weld } & 8 & $770-230$ & $850-285$ & $945-275$ & $1020-240$ & $1150-285$ \\
\hline & 9 & & & & & \\
\hline Core & 10 & & $865-845$ & $975-940$ & $1075-1020$ & \\
\hline Core & 11 & & $875-855$ & $975-935$ & $1065-995$ & \\
\hline Core & 12 & & $880-860$ & $975-940$ & $1055-1000$ & \\
\hline Tube beyond tubesheet & 13 & & $940-895$ & $1050-980$ & $1145-1015$ & \\
\hline Tube beyond tubesheet & 14 & & $630-610$ & & & \\
\hline Tube beyond tubesheet & 15 & & $935-885$ & $1025-950$ & $1105-970$ & \\
\hline Tube beyond tubesheet & 16 & & $935-885$ & $1020-940$ & $1085-965$ & \\
\hline Core & 17 & & & & & \\
\hline Core & 18 & $730-715$ & $855-840$ & $935-915$ & $1050-1005$ & $1165-1120$ \\
\hline Core & 19 & & & & & \\
\hline $1 / 4$ inch up in tube & 20 & $740-215$ & $840-220$ & $945-215$ & $1045-215$ & \\
\hline $1 / 4$ inch up in tube & 21 & $740-215$ & $840-290$ & $940-295$ & & \\
\hline $1 / 4$ inch up in tube & 22 & $730-210$ & $825-210$ & $925-210$ & $1020-205$ & \\
\hline $1 / 4$ inch up in tube & 23 & $720-195$ & $850-240$ & $940-230$ & $1025-210$ & \\
\hline
\end{tabular}



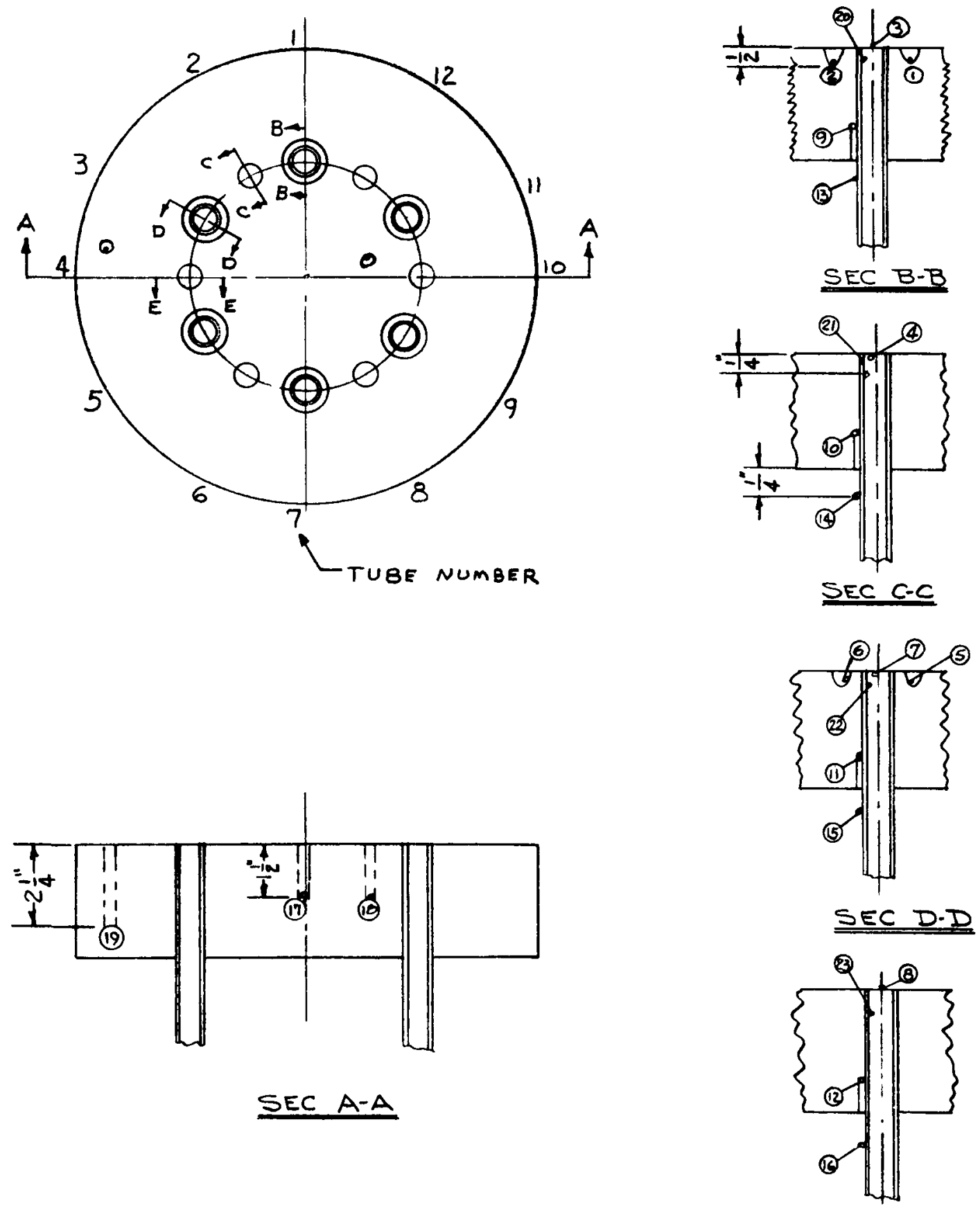

SEC E-E

FIGURE 4-4 THERMOCOUPLE LOCATIONS - CARBON STEEL TUBESHEET 


\section{RESULTS OF CARBON STEEL TUBESHEET TESTS}

Failures in the carbon steel tubesheet were as follows:

1. A small pin hole was found in the weld around tube one (an expanded trepanned joint. It is believed that this was due to porosity in the weld, and not to the heating and quenching. As the testing continued, this pin hole sealed itself and stopped leaking.

2. A similar pin hole was found around tube six (an expanded flush joint). This hole was larger than the one around tube one, and was also believed to be due to porosity in the weld and not the heating and quenching. This pin hole did not seal itself.

3. After heating and quenching at $950^{\circ} \mathrm{F}$, an " $L "$ "-shaped crack was found at tube two (an expanded flush joint). With the aid of pressure checking and dye-checking, this crack appeared as a definite failure, and not as a pin hole in the weld. As testing continued, the crack appeared to be incerasing in size.

In spite of the stress concentrations which would result from the connecting pin holes present in tube welds one and six, neither one of these welds showed further damage during the thermal stressing.

Figure 4-5 and 4-6 show the cracks which developed at tube two. Figure 4-7 shows the large blow hole which was found between these cracks. In spite of this large blow hole, leakage did not occur until after two hundred cycles of thermal stressing.

All three of these tubes were rolled before the welding was done. Apparently, the air trapped in the crevice expanded and forced its way through the liquid metal as the weld was being completed.

\section{TESTS UNITS TWO AND THREE}

2-1/4\% CHROMIUM-1\% MOL YBDENUM STEEL

These units were tested to simulate conditions in the boiler tubesheet. Figure 4-8 shows the tubesheet design and thermocouple locations.

The 2-1/4\% chromium-1\% molybdenum steel tubesheets, containing six two inch diameter tubes, 0.220 inch wall, were heated and cooled as indicated in Tables 4-3 and 4-4. 


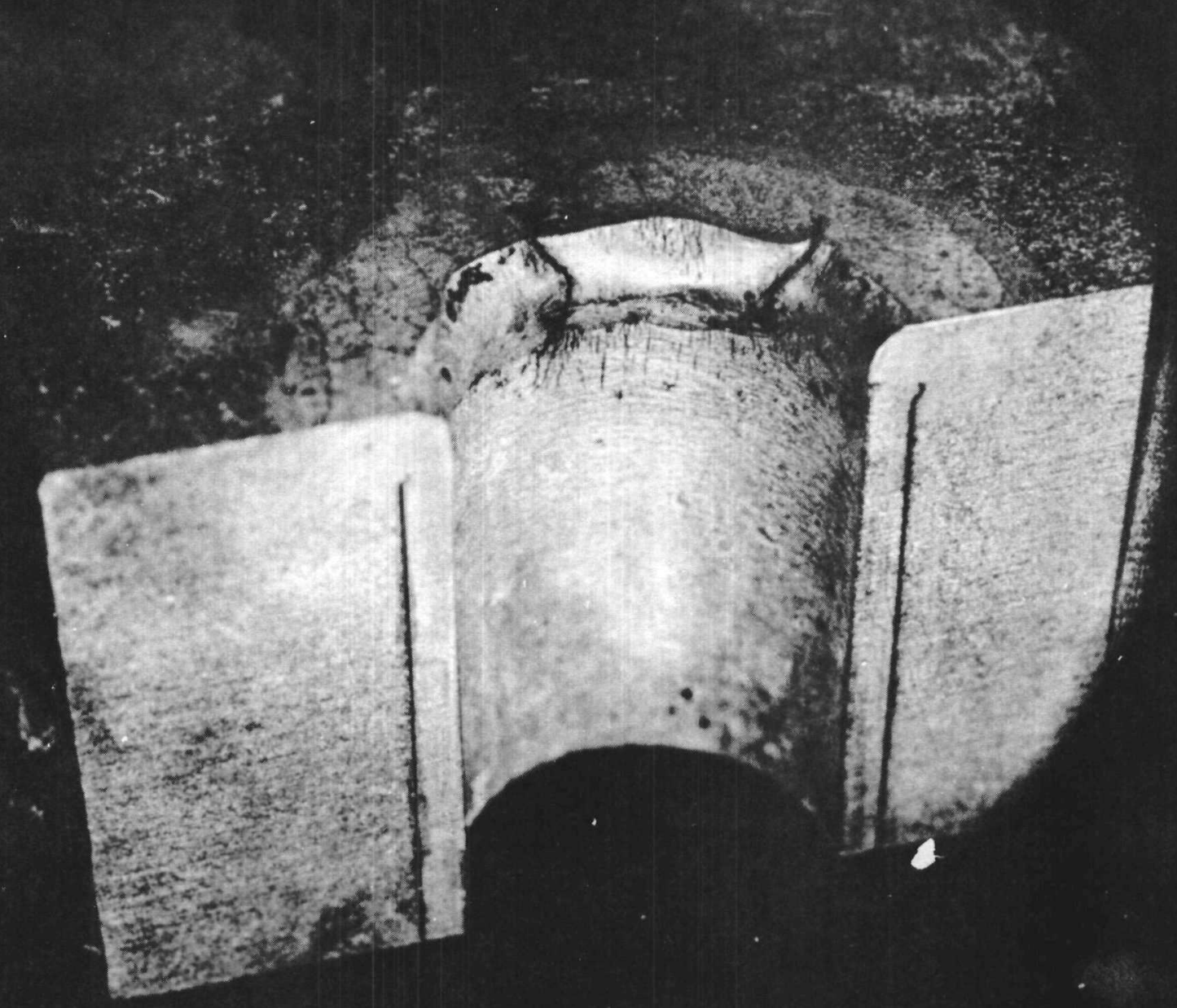

FIGURE 4-5

CRACKS IN FLUSH WELD CARBON STEEL TUBESHEET 


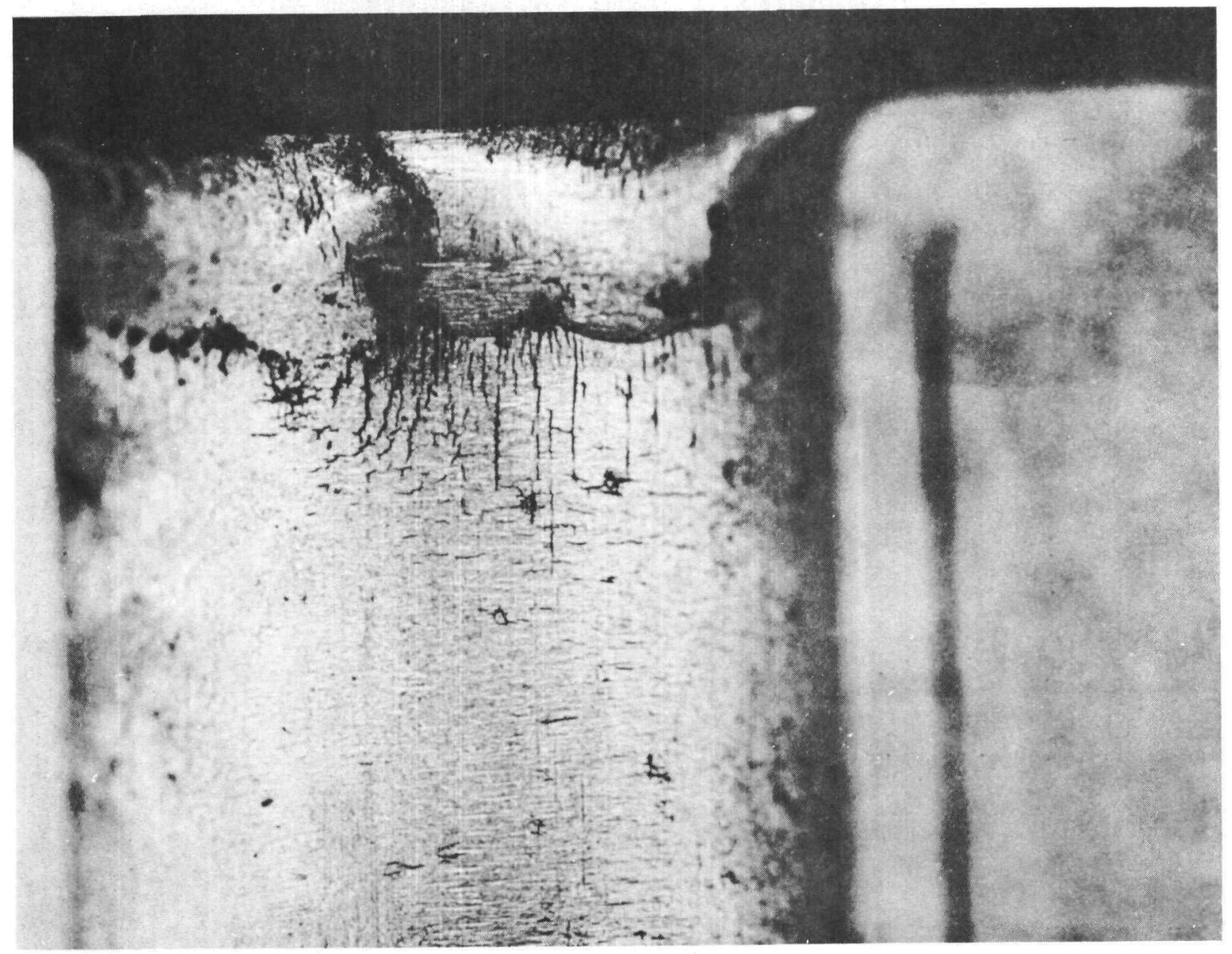

F IGURE 4-6

CLOSE-UP VIEW OF CRACKS IN FLUSH WELD

CARBON STEEL TUBESHEET 


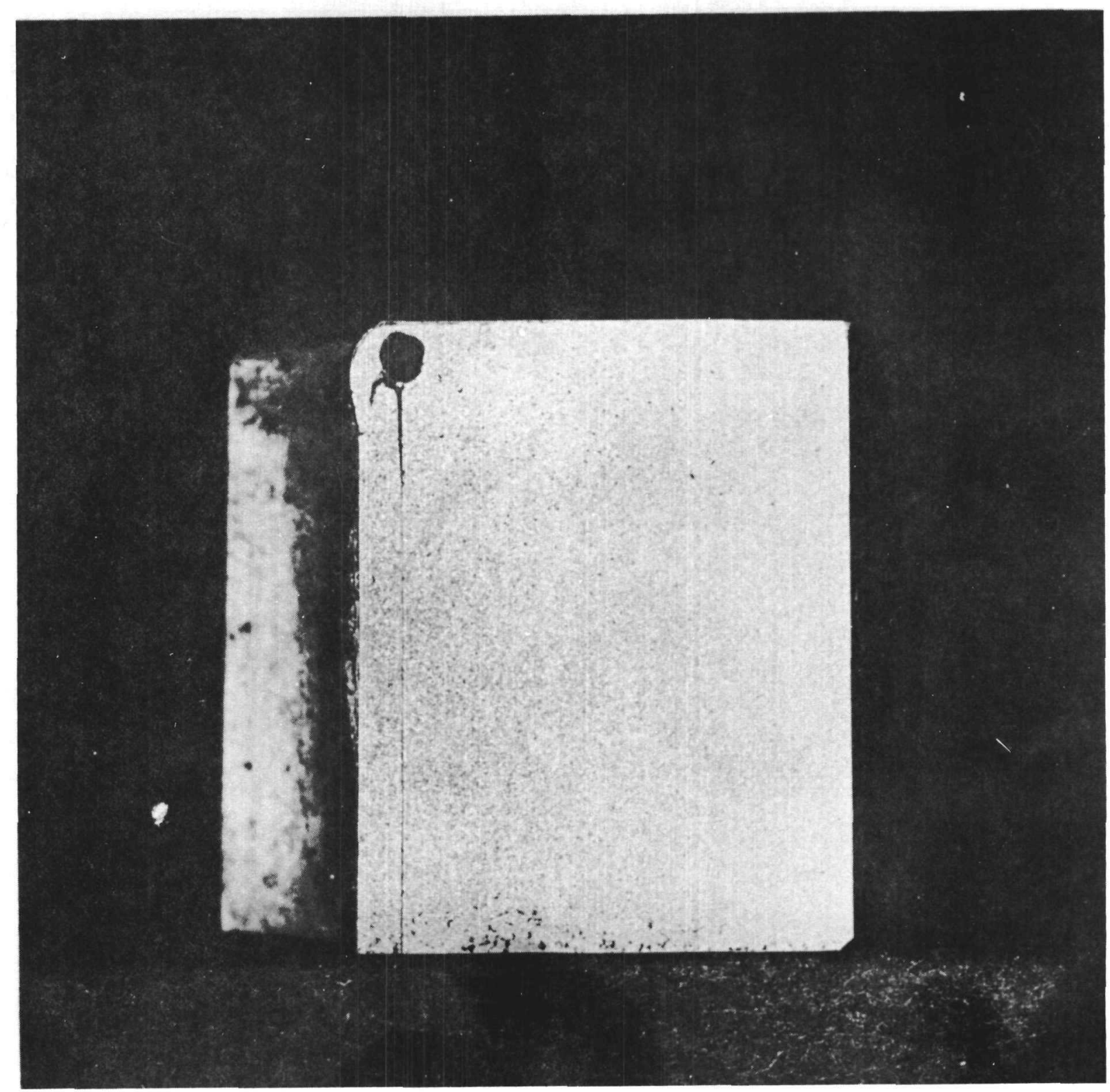

F IGURE 4-7

AIR BUBBLE ACCOUNTING FOR FAILURE OF ONLY WELD WHICH CRACKED DUE TO THERMAL STRESSES - CARBON STEEL TUBESHEET 

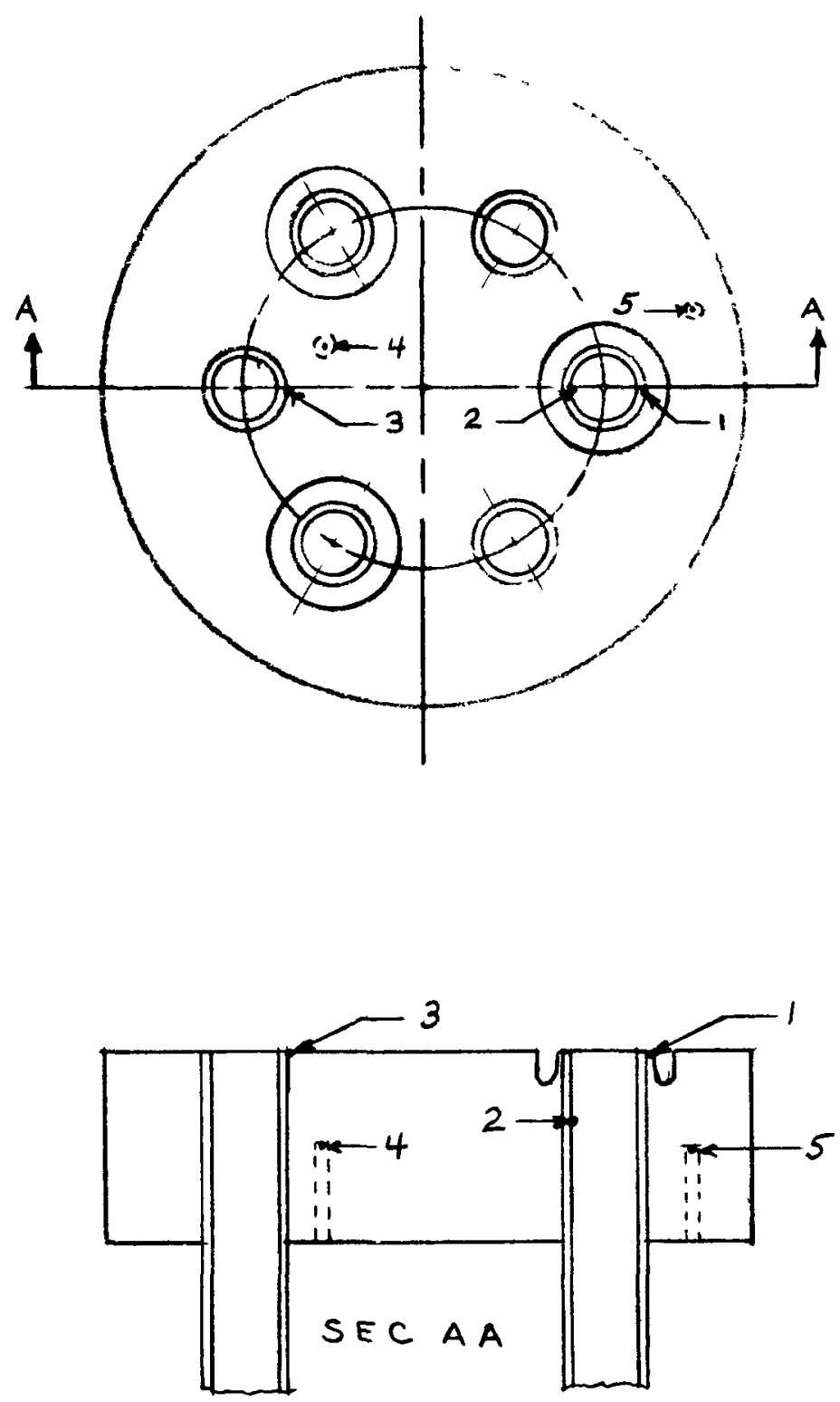

FIGURE 4-8 THERMOCOUPLE LOCATIONS - 2-1/4\% CHROMIUM STEEL TUBESHEET 
TABLE 4-3

2-1/4\% CHROMIUM STEEL TUBESHEET CYCLE TEST

(FLUSH JOINTS)

$\begin{array}{rc}\text { RANGE, }{ }^{\circ} \text { F } & \text { NUMBER OF CYCLES } \\ 650-250 & 25+25+50 \\ 750-250 & 25+25+50 \\ 850-250 & 25 \\ 950-250 & 25 \\ 1050-300 & 25\end{array}$

Total 275 cycles

TABLE 4-4

2-1/4\% CHROMIUM STEEL TUBESHEET CYCLE TEST (TREP ANNED JOINTS)

$\begin{array}{rr}\text { RANGE, }{ }^{\circ} \text { F } & \text { NUMBER OF CYCLES } \\ 650-250 & 25 \\ 650-300 & 25 \\ 1050-300 & 25 \\ 1050-300 & 25\end{array}$

Total 100 cycles

Figure 4-9 shows a typical heating and cooling cycle curve with the control thermocouple at a weld, and at a point inside the tube.

\section{RESULTS OF 2-1/4\% CHROMJUM-1\% MOL YBDENUM STEEL TUBESHEET TESTS}

For the first twenty five cycles with unit number two, the lower limit control thermocouple was placed on the upper face of one of the tube welds. It cooled from 640 to $320^{\circ} \mathrm{F}$ in six seconds, and from 320 to $250^{\circ} \mathrm{F}$ in another seven seconds, whereupon the water spray shut off, and reheating began. For the remaining cycles with this unit and for all the cycles for unit number three, the lower limit control thermocouple was located inside one of the tubes three quarters inch away from the weld. The metal at this point was much less rapidly cooled, so that the water spray remained on for eighty five to ninety seconds for unit number two and one hundred thirty seconds for unit number three. 


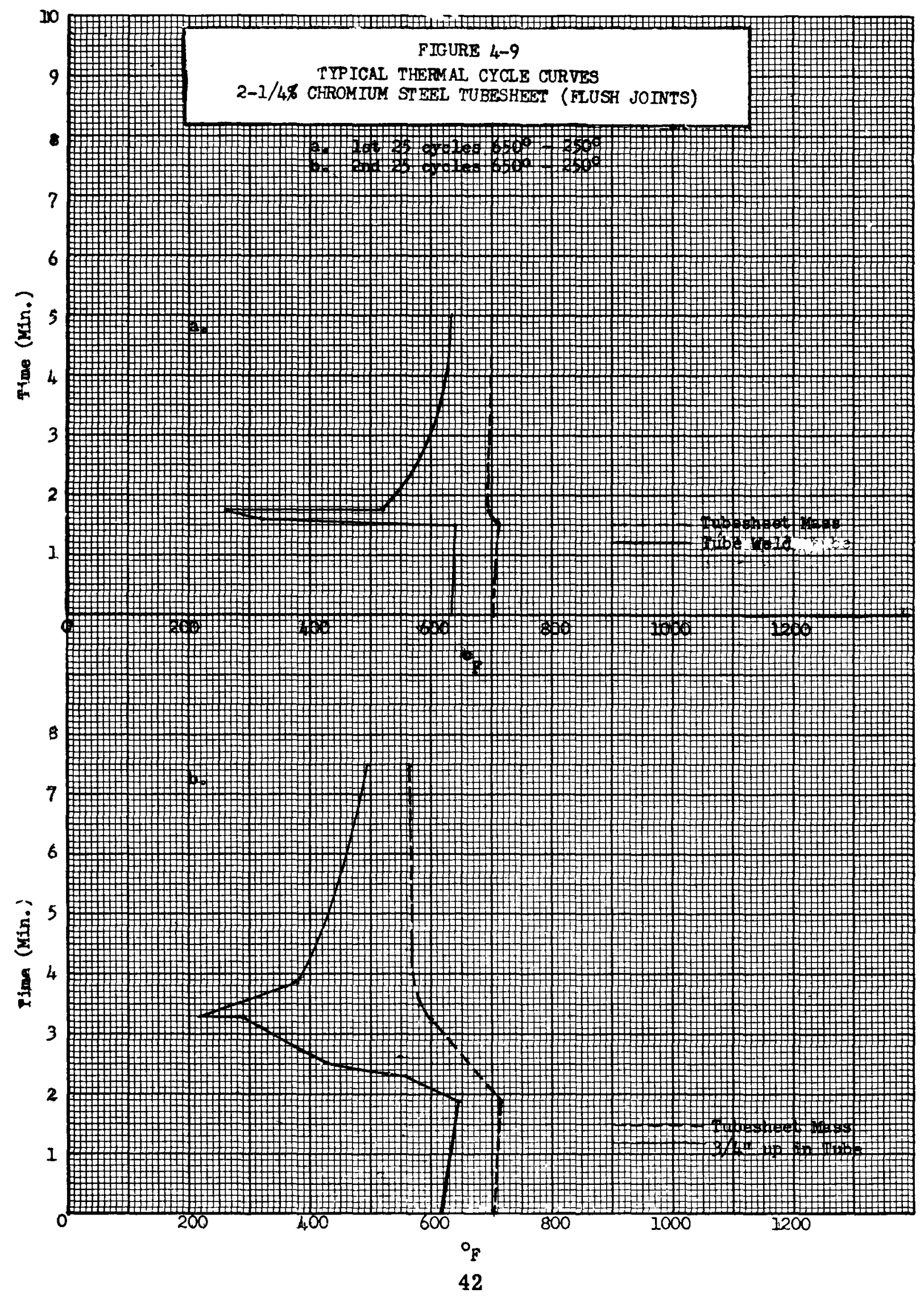


Due to the very high rates of cooling at the top surface, which was dir ectly hit by the water, surface stresses in the metal reached a probable $100,000 \mathrm{psi}$ for the 650 to $250^{\circ} \mathrm{F}$ range, and $180,000 \mathrm{psi}$ for the 1050 to $300^{\circ} \mathrm{F}$ range. This is larger than wo'ld be expected to occur in the actual boiler tubesheet. Due to the lower rate of cooling at thr ee quarters inch up the tube, the bending stress in the tube walls would be lower than possible peak values in the actual boiler tubes. The peak values referred to are those which would occur only during a rapid loss of boiler pressure, which represents a casualty, rather than a normal occurrence. The thermal stresses developed during these tests are higher than would normally be expected.

No cracks, leaks or other damage whatever were found by inspection during these runs.

TEST UNITS FOUR AND FIVE TYPE 316 STAINLESS STEEL

These units were tested to simulate conditions in the intermediate heat exchanger and superheater tubesheets. Figure 4-10 shows the tubesheet design, and thermocouple locations.

The stainless steel tubesheets, containing twelve, one half inch diameter tubes, 0.049 inch wall, were heated and cooled as indicated in Tables 4-5 and 4-6.

Figures 4-11 through 4-14 show typical heating and cooling cycle curves for the stainless steel tubesheets with flush joints and trepanned joints, and with spray cooling and direct water cooling.

TABLE 4-5

STAINLESS STEEL TUBESHEET CYCLE TEST (FLUSH JOINTS)

RANGE, ${ }^{\circ} \mathrm{F}$

$1150-650$.

$1150-250$

$1150-300$

$1150-400$
NUMBER OF CYCLES<smiles>[10BH2][10BH2-]</smiles>

189 cycles

During the last sixty four cycles, shocking was accomplished by a direct flow of water through the tubes, rather than by a water spray from below. 

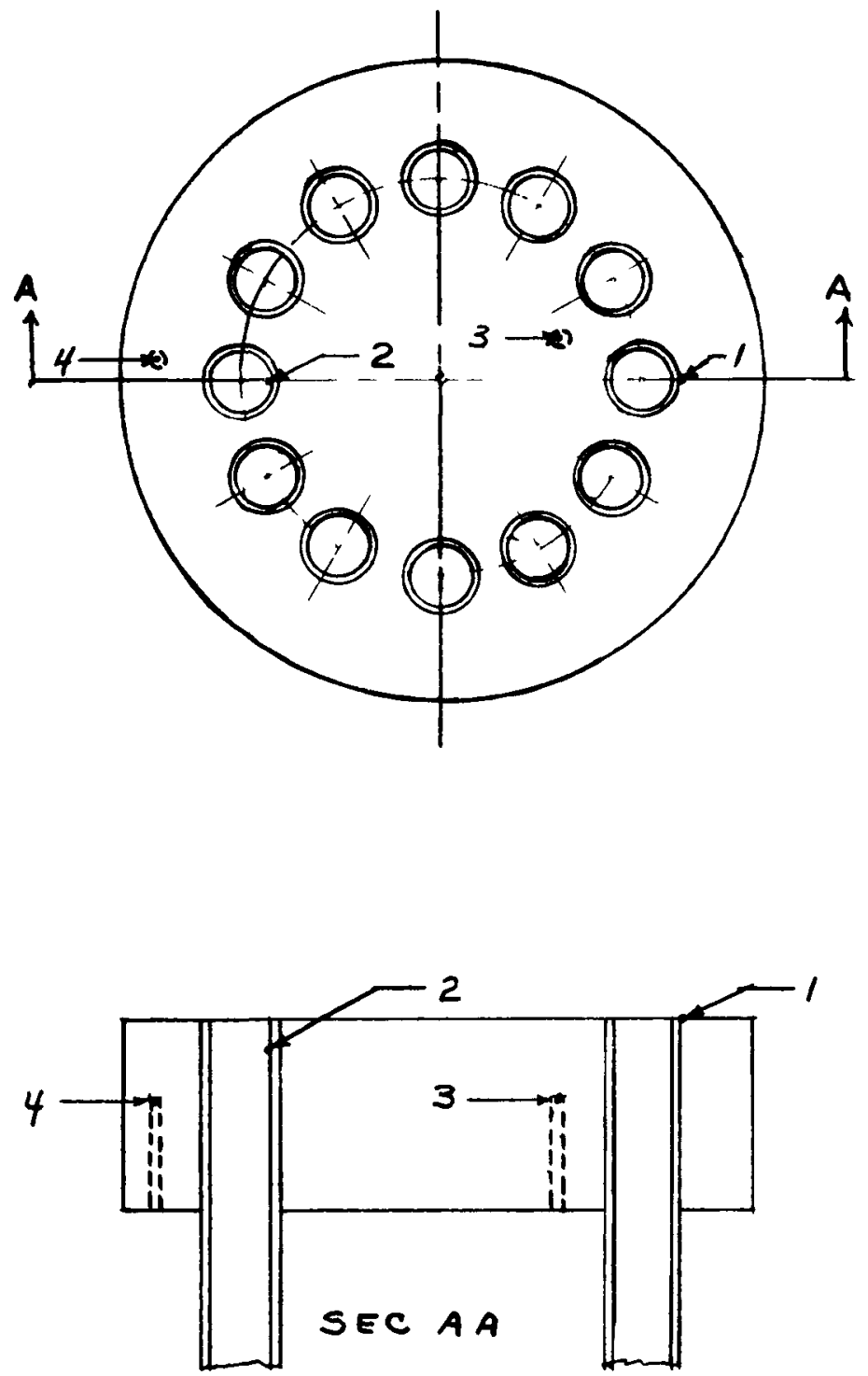

FIGURE 4-10 THERMOCOUPLE LOCATIONS - TYPE 316 STAINLESS STEEL TUBESHEET 


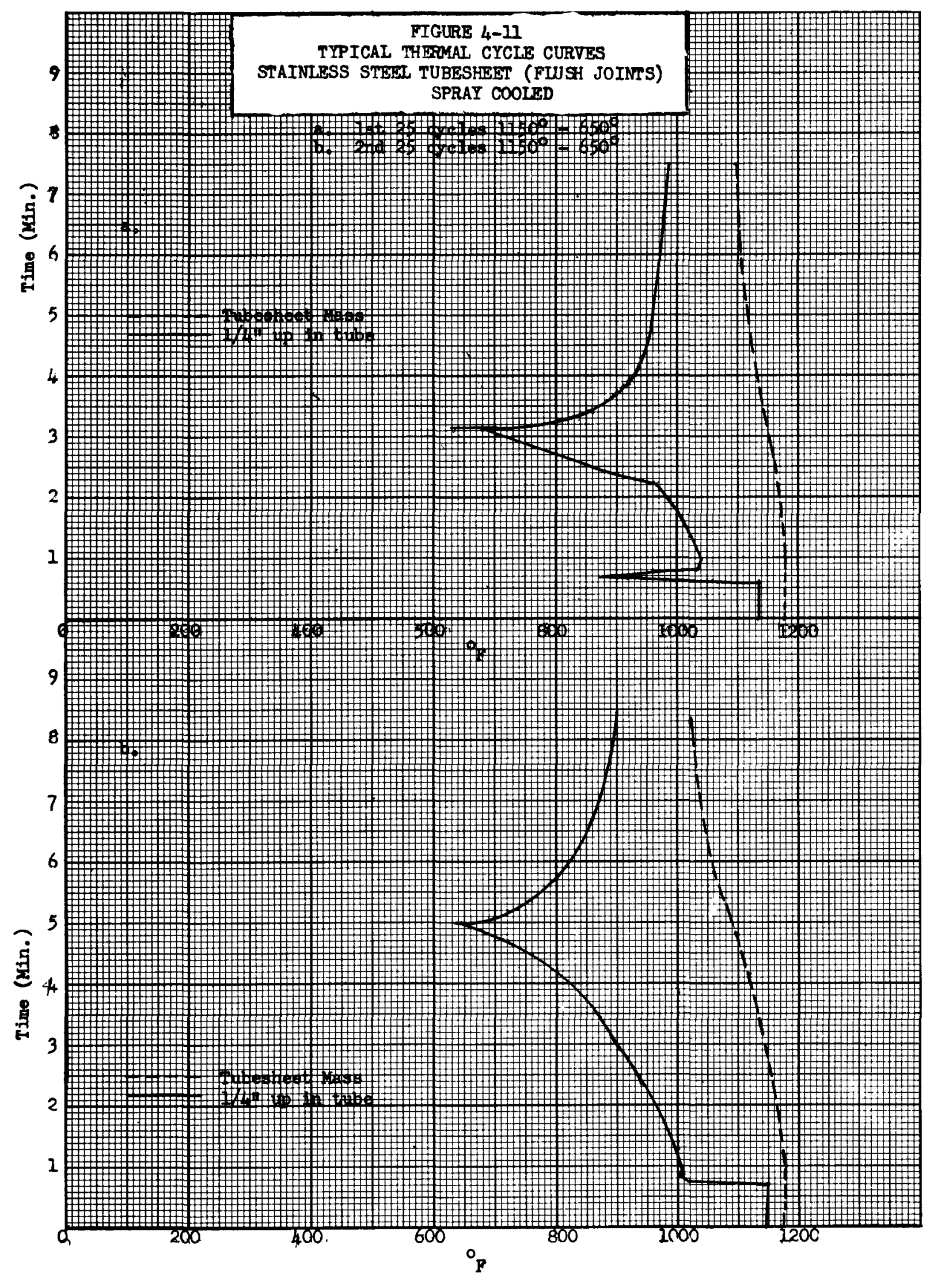




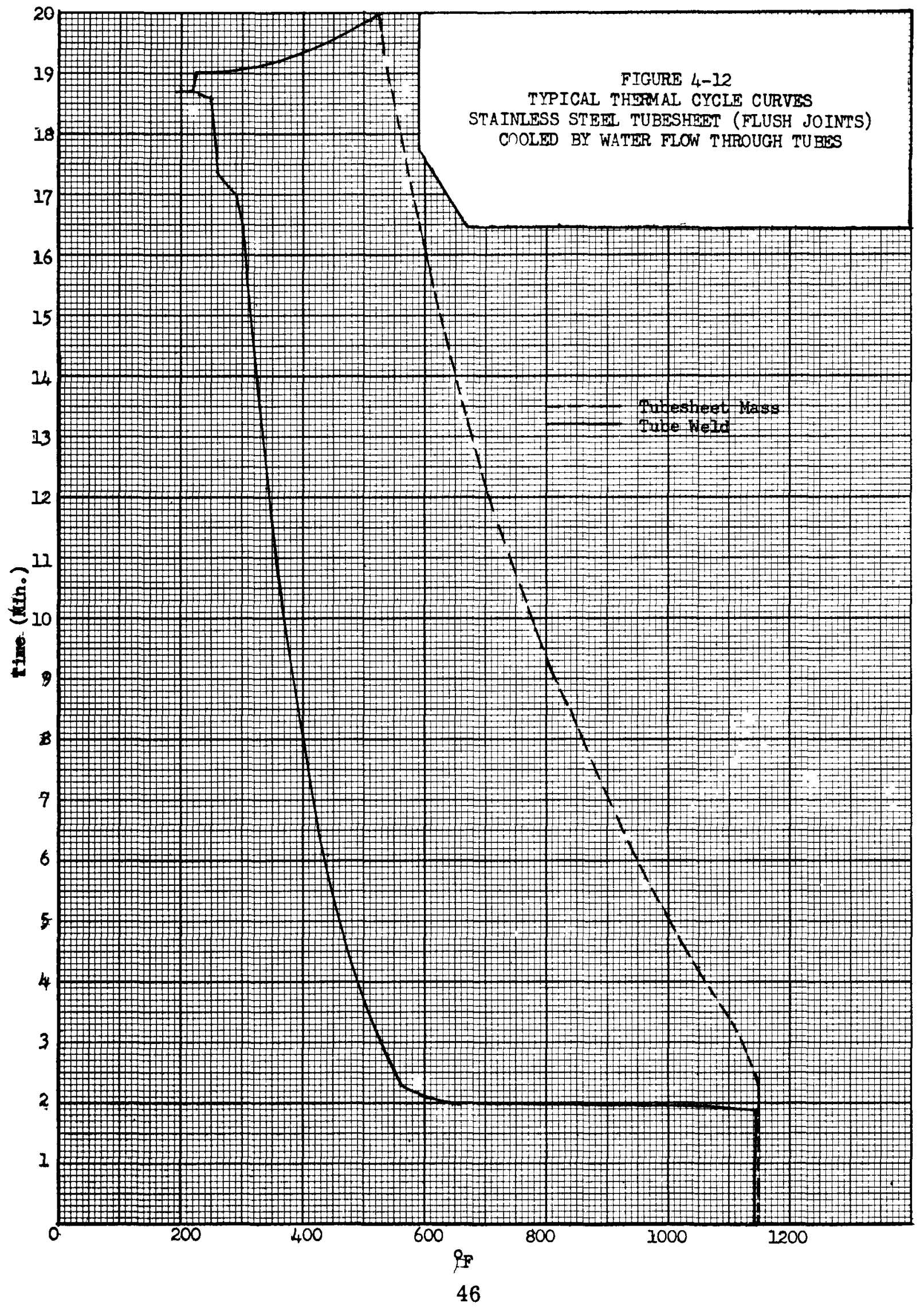




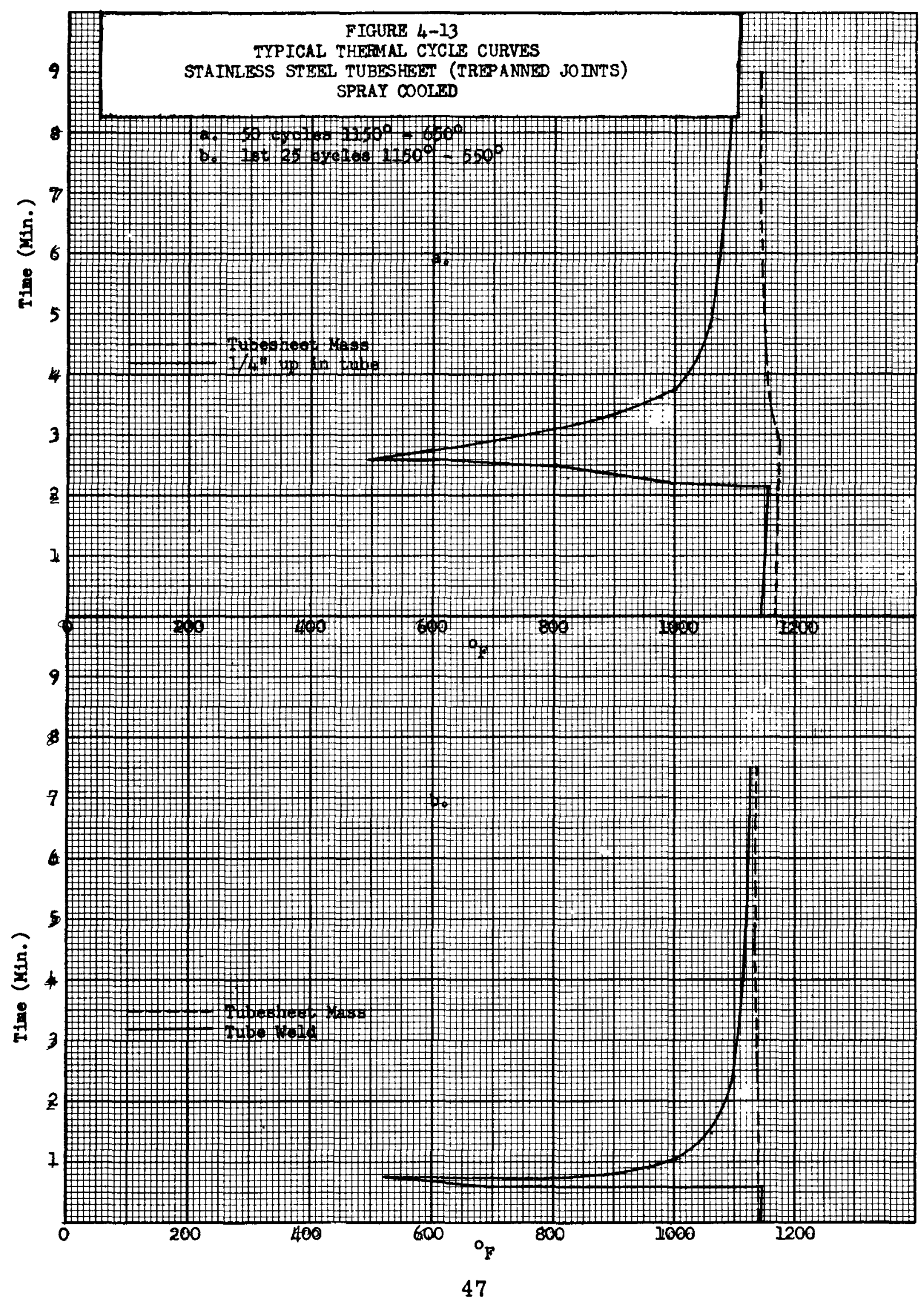




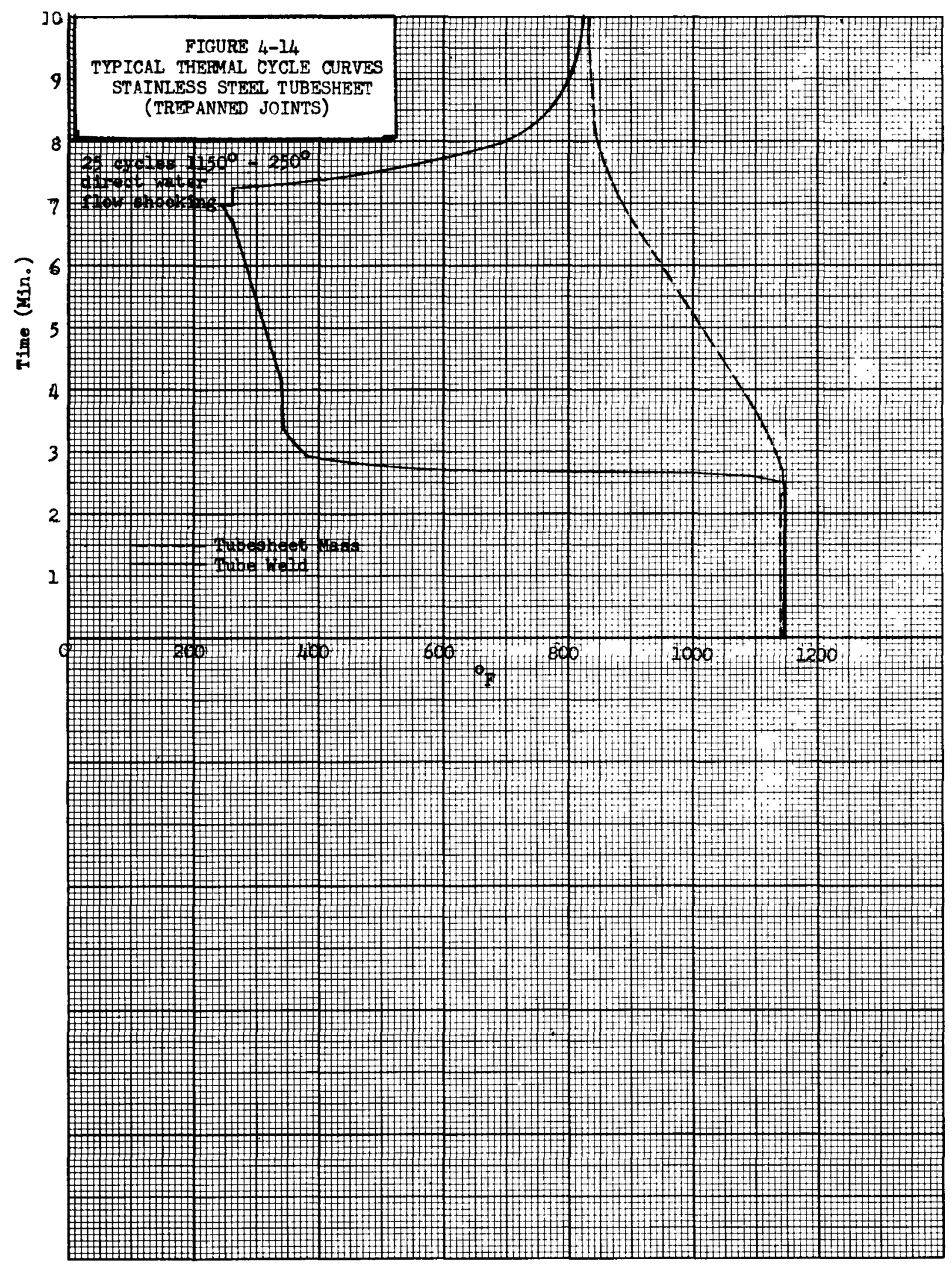


TABLE 4-6

STAINLESS STEEL TUBESHEET CYCLE TEST

(TREP ANNED JOINTS)

RANGE, ${ }^{\circ} \mathbf{F}$

$1085-650$

$1150-650$

$1150-550$

$1150-450$

$1150-250$
NUMBER OF CYCLES

$$
\begin{gathered}
25 \\
25+50 \\
25+25+50 \\
25 \\
25+25
\end{gathered}
$$

Total

275 cycles

During the last twenty five cycles, shocking was accomplished by a direct flow of water through the tubes, rather than a water spray from below.

Results of Type 316 Stainless Steel Tubesheet Tests

Much the same comments may be made regarding these units as regarding units two and three. The metal surface directly exposed to the water spray was cooled very rapidly from $1150^{\circ} \mathrm{F}$ to $250^{\circ} \mathrm{F}$ or $300^{\circ} \mathrm{F}$ during each cycle, resulting in computed surface thermal stresses of 200,000 to 300,000 psi. The lower limit control thermocouples were placed one quarter inch up inside the tubes and with flush welds, took two to four minutes to cool to the shut off temperature. With the trepanned riser welds, the thermocouple was within the riser section, and cooled down to the shut off temperature in thirty to sixty seconds.

With direct flow of water through the tubes, the first five hundred degrees of cooling in the flush welds occurred very rapidly (twelve seconds). In the trepanned riser welds, the first seven hundred fifty degrees of cooling occurred in twenty four seconds. Fur ther cooling in both cases was less rapid than by the spray method.

In these test units, the peak surface stresses were much higher than could occur in the actual units. For the flush welded units, the bending stresses during spray cooling were somewhat less severe, and during direct flow through the tubes, much more severe than peak values for actual service. With the trepanned riser welds, the bending stresses were in all cases equal to or more severe than peak values for actual service.

No cracks, leaks or other damage whatever were found by inspections during these runs. 


\section{METALLURGICAL INSPECTION}

Following the test runs, the test units were sectioned for metallurgical inspection.

Microexamination of the stainless steel tube-to-tubesheet weld joints after completion of thermal cycling revealed crevice corrosion between the tube and tubesheet in many of the joints examined. Some tubes were removed from the tubesheet for visual examination of the crevice area. General corrosion was evident in many of the joints, with iron oxide extending from the back side of the tubesheet up to the weld joint. The corrosion was not circumferentially uniform, and appeared to be due to the presence of moisture in areas of the joint.

The thermal cycle tests were conducted with a water quench on the face of the tubesheet away from the crevice. It was felt that moisture could not have penetrated to the back side of the tubesheet under testing conditions. However, a pressure test was applied to the back side of the tubesheet to test the welds prior to thermal cycling. Nitrogen pressure was applied over water to reduce the quantity of nitrogen needed. It was felt that moisture could have penetrated into the crevices during this test.

Intergranular corrosion extended from many areas of the crevice into the tube and/or tubesheet at many of the joints. Slight fissures also extended into several welds at the tip of the crevice, as shown in Figure 4-16, due to high stresses, plus crevice corrosion. The depth of intergranular penetration was greatest in the tube with flush welded joints. Intergranular cracks extended nearly across the tube in some of the more severely corroded areas, as shown in Figure 4-19. The favored direction of attack was reversed in the trepanned joints. Intergranular cracks extended across the tubesheet, as shown in Figure 4-18. Typical corroded specimens are shown in Figures 4-15 through 4-19.

The deepest penetration seemed to occur in the highly stressed area just below the base of the weld.

The direction of penetration was apparently influenced by the relative stresses in the tube and tubesheet. The stresses were apparently greatest in the tube for the flush joints, and greatest in the tubesheet for the trepanned joints. This tends to cast some doubt on the merit of the trepanned joint. In fairness to the trepanned design, it should be pointed out that the water spray cooled the tubesheet side of the joint at a greater rate than the tube side. This was in reverse to the cooling pattern which would occur in service. 
There was no apparent difference in degree of corrosion for flush joints in comparison with trepanned joints. Several joints of each type had very little corrosion. The significant factor in corrosion and intergranular cracking appeared to be the presence of moisture or other contaminants in the crevice during fabrication. On the basis of this observation, the use of water for hydrostatic testing, and use of cleaning fluids with water as the solvent, should be avoided on the shell side of the tubesheet. $\mathrm{Be}-$ fore finalizing this recommendation, additional testing is desirable to definitely ascertain the source of contaminants which initiated intergranular corrosion in the crevices. 


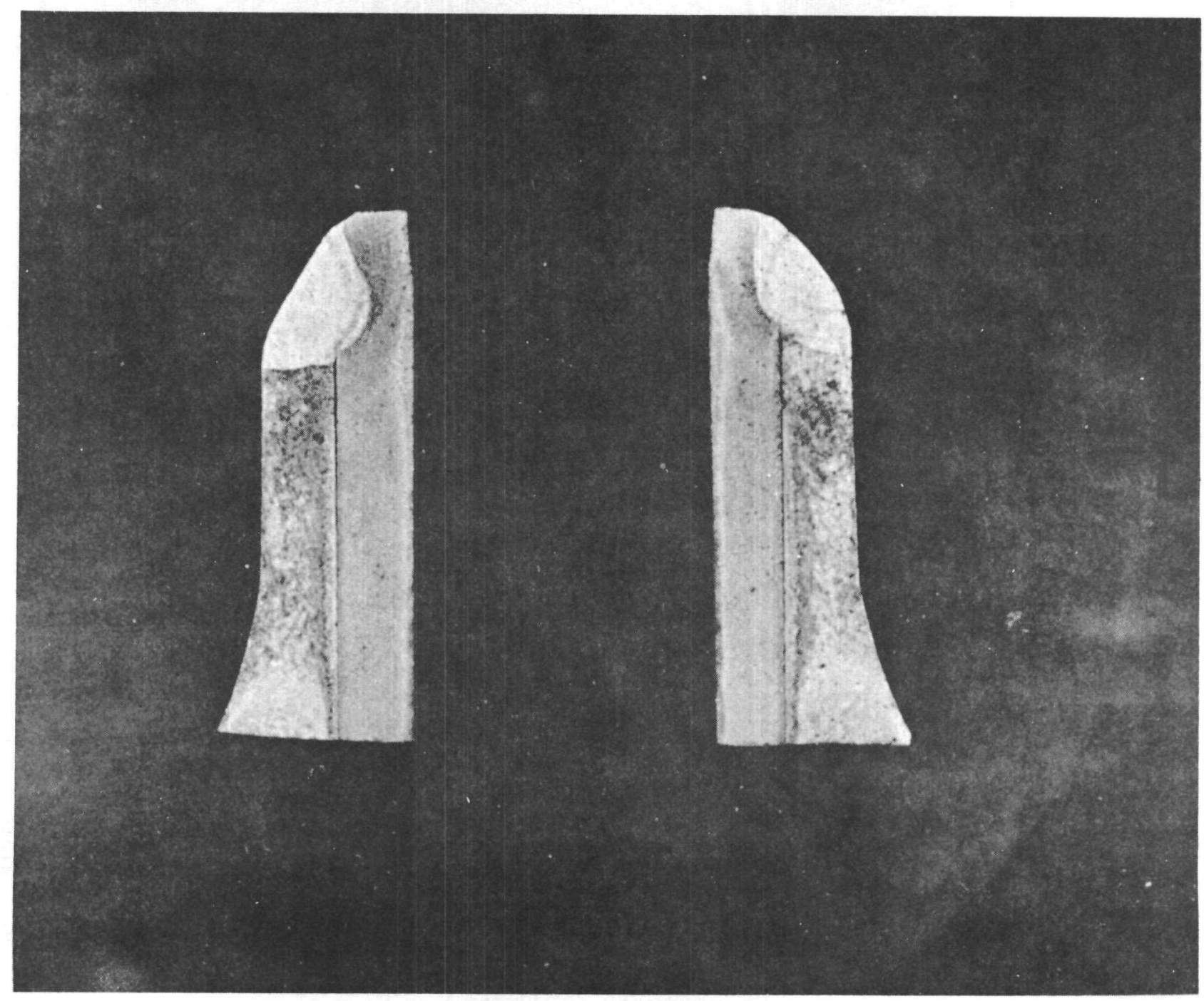

FIGURE 4-15 TRE-PANNED TUBE-TO-TUBE SHEET WELDED JOINT 


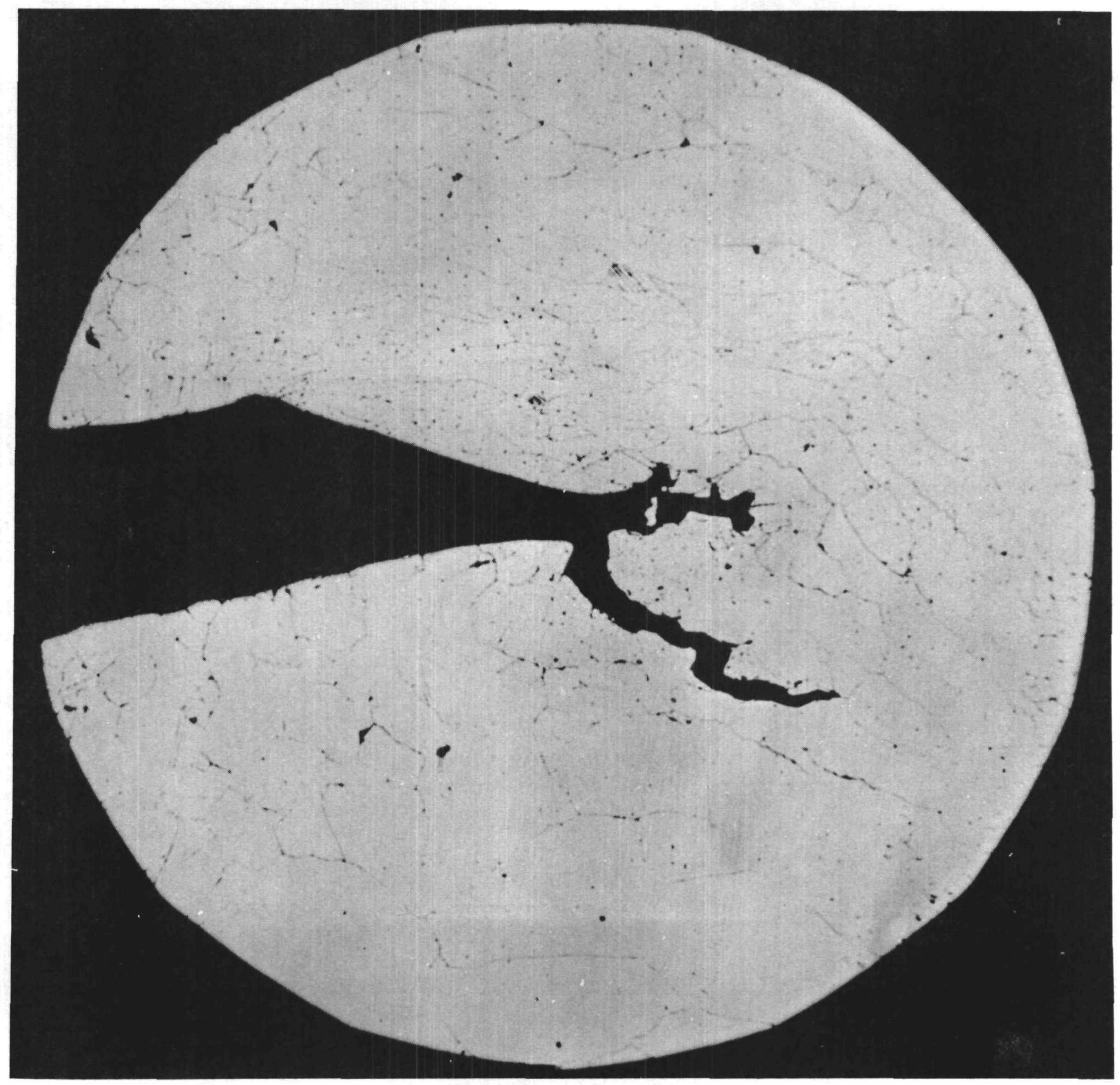

AISI 316 S.S.

Magnification 250X

FIGURE 4-16 FISSURE EXTENDING FROM CORRODED CREVICE INTO STRESSED WELD ZONE OF A TREP ANNED JOINT 

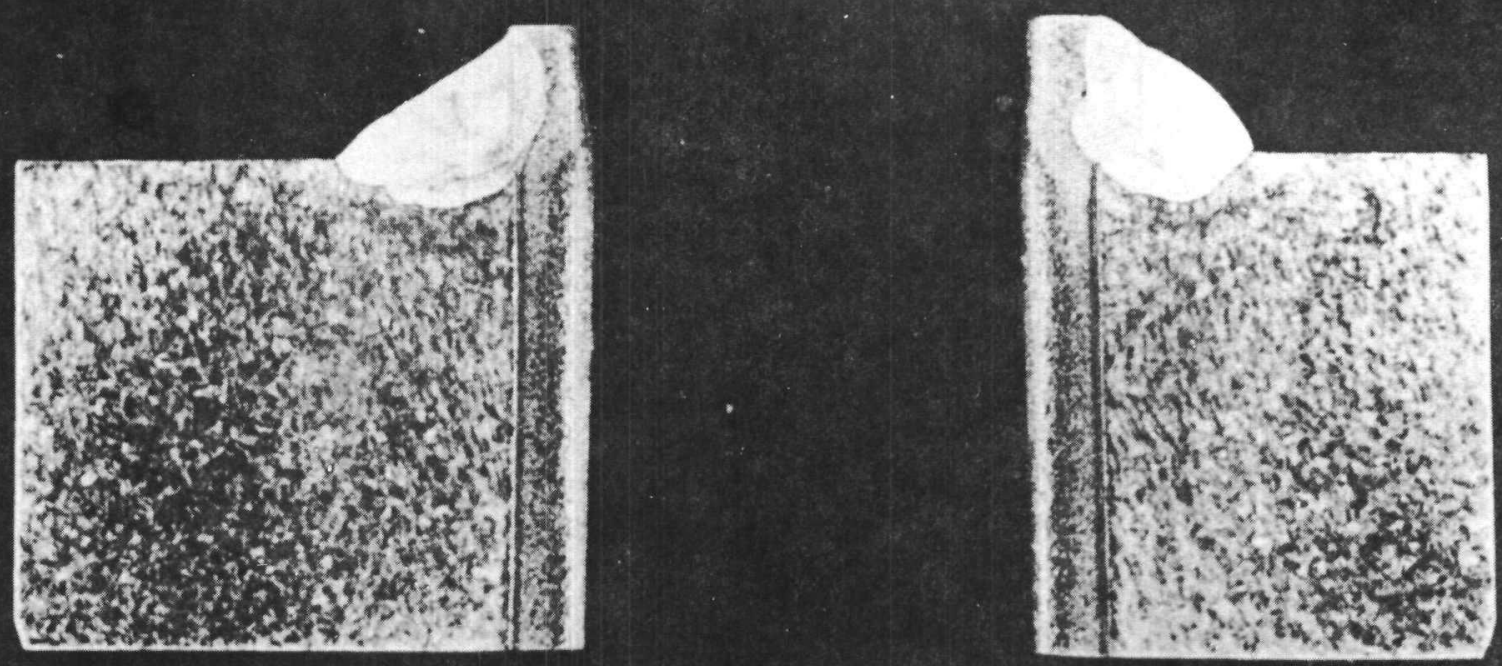


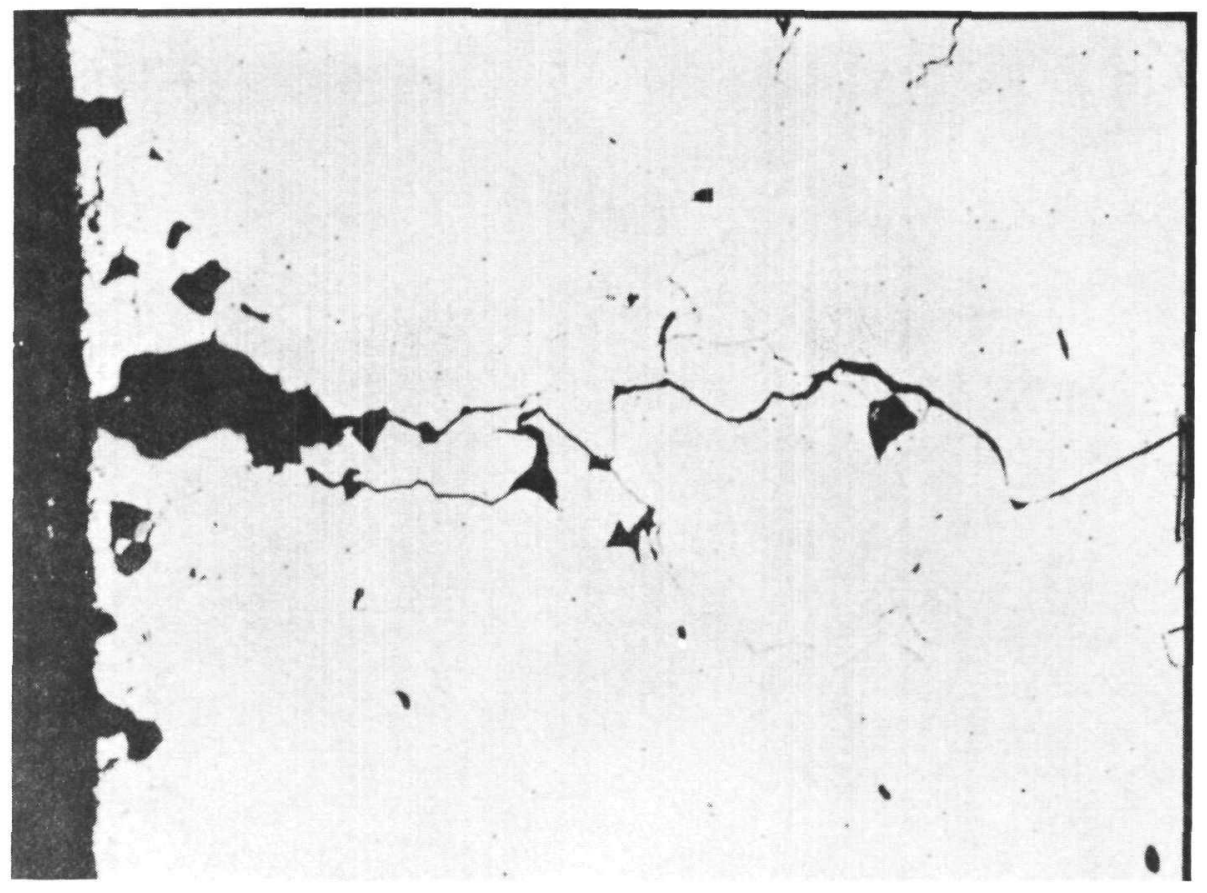

FIGURE 4-18 INTERGRANULAR CORROSION CRACK EXTENDING FROM THE CREVICE INTO THE TUBESHEET SIDE OF A TREPANNED JOINT AFTER THEMAL CYCLING

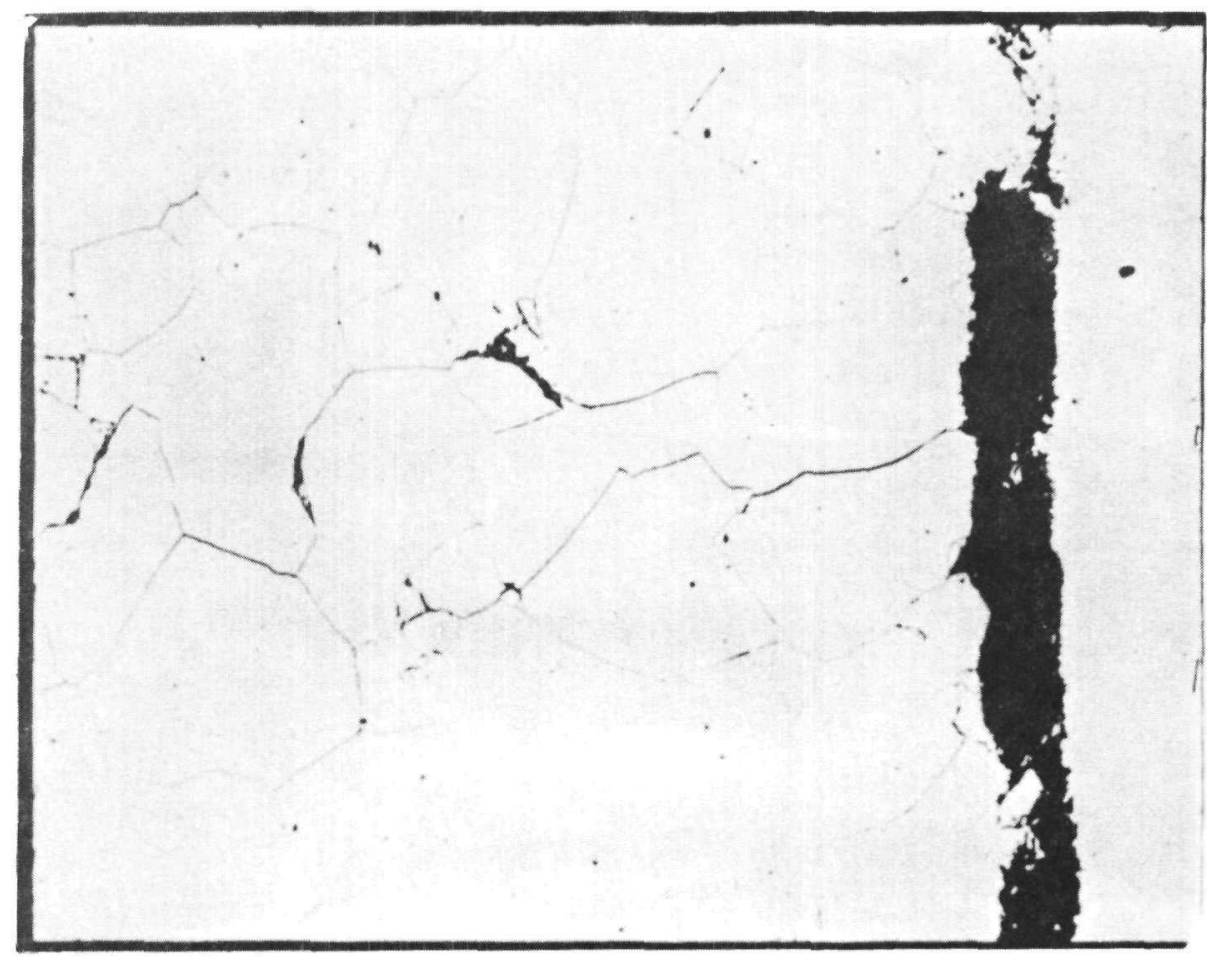

AISI $316 \mathrm{~S} . \mathrm{S}$. Magnification 250X

FIGURE 4-19 INTERGRANULAR CORROSION CRACK EXTENDING FROM THE CREVICE INTO THE TUBE SIDE OF A FLUSH WELDED JOINT AFTER THERMAL CYCLING 
-

○ 


\section{SECTION 5}

\section{METALLURGICAL EXAMINATION OF BIMETALLIC TUBES}




\section{METALLURGICAL EXAMINATION OF BIMETALLIC TUBES}

\section{TABLE OF CONTENTS}

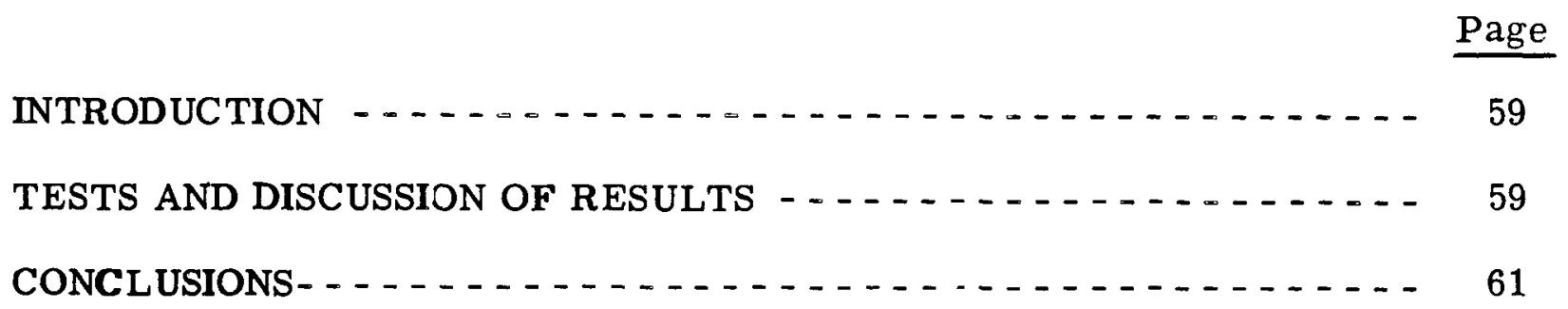




\section{INTRODUCTION}

Stress corrosion cracking is a major deterrent to successful performance of stainless steels in high temperature water and steam containing critical concentrations of caustic or chloride ions and oxygen. This condition is normally corrected by reducing the imposed and residual stresses in the stainless steel, as well as regulating the impurities in the water to a level that will not cause stress corrosion cracking. In view of the $1200^{\circ} \mathrm{F}$ and 2200 psia design requirements for the superheater of the Sodium Components Design Project, Type 316 stainless steel was selected as the optimum material for this application. Since an intricate water purity control system is not recommended for the superheater, the stainless steel must be shielded from the high temperature water and steam by a material that is not susceptible to stress corrosion cracking. The Type 316 stainless steel tubing must, therefore, be clad with a high-nickel alloy, preferably Inconel, on the inner wall to act as a barrier metal to the corrosive media.

Several tube manufacturers were contacted concerning the feasibility of producing bimetallic tubing of the above configuration. Few manufacturers have had previous experience with this particular design, but several tube manufacturers assured us that they could produce stainless steel - Inconel concentric tubes metallurgically bonded. One supplier agreed to produce a sample lot for evaluation purposes. An order was, therefore, placed for two hundred and fifty feet of tubing. However, we were subsequently informed that the supplier could not produce a metallurgical bond by their manufacturing methods, but merely a mechanical bond. It was decided that mechanically bonded bimetallic tubing would be satisfactory for our initial evaluation tests, and, since a considerable cost differential existed between these two types of tubing, an investigation of mechanically bonded tubing was therefore undertaken. This report summarizes the results of the evaluation of mechanically bonded, seamless Type 316 stainless steelInconel bimetallic tubing.

\section{TESTS AND DISCUSSION OF RESULTS}

The Type 316 stainless steel-Inconel bimetallic tubing was manufactured by a cold reduction process, which normally would not produce a metallurgical bond between the two metals. This tubing had a one-half inch outside diameter. The wall thickness was .094 inch, including. 064 inch of Type 316 stainless steel and .030 inch of Inconel. Microscopic examination did 
not reveal a growth of grains across the interface, which would be characteristic of a metallurgical bond. However, there was also no distinct line of demarcation between the two metals.

Since the bimetallic tubing will be subjected to thermal shock during service, a break in the bond could occur due to differences in thermal expansion and temperature gradients. A length of tubing was thermal shocked by heating to $1200^{\circ} \mathrm{F}$, and then passing cold water through the tubing. This cycle was repeated twenty-five times.

A series of shear tests was conducted on samples of as-received, as well as thermal shocked, tubing. Shear specimens were prepared from one inch sections. The stainless steel, and approximately .003 to .004 inch of Inconel, were removed from each end of the sample for a distance of $15 / 32$ inch, leaving a $1 / 16$ inch stainless steel collar at the center. The outside diameter of each end of the specimen after machining was approximately . 360 inch. The specimen was then inserted in a $3 / 8$ inch hole in a thick steel plate, and a load was applied through a tensile testing machine to the protruding portion of the specimen. This load produced a shearing stress at the bimetallic interface, and load was increased until the bond failed, or the tube collapsed.

Assuming a metallurgical bond, the ultimate shear strength should be approximately $50,000 \mathrm{psi}$, which would be two-thirds of the ultimate tensile strength of the Type 316 stainless steel. There is no basis for calculating the anticipated shear strength of a mechanical bond.

The test results were as follows:

1. As-Received Tubing

Specimen Number 1 - Tube collapsed at 1925 pounds load.

Specimen Number 2 - Bond failed at 1350 pounds, or ultimate shear stress of $19,200 \mathrm{psi}$.

Specimen Number 3 - Bond failed at 1280 pounds, or ultimate shear stress of 17,100 psi.

2. Thermal Shocked Tubing

Specimen Number 4 - Bond failed at 1400 pounds, or ultimate shear stress of 17,500 psi.

Specimen Number 5 - Tube collapsed at 2380 pounds load.

Specimen Number 6 - Bond failed at 250 pounds, or ultimate shear stress of 3,500 psi. 


\section{CONCLUSIONS}

It may be concluded that the ultimate shear stress is much lower than the calculated value of 50,000 psi and, therefore, no metallurgical bond exists. Nonaxial loading conditions may account for the collapse of specimen numbers 1 and 5 .

Strength properties of the tubing for design purposes are calculated from the maximum allowable stress values for Type 316 stainless steel, as listed in Section VIII of the ASME Boiler and Pressure Vessel Code. The function of the Inconel is to protect the stainless steel from the high temperature water, and strength properties are of no concern. An original estimate stated that the minimum wall thickness of the Inconel for a one half inch bimetallic tube must be .030 inch. However, we were subsequently informed that tubing with Inconel of a wall thickness of .010 inch can be produced to commercial tolerances. Using mechanically bonded bimetallic tubing, and assuming a break in the bond occurred at the maximum service temperature due to thermal expansion and temperature differentials, the heat transfer characteristics of the tubing would not be imparied, as the high internal pressure within the tube would still maintain intimate contact of the .010 inch Inconel with the stainless steel tube wall.

As a result of this investigation, it may be concluded that the mechanically bonded bimetallic tubing will be satisfactory for service in the superheater, and the additional cost of metallurgically bonded tubing cannot be economically justified. Additional correspondence with the tube manufacturers indicates that metallurgically bonded bimetallic tubing is now available at only a slight increase in cost over that of mechanically bonded tubing. On this basis, the metallurgically bonded tubing would be preferred. 
- 


\section{SECTION 6}

TRANSITION WELD TEST 
OBJECTIVE

DESCRIPTION OF TEST EQUIPMENT

DESCRIPTION OF TEST

RESULTING STRESSES

69

TRANSIENT STRESS COMPUTATIONS

\section{LIST OF FIGURES}

$\underline{\text { Page }}$

Figure 6-1 Sketch of Test Piece 66

$\begin{array}{lll}\text { Figure 6-2 Test Arrangement } & 67\end{array}$

$\begin{array}{lll}\text { Figure 6-3 Curve of Thermal Cycle } & 71\end{array}$

Figure 6-4 Surface and Bending Stress Diagram 73

\section{LIST OF TABLES}

$\underline{\text { Page }}$

$\begin{array}{lll}\text { Table 6-1 Heating Cycles } & 68\end{array}$

$\begin{array}{lll}\text { Table 6-2 Stresses Resulting from Thermal Cycling } & 72\end{array}$ 


\section{OBJECTIVE}

The objective of this test was first, to determine the feasibility of making a transition weld between Type 316 stainless steel and $2-1 / 4 \%$ chromium $-1 \%$ molybdenum steel in thick sections, such as would be used in joining the lower tubesheet of the superheater to the steam dome; and second, to determine the reliability of the transition weld under conditions of alternating stress caused by temperature or pressure variations.

The test specimen used is shown in cross section in Figure 6-1. It was successfully made up, except for the appearance of shallow surface cracks found adjacent to the weld on the chromium-molybdenum steel side. These cracks resulted from a carbon steel bead used to hold the run-off tabs, and can be eliminated in future work. These cracks were removed by grinding to a depth of approximately $1 / 6$ inch.

\section{DESCRIPTION OF TEST EQUIPMENT}

The test piece was placed in a steel tank. Surrounding the test piece, was a heater assembly made of Nichrome-V ribbon, mounted on an insulation cylinder, supported in turn by a steel cylinder. The heater assembly was suspended from a one con stationary hoist, which allowed automatic lowering and raising of the heater unit. The steel tank was equipped with city water supply lines, controlled by a solenoid valve and a drain line. An axial fan blew continuously across the holding tank, in such a manner that during the heating portion of the cycle the heater cylinder shielded the test piece from the cooling air stream. A thermocouple, imbedded in the midthickness of the test piece about one inch away from the weld, controlled cycling automatically through a temperature recorder-controller. Suitable mechanical-electrical interlocks were provided to prevent spraying of water while the heater was surrounding the test piece, or lowering the heater if there was water in the tank.

A magnetic cycle counter kept a record of the number of cycles applied to the test piece. Figure 6-2 shows the testing arrangement in simplified form.

\section{DESCRIPTION OF TEST}

The test piece was thermally cycled one hundred and sixty-five times. The range in temperature was from 300 to $900^{\circ} \mathrm{F}$, as measured by a control 


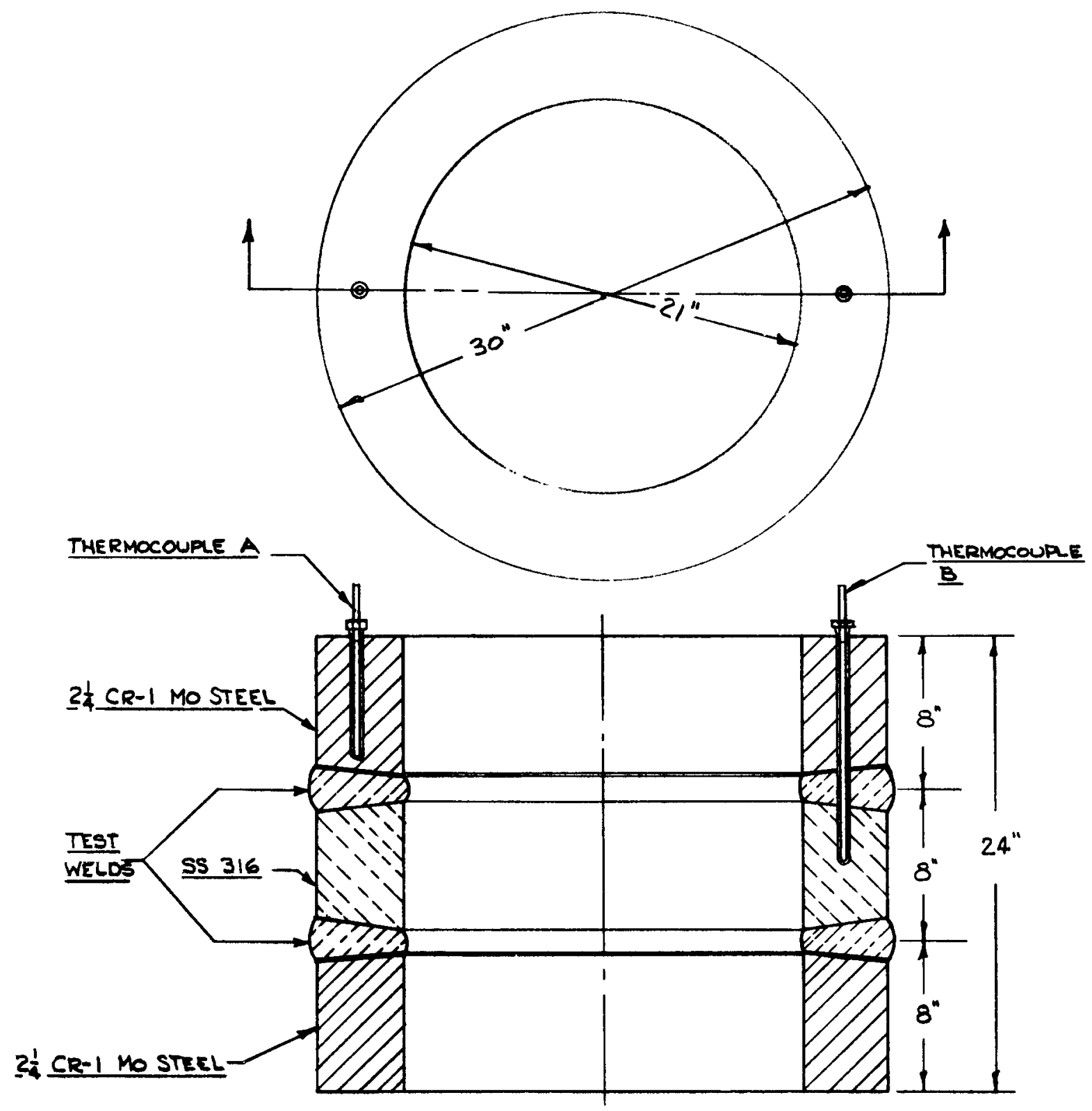

Figure 6-1 Sketch of Test Piece 


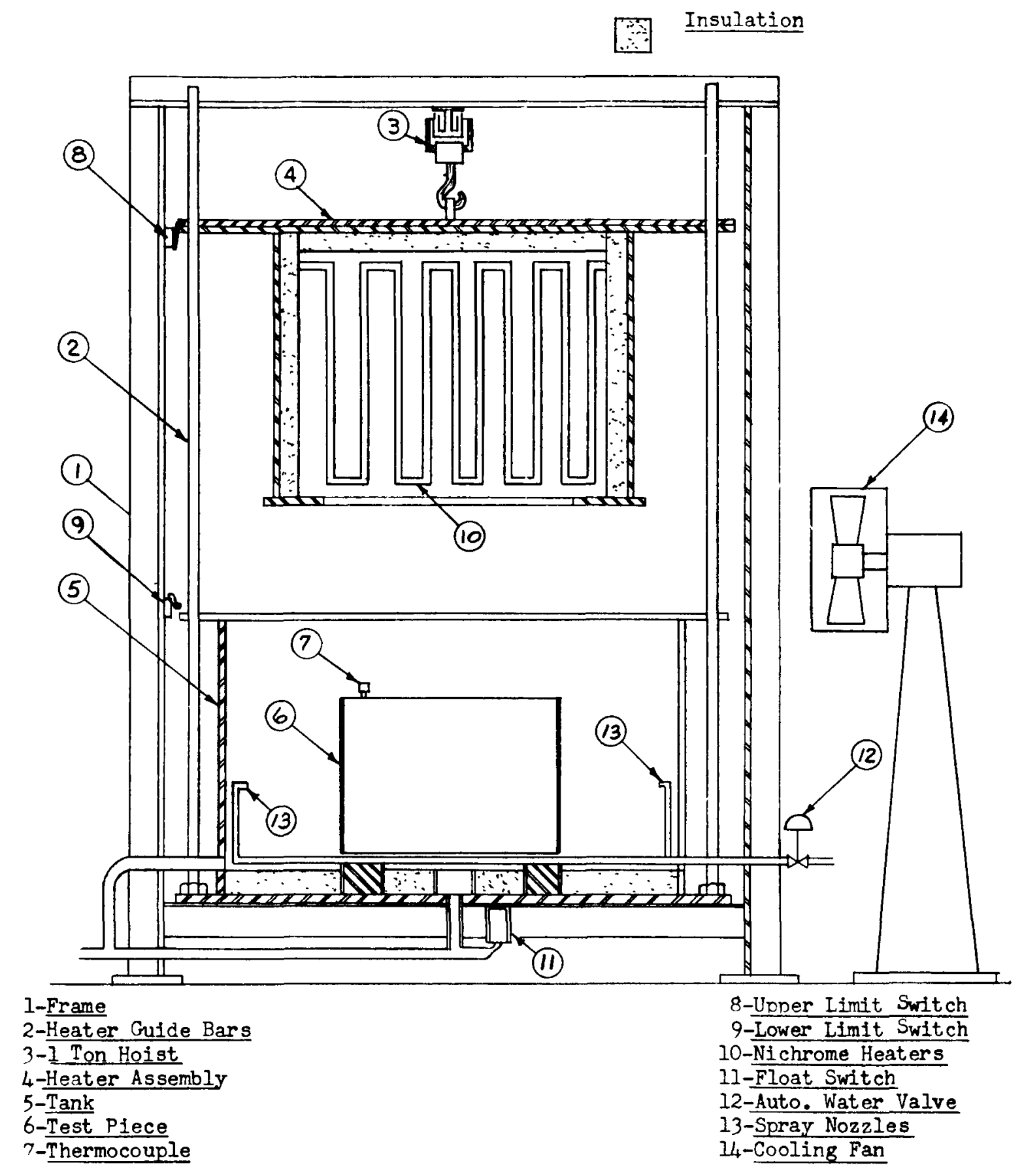

Figure 6-2 Test Arrangement 
thermocouple placed at point $A$, in the midpoint of the 4.5 inch thick $2-1 / 4 \%$ chromium steel. This cycling is considerably more severe than any cycling to which the weld in the finished structure would be subjected. In careful inspections during and following the cycling, no cracks or other damage whatever could be detected, either in the welds or in the adjacent parent metal.

Each cycle consisted of three phases: (1) heating, (2) air cooling, and (3) water cooling. In phase one, the specimen was heated, using Nichrome $\mathrm{V}$ ribbon heating coils placed around the periphery, until the control thermocouple, placed at point $A$ within the upper ring, reached $900^{\circ} \mathrm{F}$. Heat transfer was mainly by radiation, supplemented by natural convection; the air currents being upon the outside, and down through the center. When $900^{\circ} \mathrm{F}$ was reached, the steel cylinder holding the heating coils was raised, and the test cylinder was air cooled to $500^{\circ} \mathrm{F}$. Water spray was then automatically turned on, completing the cooling to $300^{\circ} \mathrm{F}$; whereupon the cycle was repeated.

The heating cycles are tabulated in Table 6-1.

TABLE 6-1

HEATING CYCLES

\begin{tabular}{|c|c|c|c|}
\hline & Degrees F & $\begin{array}{l}\text { Time in } \\
\text { Minutes }\end{array}$ & $\begin{array}{c}\text { Degrees } \\
\text { per Minute }\end{array}$ \\
\hline Cycles 1 to 22 & $\begin{array}{l}294 \text { to } 900 \\
900 \text { to } 478 \\
478 \text { to } 300\end{array}$ & $\begin{array}{r}41 \\
99 \\
9\end{array}$ & $\begin{array}{r}14.8 \\
4.3 \\
19.8\end{array}$ \\
\hline Cycles 23 to 60 & $\begin{array}{l}330 \text { to } 890 \\
890 \text { to } 500 \\
500 \text { to } 320\end{array}$ & $\begin{array}{r}112 \\
50 \\
13\end{array}$ & $\begin{array}{r}5.0 \\
7.8 \\
13.8\end{array}$ \\
\hline Cycles 61 to 165 & $\begin{array}{l}320 \text { to } 890 \\
890 \text { to } 500 \\
500 \text { to } 320\end{array}$ & $\begin{array}{r}97 \\
52 \\
5\end{array}$ & $\begin{array}{r}5.9 \\
7.5 \\
36.0\end{array}$ \\
\hline
\end{tabular}

After the twenty-second cycle, the heating coils burned out and had to be replaced by new coils of somewhat lower wattage. Shields were installed after the sixtieth cycle, to protect the power connections from overheating. Changes in position of the air fan and of the water spray accounted for the changes in the rates of cooling. 
During the one hundred sixty fifth cycle, the control thermocouple leads became shorted, so that the heating coils ran continuously for ten hours before the furnace was shut off. At the end of that time the test cylinder, as gaged by appearance and by use of Tempilstiks, had reached a temperature of approximately $1600^{\circ} \mathrm{F}$.

\section{RESULTING STRESSES}

The rates of heating and cooling varied so much between different groups of cycles that only a general statement as to stress ranges during the testing can be made. Reasonably accurate estimate of stresses can be made for cycles one to twenty-two, and for the high temperature run at the end of the test, but only approximate figures can be given for the intermediate cycles.

During the final cycle, the rate of heating was relatively slow, so that surface stresses, due to temperature differentials between surface and core, were not large. The heat was kept on long enough to develop a reasonably uniform temperature of about $1600^{\circ} \mathrm{F}$ throughout the entire volume of metal. Differential expansion between the Type 316 stainless steel and the $2-1 / 4 \%$ chromium-1\% molybdenum steel rings would cause a mismatch at the welds of $\frac{25.5}{2}(1600-70)(10.6-8.0) 10^{-6}=.0507$ inch.

$$
2
$$

Treating the three rings as beams of finite length, on elastic foundation, and assuming elastic behavior, this mismatch would correspond to a computed bending stress at the welds of $177,700 \mathrm{psi}$, tension on the outer face and compression on the innerface. This stress, of course, occurred only once.

During the successive heating and cooling cycles, the major stress resulted both from the difference in expansion coefficient between the two metals, and from the differences in temperature between the outer surface and the core of the metal. No direct measurements of surface temperature were made, but particularly for the first group of cycles, these temperature differences can be estimated.

During heating, heat transfer to the test piece was primarily by radiation to the outside surface, following the law $\mathrm{Q}=\mathrm{C}\left(\mathrm{T}_{1}{ }^{4}-\mathrm{T}_{2}{ }^{4}\right)$, where $\mathrm{T}_{1}$ is the absolute temperature of the heating coils and $\mathrm{T}_{2}$ is the absolute temperature of the surface of the test piece. $C$ is a constant, dependent upon the reflectivity (or absorptivity) of the metal surface. Particularly during the first group of cycles, $\mathrm{T}_{1} 4$ was so large, as compared to $\mathrm{T}_{2}{ }^{4}$, that changes in $\mathrm{T} 2$ during the heat up did not greatly change the heat received per minute. This was evidenced by the almost straight line temperature rise curves. As soon as stable conditions were established, the BTU 
received per minute on the outer face would equal the BTU carried by conduction to the interior, and, in turn would equal the BTU required to raise the metal temperature at the measured rate per minute. Knowing the metal conductivity, the temperature differential required to conduct heat at this rate could be determined.

Temperature gradients would be different for the Type 316 stainless steel and the $2-1 / 4 \%$ chromium-1\% molybdenum steel sections, due first to the lower thermal conductivity, and second to the higher reflectivity of the stainless steel. Under the heating cycles, the $2-1 / 4 \%$ chromium-1\% molybdenum steel rapidly tarnished, while the stainless steel more nearly retained its initial shiny surface. Figure 6-3 shows temperature readings taken simultaneously by the control ther mocouple, located at midthickness one inch above the upper weld in the $2-1 / 4 \%$ chromium-1\% molybdenum steel, and a second thermocouple, located at midthickness in the stainless steel ring four inches below the upper weld. In this particular cycle, the chromium-molybdenum steel rose from $300^{\circ} \mathrm{F}$ to $895^{\circ} \mathrm{F}$ at 11.7 degrees per minute, while the stainless steel rose from $285^{\circ} \mathrm{F}$ to $620^{\circ} \mathrm{F}$ at 8 degrees per minute, or 68.4 per cent as fast.

The thermal expansion above $70^{\circ} \mathrm{F}$ was as follows:

$$
\begin{aligned}
& 2-1 / 4 \% \text { chromium }-1 \% \text { molybdenum steel } \frac{25.5}{2}(895-70) \times 7.8 \times 10^{-6}=.0820 \text { inch } \\
& \text { Type } 316 \text { stainless steel } \quad \frac{25.5}{2}\left(\begin{array}{c}
620-70) \times 9.8 \times 10^{-6} \\
\text { Mismatch }
\end{array}=\frac{.0697 \text { inch }}{.0123}\right. \text { inch }
\end{aligned}
$$

Due to the lower temperature of the stainless steel, the mismatch is in the opposite direction from what would occur with uniform temperature. The corresponding bending stress at the weld is $.0123 \times \frac{35,000}{.010}=43,000 \mathrm{psi}$, tension on the outerface.

These bending stresses depend only on the total change in temperature, and are independent of the rate of change. To these must be added the surface stresses which result from transient temperature gradients across the thickness of the piece. Rapid changes in temperature accentuate these gradients, and so increase these surface stresses. There has been no direct measurement of surface temperatures, but they can be estimated by indirect methods, remembering that once a steady rate of temperature increase has been reached, the heat received by radiation per minute must equal the heat transferred by conduction through the metal, and, in turn, must equal the heat required to warm up the metal at the measured rate. Computations given on pages 74 to 75 indicate that the resulting surface stress in and adjacent to the weld will approximate 3,900 psi per degree per minute rate of change in temperature. Applying this factor to the measured rates of change in the different cycles results in the stresses shown in Table 6-2. 


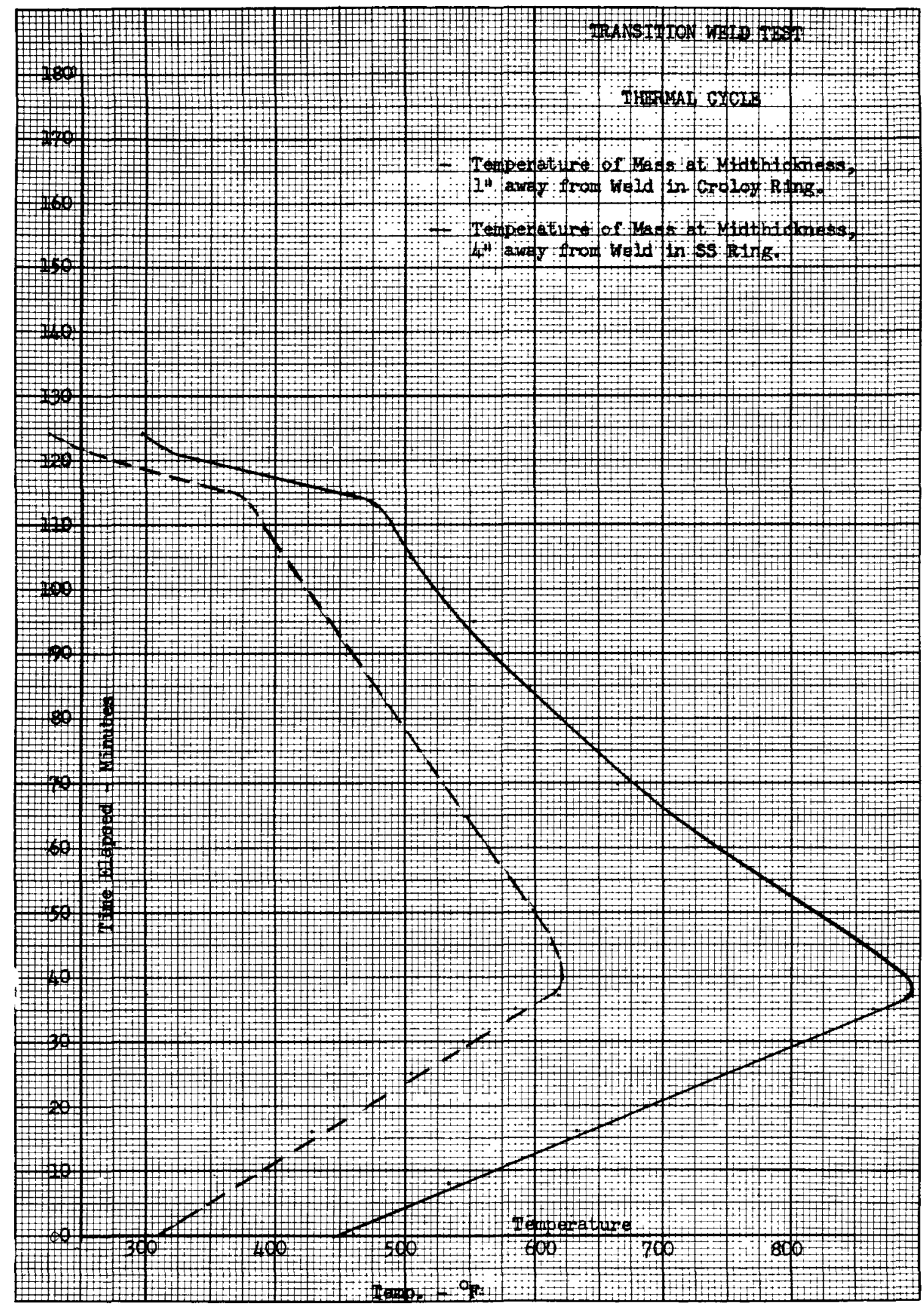

Figure 6-3 Curve of Thermal Cycle 
TABLE 6-2

APPROXIMATE STRESSES RESULTING FROM THERMAL CYCLING

Rate

Deg./Min.

Stress, psi

Cycle 1 to 22

$\begin{array}{lcc}\text { Heating } & 14.8 & 58,000 \text { compression } \\ \text { Air Cooling } & 4.3 & 17,000 \text { tension } \\ \text { Water Cooling } & 19.8 & 77,000 \text { tension } \\ & \text { Range } & 135,000 \mathrm{psi}\end{array}$

Cycles 23 to 60

Heating

Air Cooling

Water Cooling

5.0

7.8

13.8

Range

19, 500 compression

31,000 tension

54,000 tension

73,500 psi

Cycles 61 to 165

Heating

5.9

7.5

Air Cooling

36.0

23, 000 compression

Water Cooling

Range

29,000 tension

140,000 tension

$163,000 \mathrm{psi}$

These surface stresses must be combined with the bending stresses. Figure 6-4 gives a better understanding of the way in which this combination occurs. Maximum compressive stress occurs soon after heating begins, before the mean temperature has risen too high. Maximum tension occurs soon after the air cooling begins, and again soon after the spray has started, due to the bending and the surface cooling stress. This combination will result in increasing the stress range during the test to somewhat higher figures than those just given.

For comparison in the steam generator as actually designed, the normal stress range at the weld, pressure and thermal stress combined, should not exceed 50,000 psi, with a possible emergency value of 70,000 psi. 


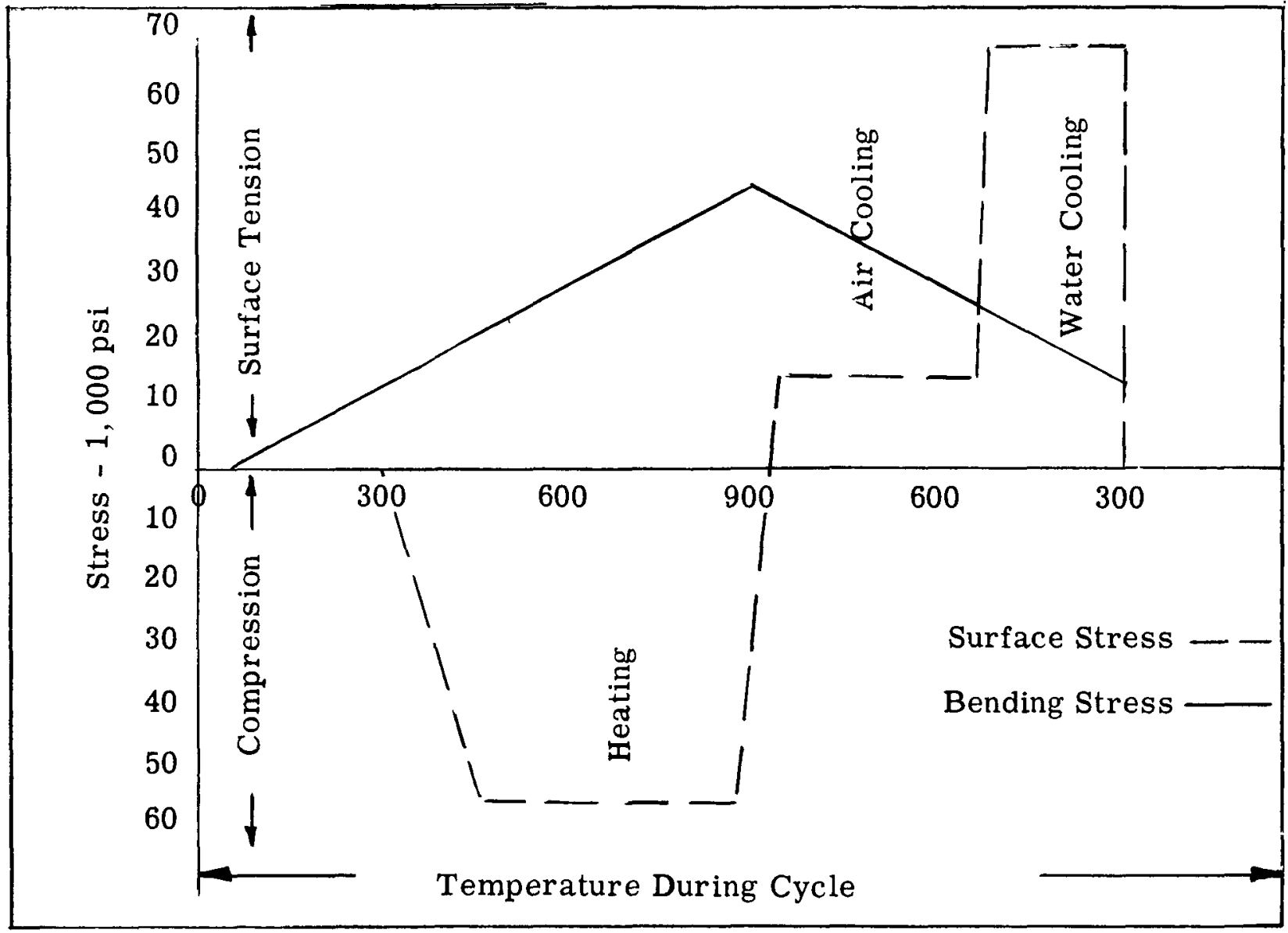

FIGURE 6-4

SURFACE AND BENDING STRESS DIAGRAM

TRANSIENT STRESS COMPUTATIONS

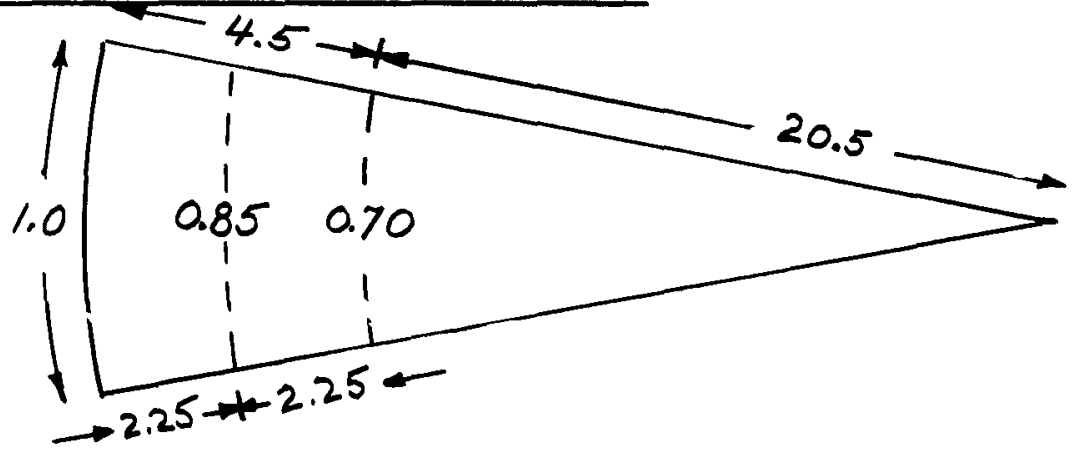


Per square inch of outside surface, the weight of $2-1 / 4 \%$ chromium-1\% molybdenum steel:

Outside of centerline: $0.925 \times 2.25 \times 0.283=0.589$ pound.

Centerline to inside: $0.775 \times 2.25 \times 0.283=0.494$ pound.

$$
\text { Total } 1.083 \text { pound }
$$

Assume a unit rise in metal temperature of one degree per minute.

Then heat entering per minute $=0.16 \times 1.083=0.173 \mathrm{Btu} / \mathrm{sq} \mathrm{in.} / \mathrm{min}$ heat passing centerline $=0.16 \times 0.494=0.0790 \mathrm{Btu} / \mathrm{sq} \mathrm{in.} / \mathrm{min}$

For a thermal conductivity of $16.4 \mathrm{Btu} / \mathrm{hr}-\mathrm{ft}-{ }^{\circ} \mathrm{F}$, temperature gradient at outside surface $=\frac{0.173 \times 144 \times 60}{16.4 \times 12}=7.6 \% / \mathrm{inch}$

at centerline $=\frac{0.079 \times 144 \times 60}{16.4 \times 12}=3.47 \%$ inch

Temperature differential, surface to centerline $=2.25 \times \frac{7.6+3.47}{2}=12.45^{\circ} \mathrm{F}$

$$
\text { Centerline to inner surface }=2.25 \times \frac{3.47+0}{2}=3.9^{\circ} \mathrm{F}
$$

Temperature distribution across thickness will be nearly parabolic, with difference between outside face and mean temperature equal to

$$
\begin{aligned}
& 2 / 3(12.45+3.9)=10.9^{\circ} \mathrm{F} \\
& \text { Stress }=\frac{E \propto \Delta T}{0.7}=\frac{25 \times 10^{6} \times 9 \times 10^{-6} \times 10.9}{0.7}=3,500 \mathrm{psi} /{ }^{\circ} \mathrm{F} / \mathrm{min}
\end{aligned}
$$

For stainless steel, with density 0.290 , thermal conductivity 11.0 , and specific heat $=0.16$, difference between outerface temperature and mean temperature, per ${ }^{\circ} \mathrm{F}$ per minute rise in mean temperature,

$$
\begin{aligned}
& \quad=10.9 \times \frac{0.290}{0.283} \times \frac{16.4}{11.0}=16.65^{\circ} \mathrm{F} \\
& \text { Stress }=\frac{E \alpha \Delta \mathrm{T}}{0.7}=\frac{24.0 \times 10^{6} \times 11 \times 10^{-6} \times 16.65}{0.7}=6,240 \mathrm{psi} /{ }^{\circ} \mathrm{F} / \mathrm{min}
\end{aligned}
$$

Correcting to obtain the expected surface, stress in the stainless steel per degree Fahrenheit rise in $2-1 / 4 \%$ chromium-1\% molybdenum temperature

$$
6240 \times 0.684=4260 \mathrm{psi} /{ }^{\circ} \mathrm{F} / \mathrm{min}
$$


The surface stress at and near the weld will lie between 3,500 and 4,260 psi, or say 3,900 psi per degree Fahrenheit per minute temperature change.

These equations should apply quite accurately to the heating stages in cycles one to twenty-two. The average heating rate for the control thermocouple was $14.8^{\circ} \mathrm{F} / \mathrm{min}$. This would indicate a heat input of $0.173 \times 14.8$ $=2.56 \mathrm{Btu}$ per minute per square inch. As verification, the computed heat transfer by radiation, assuming heating coils at $2000^{\circ} \mathrm{F}$, ring surface at $800^{\circ} \mathrm{F}$, and a reflectivity factor of 0.40 , would be

$$
\begin{aligned}
Q & =1730\left[\frac{(2460)^{4}}{(1000)}-\frac{(1260)^{4}}{(1000)}\right] \times 0.40=23,600 \mathrm{Btu} / \mathrm{sq} \mathrm{ft} / \mathrm{hour} \\
& =\frac{23600}{60 \times 144}=2.73 \mathrm{Btu} / \mathrm{sq} \mathrm{in.} / \mathrm{min}
\end{aligned}
$$

The surface stress at the weld would be $14.8 \times 3900-57,200 \mathrm{psi}$. compression present during most of the heating cycle. The stress on the inside of the ring would be tension, and half as great. 
•

- 
SECTION 7

BAYONET TUBE TEST 


\section{BAYONET TUBE TEST}

TABLE OF CONTENTS

\begin{tabular}{|c|c|c|}
\hline & & Page \\
\hline 1. & INTRODUCTION & 82 \\
\hline 2. & 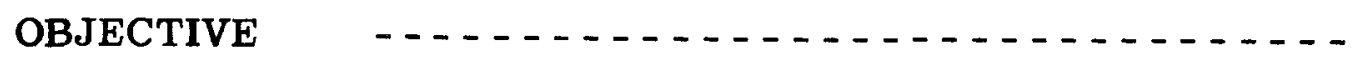 & 83 \\
\hline 3. & DESIGN CONSIDERATIONS $-\ldots \ldots$ & 84 \\
\hline 4. & TEST EQUIPMENT AND PROCEDURE & 85 \\
\hline 5. & DATA $\quad \ldots \ldots \ldots \ldots \ldots \ldots$ & 91 \\
\hline 6. & ANALYSIS $\ldots \ldots$ & 92 \\
\hline 7. & RESULTS $-\cdots,-\ldots, \ldots \ldots \ldots$ & 93 \\
\hline 8. & CONCLUSIONS $\ldots \ldots \ldots$ & 99 \\
\hline 9. & 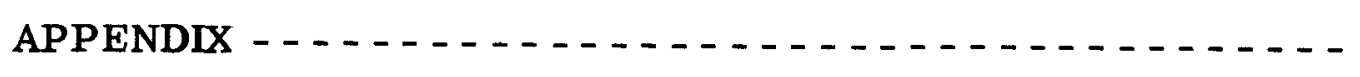 & 100 \\
\hline & BIBLIOGRAPHY - & 103 \\
\hline
\end{tabular}




\section{LIST OF FIGURES}

$\underline{\text { Page }}$

Figure 7-1 Bayonet Tube Test Set-Up

Figure 7-2 Schematic of Test Unit $\quad 86$

$\begin{array}{lll}\text { Figure 7-3 Schematic of Test Loop } & 87\end{array}$

Figure 7-4 Location of Tube and Heater Wall Thermocouples 90

Figure 7-5 Bayonet Tube Heat Transfer Distribution 95

Figure 7-6 Bayonet Tube Outside Wall Temperatures 96

$\begin{array}{lll}\text { Figure 7-7 Boiler Water Level Effects } & 98\end{array}$

LIST OF TABLES

Table 7-1 Test Results at Full Load 


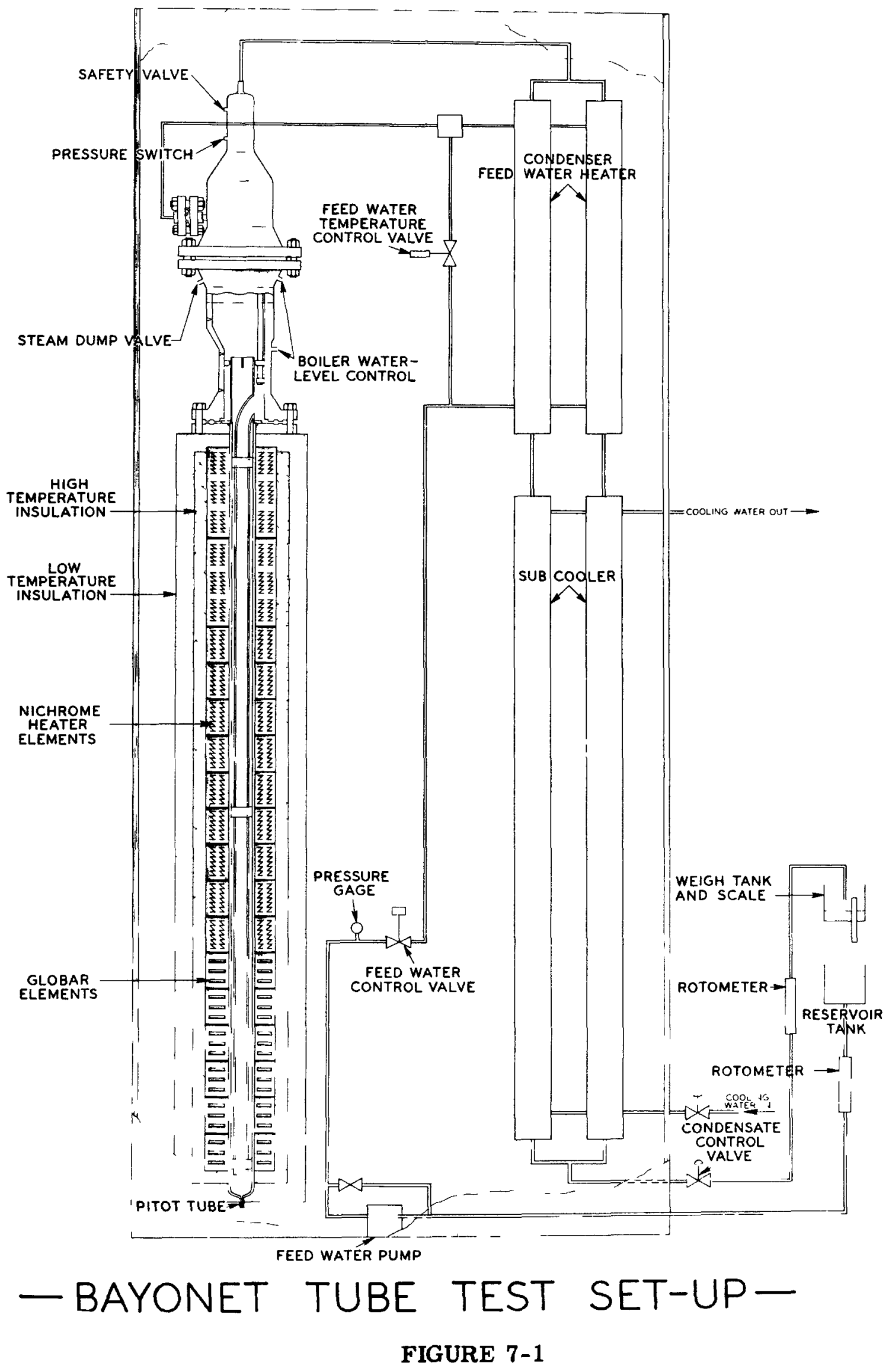




\begin{tabular}{|c|c|c|}
\hline DP & - Differential pressure (pitot tube) & $" \mathrm{H}_{2} \mathrm{O}$ at $62.4 \# / \mathrm{ft}^{3}$ \\
\hline$h_{f}$ & - Enthalpy of saturated water & BTU/\# \\
\hline$h_{f g}$ & - Enthalpy of evaporation & BTU/\# \\
\hline hFWl & - Enthalpy of feedwater at condenser inlet & BTU/\# \\
\hline $\mathrm{h}_{\text {FW2 }}$ & - Enthalpy of feedwater at boiler inlet & BTU/\# \\
\hline hsD1 & - Enthalpy of steam at boiler discharge & BTU/\# \\
\hline hsD2 & - Enthalpy of condensate at condenser discharge & BTU/\# \\
\hline P-BD-1 & - Pressure at boiler drum & PSI \\
\hline P-FW-2 & - Pressure, feedwater at boiler inlet & PSI \\
\hline P-SD-2 & - Pressure, condensate at condenser discharge & PSI \\
\hline QBL & $\begin{array}{l}\text { Heat transfer loss; boiler drum and equalizing } \\
\text { columns of boiler water level measuring in- } \\
\text { struments }\end{array}$ & BTU/HR \\
\hline QCL & - Heat transfer loss; condenser & BTU/HR \\
\hline QG & - Gross power to primary heaters & KW \\
\hline QN & - Net heat transfer to water in bayonet tube & BTU/HR \\
\hline T-FW-1 & - Temperature (feedwater condenser unit) & $\mathbf{F}$ \\
\hline T-FW-2 & - Temperature (feedwater at boiler inlet) & $\mathbf{F}$ \\
\hline T-SD-2 & - Temperature (condensate at condenser discharge) & $\mathbf{F}$ \\
\hline $\mathbf{V}$ & - Water velocity in inner tube of bayonet tube & $\mathrm{ft} / \mathrm{sec}$ \\
\hline$v_{f}$ & - Specific volume, saturated liquid & $\mathrm{ft}^{3} / \#$ \\
\hline $\mathbf{W}_{\mathbf{F W}}$ & - Flow rate, feedwater at boiler inlet & $\mathrm{lb} / \mathrm{hr}$ \\
\hline $\mathrm{W}_{\text {SD }}$ & - Flow rate, steam at boiler outlet & $\mathrm{lb} / \mathrm{hr}$ \\
\hline $\mathrm{XSD1}_{\mathrm{SD}}$ & - Steam quality, boiler outlet & $\frac{\mathrm{lb} \text { of steam }}{\mathrm{lb} \text { of mixture }}$ \\
\hline
\end{tabular}




\section{INTRODUCTION}

The preliminary design of the $70 \mathrm{MW}$ steam generator ${ }^{(1) *}$ combines a natural circulation boiler, spherical separating drum, and superheater into one vertical unit utilizing liquid sodium from the intermediate heat exchanger as the heat source. In the design of the natural circulation boiler section, the tube bundle is composed of 486 bayonet tubes ( 2 inch O. D. , No. 5 B.W.G., approximately 16 feet long) which are suspended from the lower portion of the spherical steam druin. Each of these 2 inch tubes contains a 1 inch tube (No. 20 B.W.G.) attached at the top end to permit the saturated water in the lower portion of the steam drum to flow downward through the inner tube. Clearance between the bottoms of these tubes permits the water to turn and flow upward in the annulus between the two tubes. Risers are connected to the upper end of the bayonet tubes to extend the outer tubes to a specified level within the spherical steam drum.

The heat transfer from the outer tube wall to the water in the annulus progressively forms steam which flows upward through the risers into the separating drum. The density difference between the steam-water mixture in the annulus and the saturated liquid inside the 1 inch tube causes natural circulation to occur. The steam released from the liquid surface in the drum flows upward through a horizontal perforated plate (called a bubble deck).

The feedwater enters the spherical separating drum above the bubble deck and is distributed onto the outer circumference of the deck by a cylindrical shroud. The feedwater flows towards the center of the deck being heated to saturated liquid by the steam which bubbles from the perforations in the deck. The projection of the central downcomer pipe above the deck surface forms a circular weir that controls the depth of liquid over the deck. The saturated liquid flows over the weir, into the downcomer, and to the bottom of the drum where it enters the inner bayonet tubes.

Steam separation is accomplished by first having a low vapor release velocity at the liquid surface and second by bubbling the steam through the feedwater. Part of the steam is condensed to heat the feedwater and the remainder is released above the feedwater to enter the superheater.

In order to have some assurance that the natural circulation bayonet tube boiler operates as described and is capable of generating the design steam flow, it was proposed that a single bayonet tube of full size be tested at full load conditions. The following is a report of this test.

* Numbers in parentheses refer to the Bibliography at the end of this report. 


\section{OBJECTIVE}

To test a single bayonet tube model of the boiler and separating drum sections of the steam generator design in order to evaluate its predicted performance and operation under simulated full load conditions. 


\section{DESIGN CONSIDERATIONS}

The test unit was designed with all vertical dimensions the same as in the full size steam generator in order to duplicate the rate of natural circulation. The horizontal dimensions of the steam separating drum were reduced to give proportional flow areas with the same steam-water velocities as in the actual design. The internal design of the separating drum was made similar to maintain design conditons at the inlet and outlet of the bayonet tube and to duplicate the steam separation process. The number of bayonet tubes was reduced from 486 to 1 with the tube configuration and size identical to the actual design.

A series of electric radiant heaters positioned along the heated length of the bayonet tube was used to simulate the sodium heat source. The heaters were arranged to correspond to the crossflow layers of sodium between the overlapped disc and doughnut baffles. The individual heaters were designed with the required power and control to provide the heat transfer and temperature distribution of the outside tube surface as predicted for the actual design. 


\section{TEST EQUIPMENT AND PROCEDURE}

In general, the test equipment can be divided into four sections which include the test unit, test loop, controls and instrumentation. A brief description of the operation of the equipment in each section is presented below. A complete list of the equipment and manufacturers is presented in the Appendix 9. 2.

After the test set-up was completed, familiarization with the operation of the test equipment was accomplished through a period of initial operation. Full power input and output was reached in two steps. First, at low power input, the design pressure was attained. Second, the power input to the radiant heaters was gradually increased until a net power input to the bayonet tube reached approximately the full load condition or $82 \mathrm{KW}$ at $2200 \mathrm{psig}$. This load condition was held for approximately 74 hours.

\subsection{Test Unit}

The schematic of the bayonet tube test unit is shown in Figure 7-2. As previously mentioned, the bayonet tube and height of the various internal parts are the same as in the actual unit while the flow areas are respectively proportional to the actual flow area.

In brief, the operation is as follows: feedwater enters the upper section of the test unit through a $3 / 8$ inch line into a region simulating the cylindrical shrouded inlet. The feedwater flows under the shroud through a small rectangular opening and across the bubble deck where it is preheated to $650^{\circ} \mathrm{F}$ saturated liquid by the steam bubbling through the deck. This preheated water then flows over the simulated weir and down the drum downcomer to the inlet of the 1 inch inner bayonet tube. The water flows down the 1 inch tube at a velocity of about 6 feet per second at full load and turns from the lower end to flow up the annulus between the inner and outer tubes. Upon receiving the required heat, which is transferred through the outer tube, steam is progressively generated along the annulus. The steam-water mixture flows into the separating drum section and the steam, released from the liquid surface, bubbles through the feedwater flowing over the deck. Part of the steam is condensed to heat the feedwater and the remainder is released above the feedwater to enter the steam discharge line.

\section{$4.2 \quad$ Test Loop}

A description of the test loop and components will illustrate the degree to which the requirements for operational flexibility have been satisfied. The test loop components are shown in Figure 7-1 (test set-up) and Figure 7-3 (test loop schematic). 


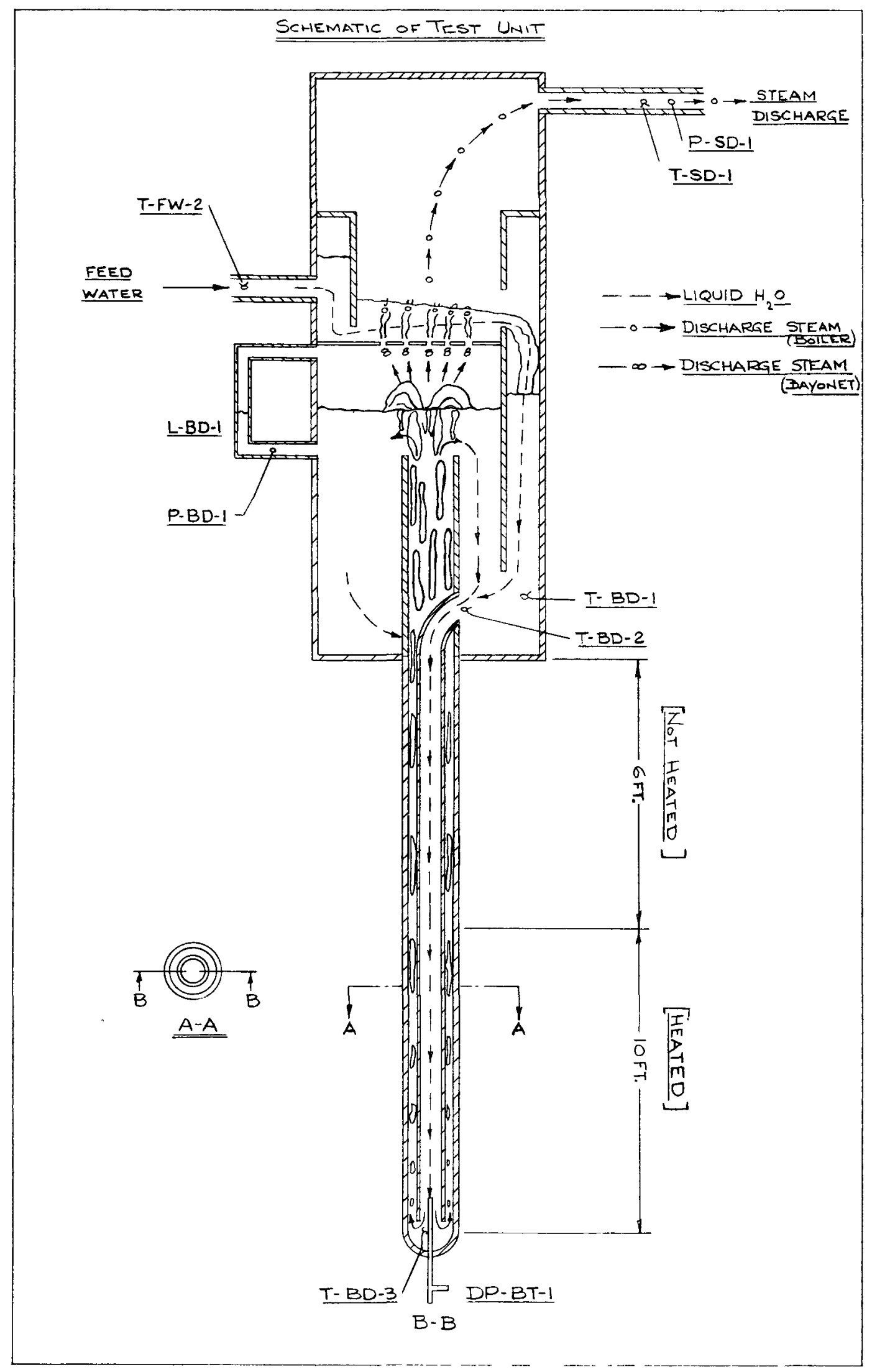

FIGURE 7-2 


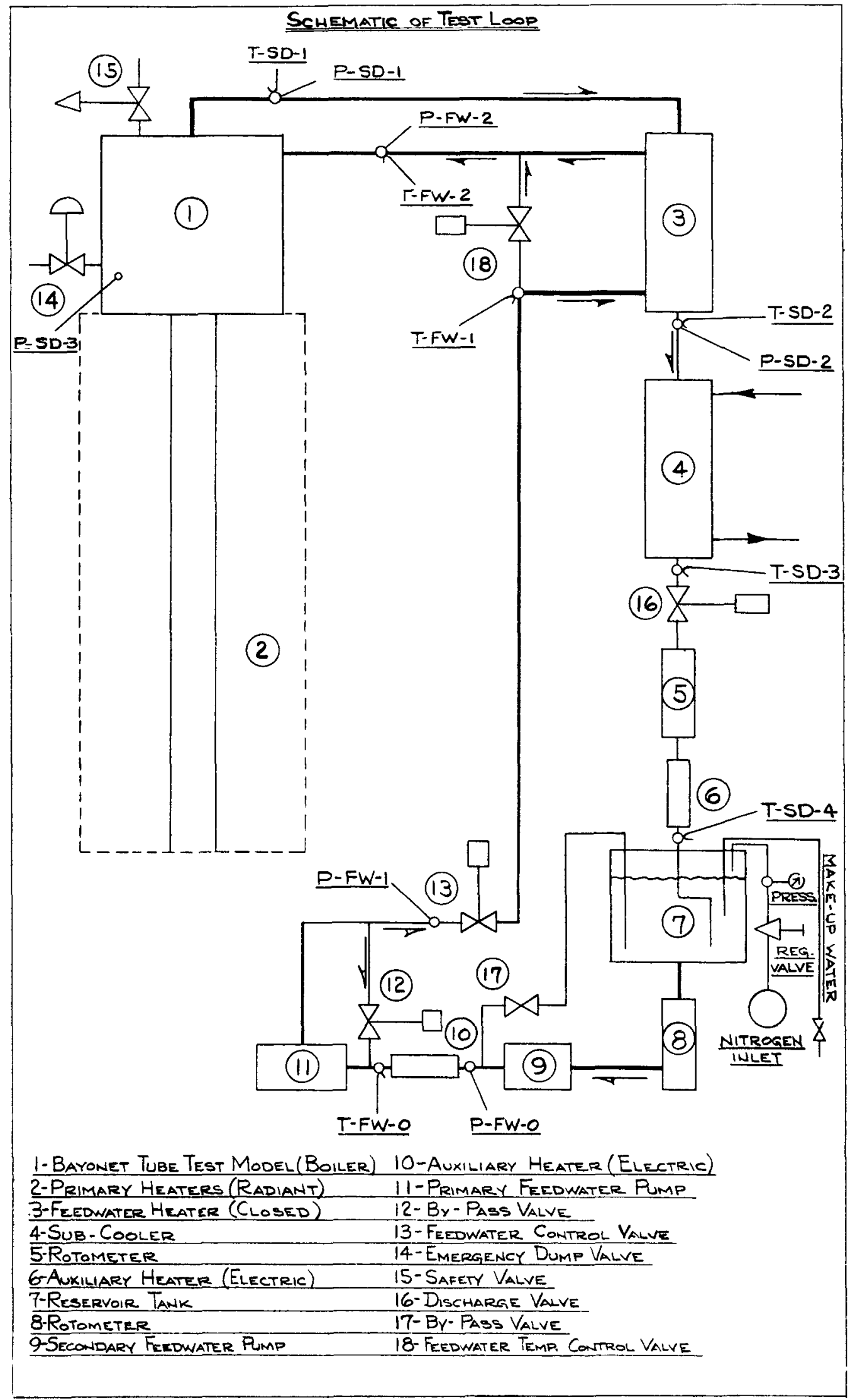

FIGURE 7-3 
In brief, the feedwater flows from the 30 gallon reservoir tank through a rotometer and the secondary feedwater pump to an axuiliary feedwater heater. The feedwater exits this heater at approximately 40 psig., as controlled by a by-pass valve, and enters the primary feedwater pump. At the primary pump inlet a desurger is installed to eliminate pressure and flow pulsations due to the piston type of pump action and the by-pass flow entering the pump inlet.

The feedwater flows from the primary pump discharge through a second desurger and the feedwater control valve to the condenser-feedwater heater. The pressure upstream of the feedwater control valve is governed by the pump relief valve. The pressure of the pump discharge can be controlled from 300 to $3000 \mathrm{psi}$. The action of the feedwater control valve is controlled by the water level controller on the steam separating drum of the test unit.

Part of the feedwater can by-pass the feedwater heater through the feedwater temperature control valve which is manually controlled. During the test, this valve was kept closed because the capacity of the feedwater heater did not require by-passing to reduce the feedwater temperature. The feedwater entered the test unit at a temperature approaching $600^{\circ} \mathrm{F}$.

The generated steam, discharged from the test unit, flows to the condenser-feedwater heater where it is condensed and partially subcooled to supply the energy for heating the feedwater. The condensate from the condenser is further subcooled to $150-180^{\circ} \mathrm{F}$ in the water cooled subcooler . The condenser-feedwater heater is a counter-flow heat exchanger while the subcooler is a parallel-flow heat exchanger. Both units are mounted in the vertical position to facilitate draining of the condensate.

The condensate flows from the subcooler through the condensate discharge valve and the condensate discharge rotometer to the 30 gallon reservoir tank, where this description started. The condensate control valve is air operated with remote or manual control. The condensate rotometer reading is compared to the feedwater rotometer reading for control purposes when operating conditions are set and steady state operation is checked.

To simulate the sodium heat transfer characteristics of the actual design, a series of radiant electric heaters are positioned along the heated length of the bayonet tube. The overall length of the heater assembly is sixteen feet, of which the lower ten feet is used for heating. The bottom six of these ten feet have silicone carbide rods for heating elements, while the other four feet have nichrome ribbon. The top six-foot section of the heater can be used to isothermally control the heat in the tube. The surface of the tube is approximately $3-3 / 4$ inches from the heating element. Each one foot section, except for the top six feet, are separated from the adjacent section by a baffle. Between the baffle and the tubes, there is a $1 / 4$ inch air gap. Separate welding generators supply power to each one foot section of the heater elements which can be independently controlled. 


\section{3 Controls}

The control system is basically a single element pressure compensated water level control. This is a product of the Bailey Meter Company and controls the level by remotely opening or closing the feedwater control valve. Because the primary pump is a piston pump, there is an automatically controlled pump by-pass valve to keep the feedwater pressure constant.

The condensate discharge valve is manually controlled by a remote airoperated control. This valve keeps the steam discharge pressure at the required 2200 psi. Depending on the condensate discharge temperature, the cooling water flow is increased or decreased by a manual globe valve.

\subsection{Instrumentation}

The experimental measurements include electric power, flow rate, pressure, temperature, velocity head and water level taken at various locations as listed in Section 5 of this report. Thermocouples made of icejunctioned chromel-alumel and platinum-platinum rodium were used to measure the various temperatures for monitoring the heat input and for performing heat balance calculations. To measure the bayonet tube surface temperatures and lower heater wall temperatures, platinum-platinum rhodium thermocouples were used. The other wall temperature measurements were made with chromel-alumel thermocouples. Typical locations of tube and heater wall thermocouples are shown in Figure 7-4.

Other temperatures throughout the test loop were measured with chromel-alumel thermocouples. The various locations are shuwn in Figures 7-2 and 7-3. Within the test unit, T-BD-1 is a measurement of the temperature of the feedwater in the lower part of the separating drum downcomer; T-BD-2 is a measurement of the temperature of the inlet water to the inner bayonet tube; while, T-BD-3 is the temperature at the bottom of the inner bayonet tube. These temperatures are at saturation for a pressure of 2200 psig.

Feedwater pressure readings were taken at two points. P-FW-1 was measured between the feedwater control valve and primary feedwater pump. P-FW-2 was measured at the inlet of the test unit. Pressures at the boiler inlet and at steam discharge were continuously recorded by the Bailey Meter recorder. A pressure measurement was also made between the condenser and the subcooler. Along this temperature measurement, it could be determined whether or not the steam was fully condensed upon entering the subcooler.

Flow measurements were made of the feedwater, of the condensate and of the cooling water for the subcooler. In order to determine the rate of flow of the water in the inner bayonet tube, a pitot tube was used to measure the velocity head (DP-BT-1). This was also recorded on the Bailey Meter recorder. 


\section{Location of Tube and HEATER WALL THERMOCOUPLES}

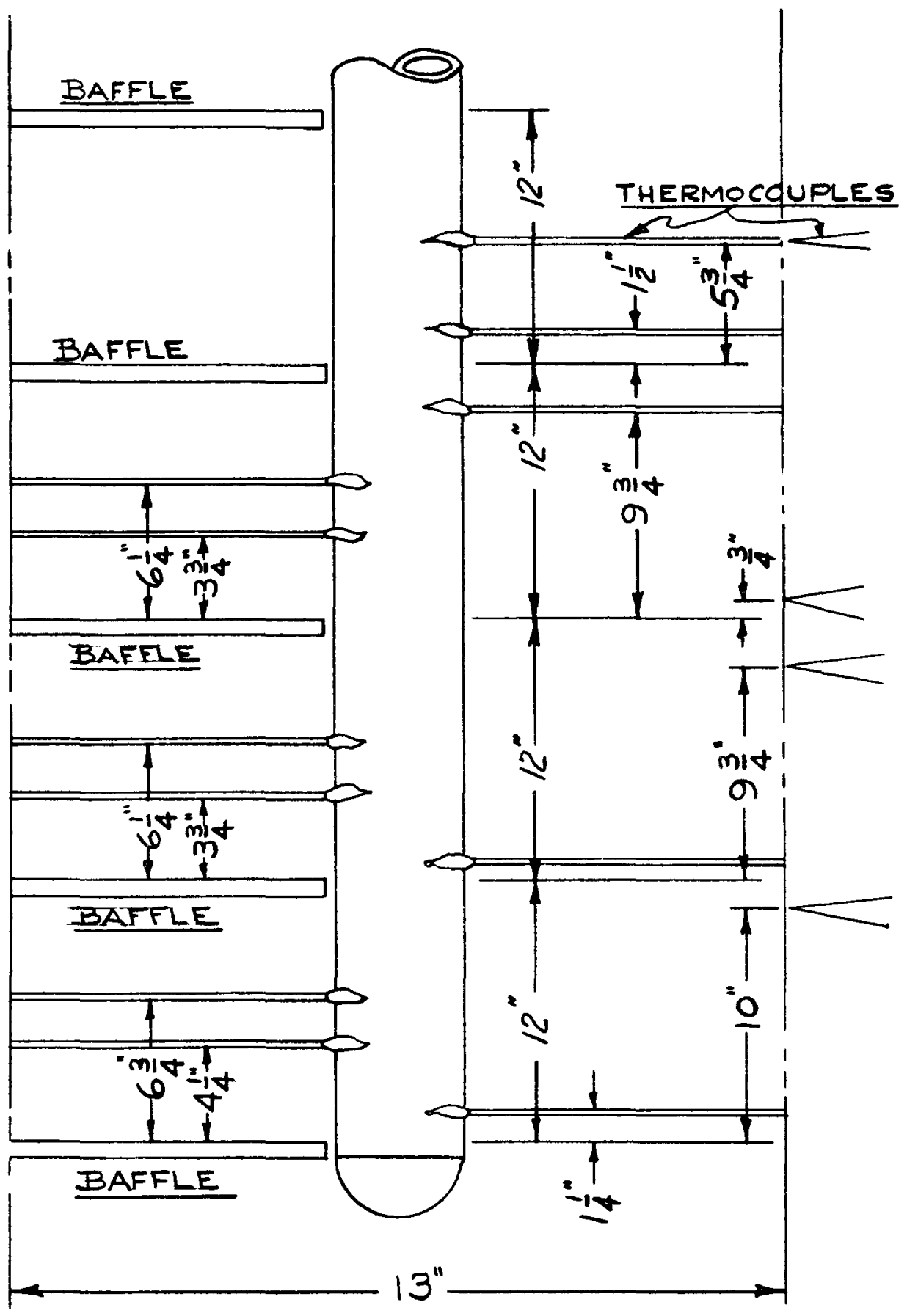

FIGURE 7-4 


\section{DATA}

The following experimental measurements were recorded during each test run:

Electric Power: Volts and Amperes converted to KW Auxiliary Feedwater Heaters

Bayonet Tube Radiant Heaters

Flow Rate: GPM

Condensate - Boiler Output

Cooling Water - Subcooler

Feedwater - Boiler Input

Pressure: PSIG

Condensate at Condenser Discharge

Cooling Water to Subcooler

Feedwater - Pump Discharge

Feedwater - Boiler Inlet

Steam - Boiler Outlet

Steam Drum

Temperature: ${ }^{\circ} \mathrm{F}$

Bayonet Tube - Radiant Heater Wall

Baybnet Tube - Outside Wall

Condensate - Condenser Outlet

Condensate - Subcooler Outlet

Cooling Water - Subcooler Inlet and Outlet

Feedwater - Condenser Inlet and Outlet

Saturated Water - Bottom of Drum Downcomer

Saturated Water - Bottom of Inner Bayonet Tube

Steam - Boiler Outlet

Velocity Head: Inches of Water

Pitot Tube - Inner Bayonet Tube

Water Level: Inches of Water

Boiler Drum

Reservoir Tank 


\section{ANALYSIS}

The analysis includes the method of correlating the test data to obtain: Steam Quality (Boiler Discharge), Net Heat Transfer to the bayonet tube, and Recirculation Velocity.

\subsection{Steam Quality (Boiler Discharge)}

The steam quality at the boiler discharge is obtained by an energy balance for the condenser (Figure 7-3). The feedwater enthalpy change is obtained from the steam tables at the measured states, T-FW-1 and P-FW-2, and T-FW-2, P-FW-2 (neglecting the pressure drop in the condenser). The condensate enthalpy at the condenser discharge is obtained from the steam tables at the measured state, T-SD-2 and P-SD-2.

The enthalpy of the steam at the boiler discharge is obtained from the rearranged energy balance equation,

$$
h_{S D 1}=\frac{W_{F W}}{W_{S D}}\left(h_{F W}-h_{F W 1}\right)+\frac{Q_{C L}}{W_{S D}}+h_{S D 2}
$$

The steam quality is obtained using the enthalpy of saturated liquid and enthalpy of evaporation at the boiler discharge pressure and the steam enthalpy from Equation (6.1.1).

$$
\mathrm{X}_{\mathrm{SD1}}=\left[\frac{\mathrm{h}_{\mathrm{SD} 1}-\mathrm{h}_{\mathrm{f}}}{\mathrm{h}_{\mathrm{fg}}}\right] \quad \text { P-BD-1 }
$$

\subsection{Net Heat Transfer to the Bayonet Tube}

The Net Heat Transfer to the Bayonet Tube is obtained by an energy balance for the Boiler (Figure $7 \bullet 2$ ).

$$
Q_{N}=W_{S D}\left(h_{S D 1}-h_{F W 2}\right)+Q_{B L}
$$

\section{3 Recirculation Velocity}

The recirculation velocity, measured by the pitot tube inside the inner tube of the Bayonet Tube (Figure 7-2) is obtained by correcting the indicated differential pressure of the pitot tube for the density of the water in the inner tube. The density of this water is obtained from the steam tables at the saturated liquid state for P-BD-1 (boiler pressure).

$$
v^{2}=2 g \frac{D P}{12}(62.4) v_{f}
$$




\section{RESULTS}

7. 1

The test results at full load, steady state operation are summarized in Table 7-1. The corrected heat transfer to the bayonet tube was equal to $99.5 \%$ of design full load.

The net heat transfer distribution for the full load tests is shown in Figure 7-5. The test points were obtained by subtracting the heat loss obtained by a heater calibration test from the gross power to the primary heaters. The heat loss calibration was conducted at a heater wall temperature profile predicted from the expected tube wall temperatures and black body radiation with the bayonet tube removed from the heater enclosure. The actual heater wall temperatures measured during the full load test were slightly different than the predicted values. The heater loss was corrected by:

\begin{tabular}{|c|c|c|c|c|}
\hline & & Calibration & & $\begin{array}{c}\text { Full Load Test } \\
\end{array}$ \\
\hline eat Loss & $=$ & Heat Loss & $\mathbf{x}$ & $\begin{array}{l}\text { Calibration Test } \\
\text { Heater Wall Temp. - Ambient Temp. }\end{array}$ \\
\hline
\end{tabular}

This correction was performed individually for each 1 foot section of the heated section of the heater. No power was supplied to the top 6 feet of the heater because the tube wall temperatures in this section were approximately equal to the saturation temperature of the water in the bayonet tube, indicating no heat loss from the tube at this section.

The net heat transfer to the bayonet tube obtained by the summation of the heat transfer shown in Figure $7-5$ is $86 \mathrm{KW}(293,000 \mathrm{BTU} / \mathrm{HR})$. Comparing this value with the corrected net heat transfer from Table 7-1, there is a discrepancy of $4 \mathrm{KW}(14,000 \mathrm{BTU} / \mathrm{HR})$ or approximately $4 \%$ of the gross power to the primary heaters. Compared with the uncorrected net heat transfer of Table 7-1, there is a discrepancy of $8 \mathrm{KW}(28,000 \mathrm{BTU} / \mathrm{HR})$ or approximately $8 \%$ of the gross power to the primary heaters.

The measured bayonet tube outside wall temperatures are shown in Figure 7-6. Observation of the thermocouples at the completion of the tests indicated that approximately half of them were probably indicating higher temperatures than the actual wall temperatures. The thermocouples which had been cemented to the tube wall to minimize the effect of the hot heater wall were no longer attached. For this reason, the temperature points which are close to the design values are considered to be more reliable. 
TABLE $7-1$

\begin{tabular}{|c|c|c|c|c|c|c|c|c|}
\hline \multirow{2}{*}{ 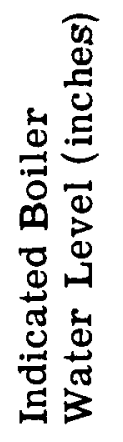 } & \multirow{2}{*}{ 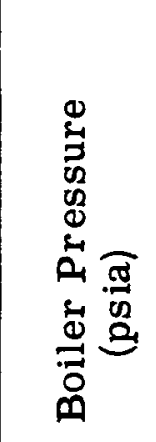 } & \multirow{2}{*}{ 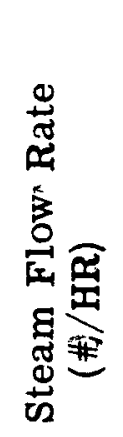 } & \multirow{2}{*}{ 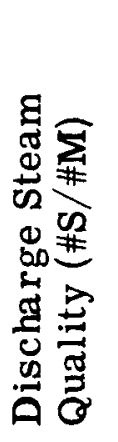 } & \multicolumn{2}{|c|}{$\begin{array}{c}\text { Gross Heater } \\
\text { Power }\end{array}$} & \multicolumn{2}{|c|}{$\begin{array}{l}\text { Uncorrected } \\
\text { Net Power }\end{array}$} & \multirow[b]{2}{*}{ 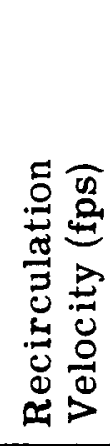 } \\
\hline & & & & KW & 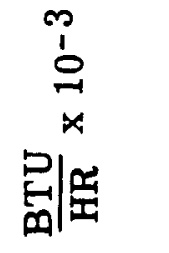 & KW & 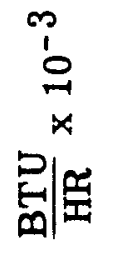 & \\
\hline+0.8 & 2207 & 495 & .95 & 108 & 367 & 79 & 270 & 5.9 \\
\hline 1.0 & 2207 & 485 & .96 & 107 & 366 & 78 & 266 & 5.9 \\
\hline 2.5 & 2217 & 485 & .97 & 109 & 372 & 78 & 266 & 5.8 \\
\hline 3.1 & 2207 & 478 & .97 & 109 & 371 & 77 & 264 & 5.8 \\
\hline 4.0 & 2217 & 485 & .97 & 110 & 374 & 78 & 266 & 6.0 \\
\hline 5.0 & 2227 & 490 & .92 & 109 & 372 & 75 & 254 & 6.3 \\
\hline 5.2 & 2187 & 519 & .88 & 109 & 372 & 77 & 264 & 6.3 \\
\hline \multicolumn{6}{|c|}{ Average } & 78 & 267 & \\
\hline \multicolumn{6}{|c|}{ Estimated Boiler Losses } & 2.5 & 8.5 & \\
\hline \multicolumn{6}{|c|}{ Estimated Loss from Safety Valve Leak } & 1 & 3.4 & \\
\hline \multicolumn{6}{|c|}{ Corrected Net Power } & 82 & 279 & \\
\hline
\end{tabular}




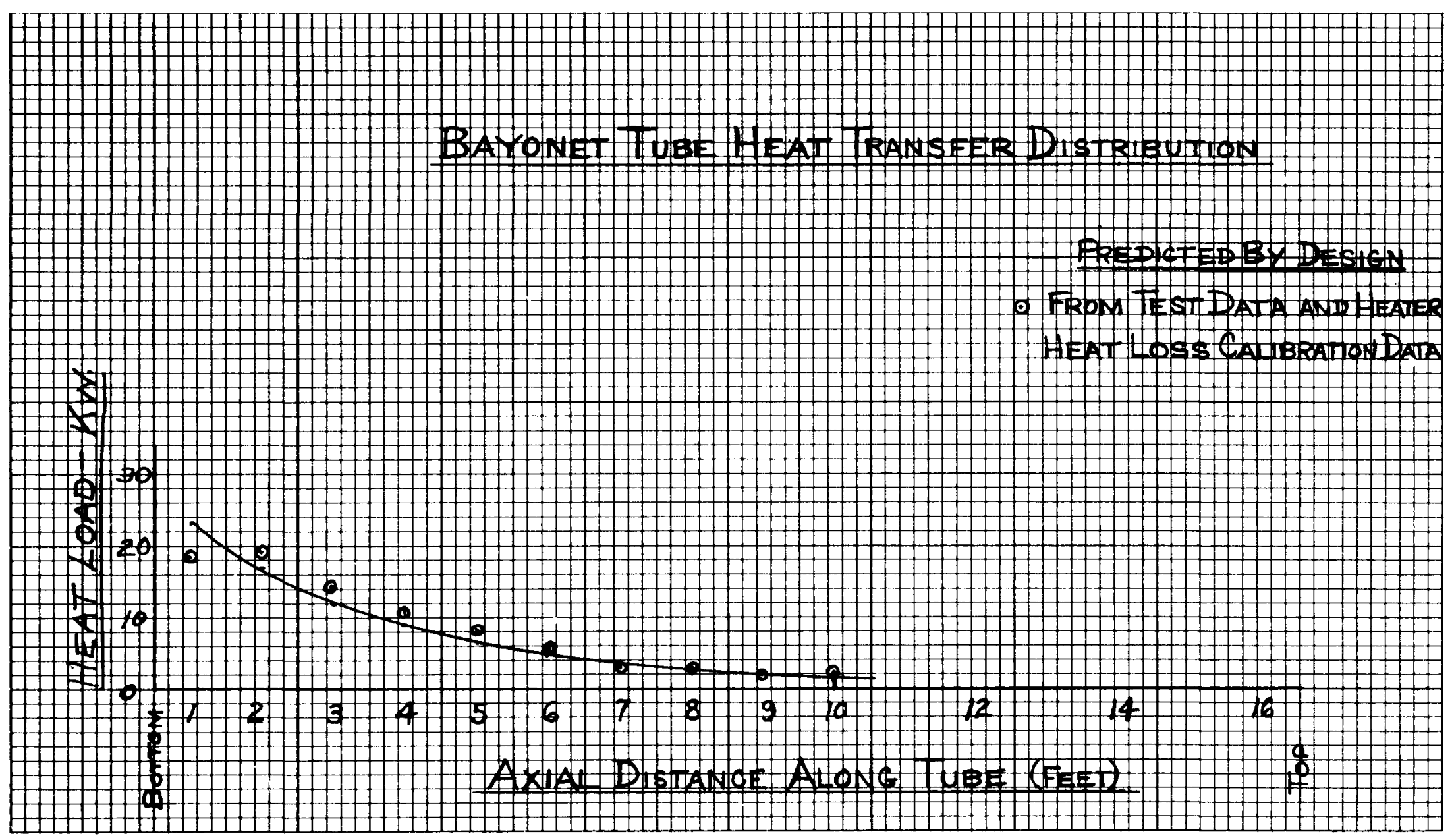

FIGURE 7-5 


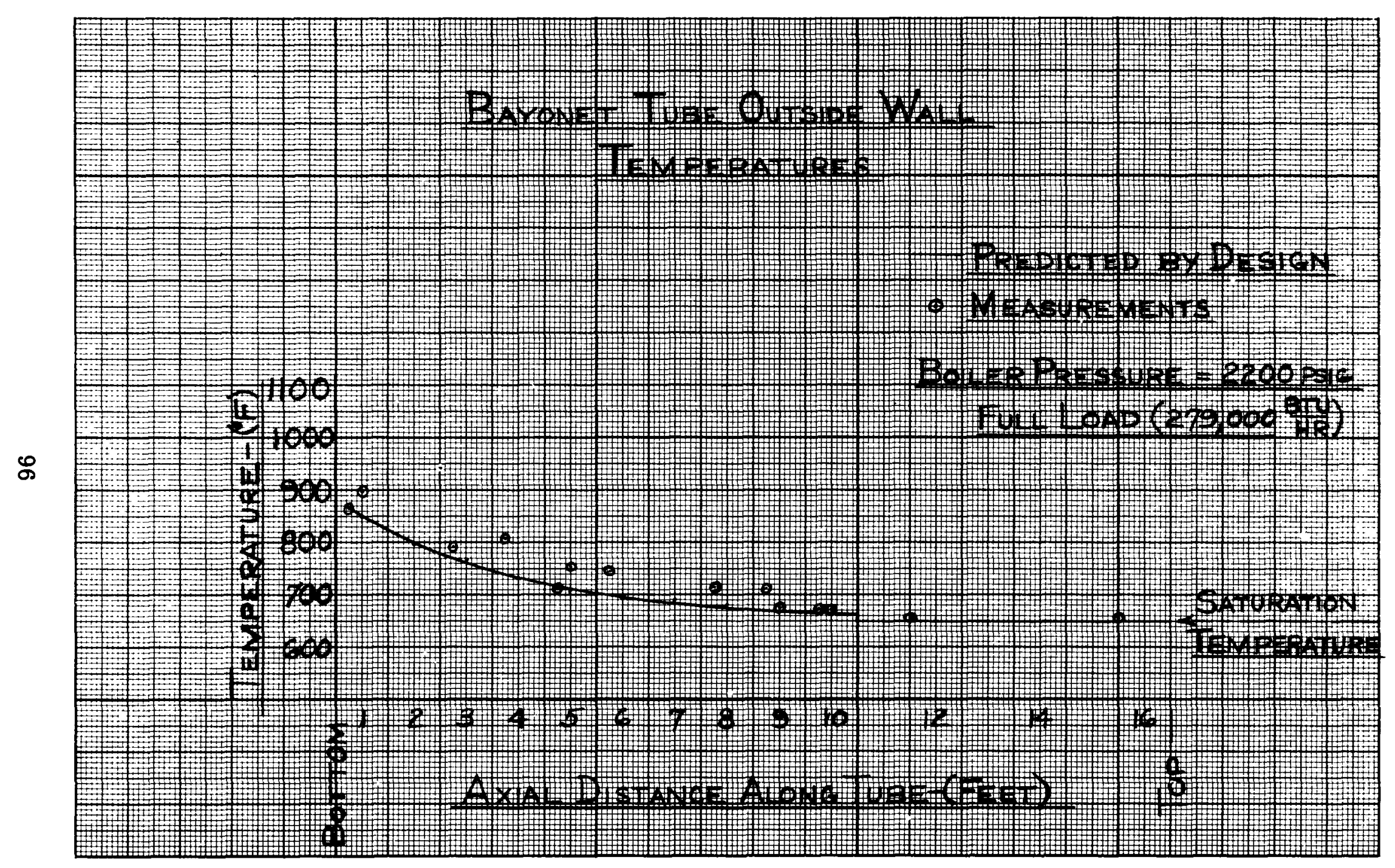

FIGURE 7-6 
The feedwater temperatures measured during the tests were 540$580^{\circ} \mathrm{F}$ (actual design temperature is $600^{\circ} \mathrm{F}$ ) and saturated water was leaving the drum downcomer (thermocouple indication). This accounts for the measured steam flow rate shown in Table 7-1 being smaller than the design value $(555 \mathrm{lb} / \mathrm{hr})$. The steam generated by the bayonet tube had to supply the additional preheat energy, compared to design preheat requirement, and therefore less steam was discharged. The energy per pound of steam discharged was larger than the design requir ement because of the additional preheat requirement. The combination of the smaller steam flow and larger energy transfer per pound of steam indicated that operation of the bayonet tube (below the bubble deck) as predicted by the design was obtained.

The operation at design conditions is further confirmed by the similiarity of the water velocity in the inner tube (measured by the pitot tube) and the analytical value of $6.2 \mathrm{ft} / \mathrm{sec}$.

\section{2}

At full load, the boiler water level was changed and the resultant effects are shown in Figure 7-7.

The change in steam flow and quality at an indicated boiler water level of approximately 5" above normal water level (normal water level is 12 " above the top of the bayonet tube) may be caused by flooding of the bubble deck and resultant change of water level in the drum above the bubble deck. Calculations accounting for the effective density of the steam-water mixture in the boiler drum show that the surface of the water-steam mixture may be approximately $30 \%$ higher than the indicated level. Based on these estimates, the surface of the water-steam mixture may have been at the bubble-deck level, a variation from design operation conditions.

7. 3

The average results of the chemical analysis of the boiler water (obtained by blowdown from drum of boiler) are:

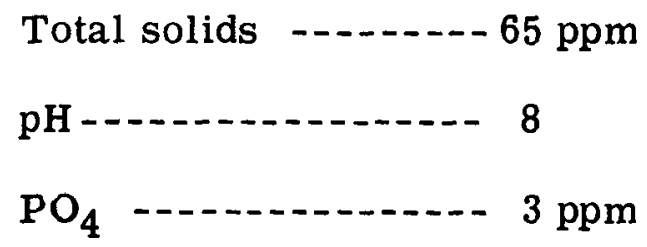




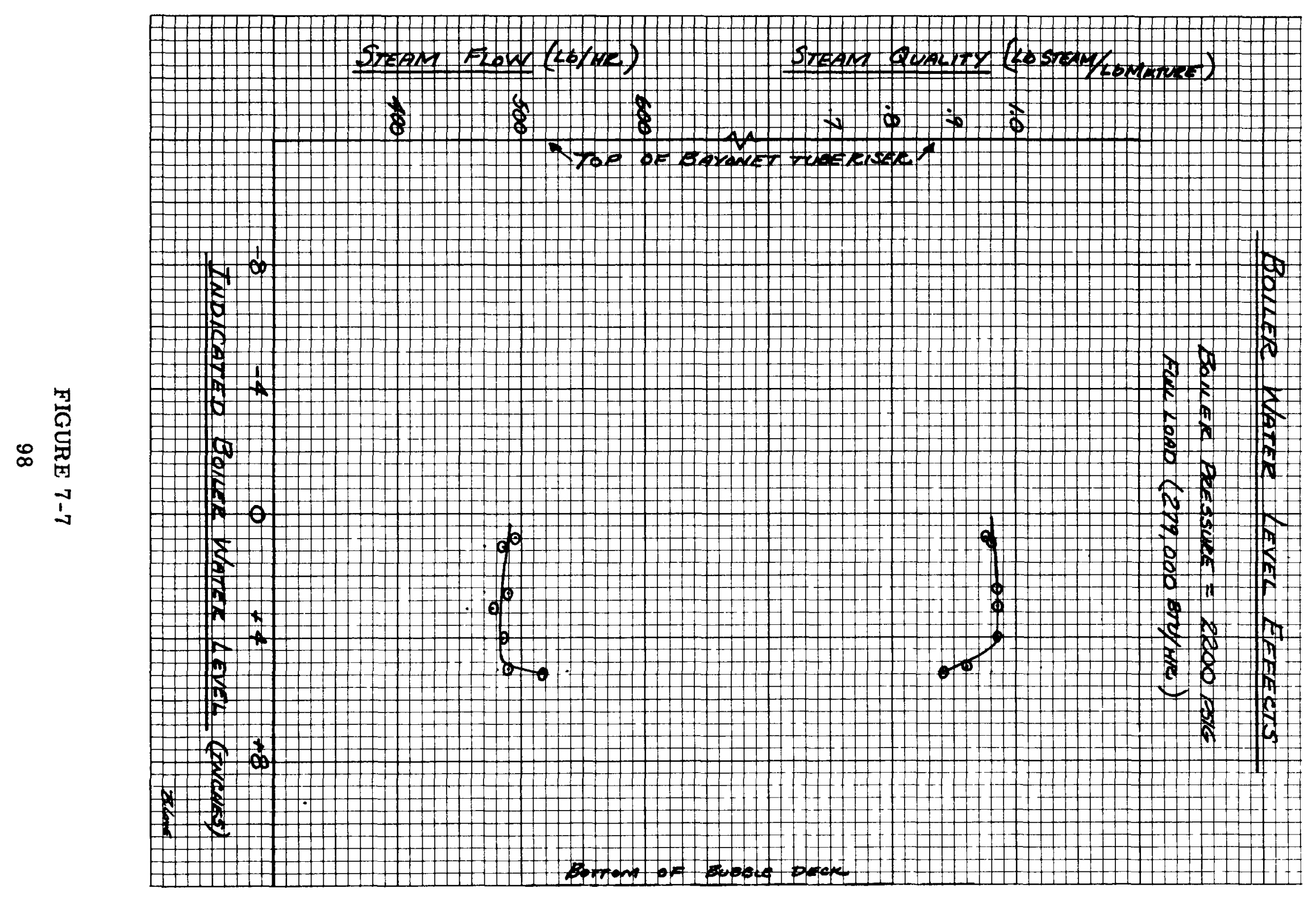




\section{CONCLUSION}

In general, the single bayonet tube test shows that the natural circulation boiler section of the steam generator design will operate as proposed in the preliminary design. Further, the test results give an indication that, with the design tube wall temperature and heat transfer distribution, the bayonet tube design is capable of generating the required steam load. Thus, the objective in performing this test has been satisfied. 


\section{APPENDIX}

\subsection{Sample Calculation}

The succeeding sections show the calculations for one test point.

\subsubsection{Steam Quality}

Data:

$$
\begin{array}{rlrl}
\text { T-FW-1 } & =170^{\circ} \mathrm{F} & \mathrm{h}_{\text {FW1 }}=143 \mathrm{BTU} / \mathrm{lb} \\
\text { P-FW-1 } & =\mathrm{P}-\mathrm{FW}-2=2200 \mathrm{psig} & & \\
& & & \\
\text { T-FW-2 } & =552^{\circ} \mathrm{F} & \mathrm{h}_{\mathrm{FW} 2}=552 \mathrm{BTU} / \mathrm{lb} \\
\text { P-FW-2 } & =2200 \mathrm{psig} & \\
\text { T-SD-2 } & =648^{\circ} \mathrm{F} & \mathrm{h}_{\mathrm{SD} 2}=692 \mathrm{BTU} / \mathrm{lb} \\
\text { P-SD-2 } & =2200 \mathrm{psig} & & \\
\text { P-SD-3 } & =2200 \mathrm{psig} & \mathrm{h}_{\mathrm{fSD} 1}=696 \mathrm{BTU} / \mathrm{lb} \\
& & \mathrm{h}_{\mathrm{gSD} 1}=423 \mathrm{BTU} / \mathrm{lb}
\end{array}
$$

9.1.1.1 Substituting these enthalpies into equation (6.1.1), neglecting the condenser heat loss (QCL) and the difference in flow rate of feedwater and steam because of a small safety valve leak,

$$
\begin{aligned}
\mathrm{h}_{\mathrm{SD1}} & =\mathrm{h}_{\mathrm{FW} 2}-\mathrm{h}_{\mathrm{FW} 1}+\mathrm{h}_{\mathrm{SD} 2} \\
& =552-143+692=1101 \mathrm{BTU} / \mathrm{lb} \\
\mathrm{X}_{\mathrm{SD} 1} & =\frac{\mathrm{h}_{\mathrm{SD} 1}-\mathrm{h}_{\mathrm{f}}}{\mathrm{h}_{\mathrm{fg}}}=\frac{1101-696}{423}=0.96 \frac{\mathrm{lb} . \text { steam }}{\text { lb. mixture }}
\end{aligned}
$$

9.1.1.2 The heat loss of the Condenser $\left(Q_{C L}\right)$ was estimated, by calculation of the heat transfer through the pipe insulation and natural convection film resistance, to be $800 \mathrm{BTU} / \mathrm{HR}$.

The steam leakage through the safety valve was estimated to be $6 \mathrm{lb} / \mathrm{hr}$, based on rate of change of the water level in the reservoir tank (Figure 7-3). This represents an approximately $1 \%$ larger feedwater flow rate compared to the steam flow rate. 
Recalculating the Steam Quality with these estimated energy losses,

$$
\begin{aligned}
h_{S D 1} & =\frac{W_{F W}}{W_{S D}}\left(h_{F W 2}-h_{F W 1}\right)+\frac{Q_{C L}}{W_{S D}}+h_{S D 2} \\
& =413+1+692=1106 / B T U / l b \\
x_{S D 1} & =\frac{h_{S D 1}-h_{f}}{h_{f g}}=\frac{1106-696}{423}=0.97 \frac{\text { lb steam }}{\text { lb mixtüre }}
\end{aligned}
$$

\subsubsection{Net Heat Transfer}

Data:

See Section 9.1

9.1.2.1 Substituting the enthalpies into equation 6.2.1 neglecting the boiler heat losses $\left(Q_{B L}\right)$ and the difference in flow rate of feedwater and steam because of the small safety valve leak,

$$
\begin{aligned}
Q_{N} & =W_{S D}\left(h_{S D 1}-h_{F W}\right) \\
& =485(1101-552)=266,000 \mathrm{BTU} / \mathrm{hr}
\end{aligned}
$$

9.1.2.2 The heat loss of the boiler (QBL) was estimated, by calculation of the heat transfer through the resistances (tube wall, insulation and natural connection film) of the various sections of the boiler including the boiler water level equalizing columns piping, to be 8,500 $\mathrm{BTU} / \mathrm{hr}$ 。 Recalculating the New Heat Transfer with this estimated loss and the estimated difference petween feedwater and steam rates,

$$
\begin{aligned}
Q_{N} & =W\left(h_{S D} 1-h_{F W 2}\right)+Q_{B L} \\
& =485(1106-552)+8500 \\
& =277,500 \mathrm{BTU} / \mathrm{hr}
\end{aligned}
$$

\subsubsection{Recirculation Velocity}

Data:

$$
\begin{aligned}
& \text { DP-BT-1 = 3.9 " } \mathrm{H}_{2} \mathrm{O} \quad \mathrm{v}_{\mathrm{f}}=1 / 62.4 \mathrm{ft}^{3} / \mathrm{lb} \\
& P-B D-1=2200 \text { psig } \quad v_{f}=1 / 37.3 \mathrm{ft}^{3} / \mathrm{lb} \\
& \mathrm{T}-\mathrm{BD}-3=657^{\circ} \mathrm{F}
\end{aligned}
$$


Substituting the differential pressure and specific volume into Equation 6.3.1,

$$
\begin{aligned}
& \mathrm{v}^{2}=2 \mathrm{~g} \frac{(\mathrm{DP})}{(12)}(62.4) \mathrm{v}_{\mathrm{f}} \\
& \mathrm{v}^{2}=(64.4) \frac{(3.9)}{(12)} \frac{(62.4)}{(37.3)}=35 \\
& \mathrm{~V}=5.9 \mathrm{fps}
\end{aligned}
$$

9.2 Equipment and Manufacturers

Equipment

1. Ammeters and Volmeters

2. C. A. T. Control Unit

3. Condensate Discharge Valve

4. Cooling Water Flowmeter

5. Feedwater Control Valve

6. Feedwater Temp. Control Valve

7. Heater (Electric-Radiant)

8. Pitot Tube-Thermocouple Ass'y.

9. Primary Feedwater Pump

10. Primary Pump By-pass Valve

11. Remote Reading Level Gage

12. Rotometers

13. Safety Valve

14. Secondary Feedwater Pump

15. Single Element Level Control

16. Steam Dump Valve

17. Thermocouples
Identification and/or

Serial Number

$1 / 2$ " type 530 Gismo $\# 10,000$ No.3112634

Model BT-Dial 107

1/2" type 530 Gismo $\# 10,000$ No. 3112636

1 " type 657D-\#6000

No. 3112633

Triplex-620-3

$1 / 2$ " type 530 Gismo $\# 10,000$

Cat. No。2Model 10A2735A 1970T-3/4" to 1 " $\left(5000 \mathrm{psi}-750^{\circ} \mathrm{F}\right)$ Set for $2450 \mathrm{psi}$

Model AV4-1-1/4" x 1-1/4"

1" type 470D-\#6000

Platinum-Platinum Rhodium Chromel-Alumel

\section{Manufacturer}

Weston Instruments

Leeds \& Nor thrup

Fisher Governor Co.

Buffalo Meter Co.

Fisher Governor Co.

Fisher Governor Co.

Trent, Inc。

Aero Research Instrument $\mathrm{Co}$.

John Bean Pump Div

Jerguson Gage \& Valve Co.

Fisher-Porter Co.

Manning, Maxwell

$\&$ Moore

Aurora Pump Division

Bailey Meter Co. Fisher Governor Co.

Pyrometer Co. of America, Inc., Aero Research Inst. Co. 


\section{BIBLIOGRAPHY}

1. Steam Generator Preliminary Design:

APAE No. 41, Volume II, Sections: C and D, Alco Products, Inc. submitted to United States Atomic Energy Commission。

2. Keenan, J.H. and Keyes, F.G., Thermodynamic Properties of Steam, First Edition, John Wiley and Sons, Inc. 
-

- 
SECTION 8

BAYONET TUBE WELD CAP TEST 


\section{BAYONET TUBE WELD CAP TEST}

TABLE OF CONTENTS

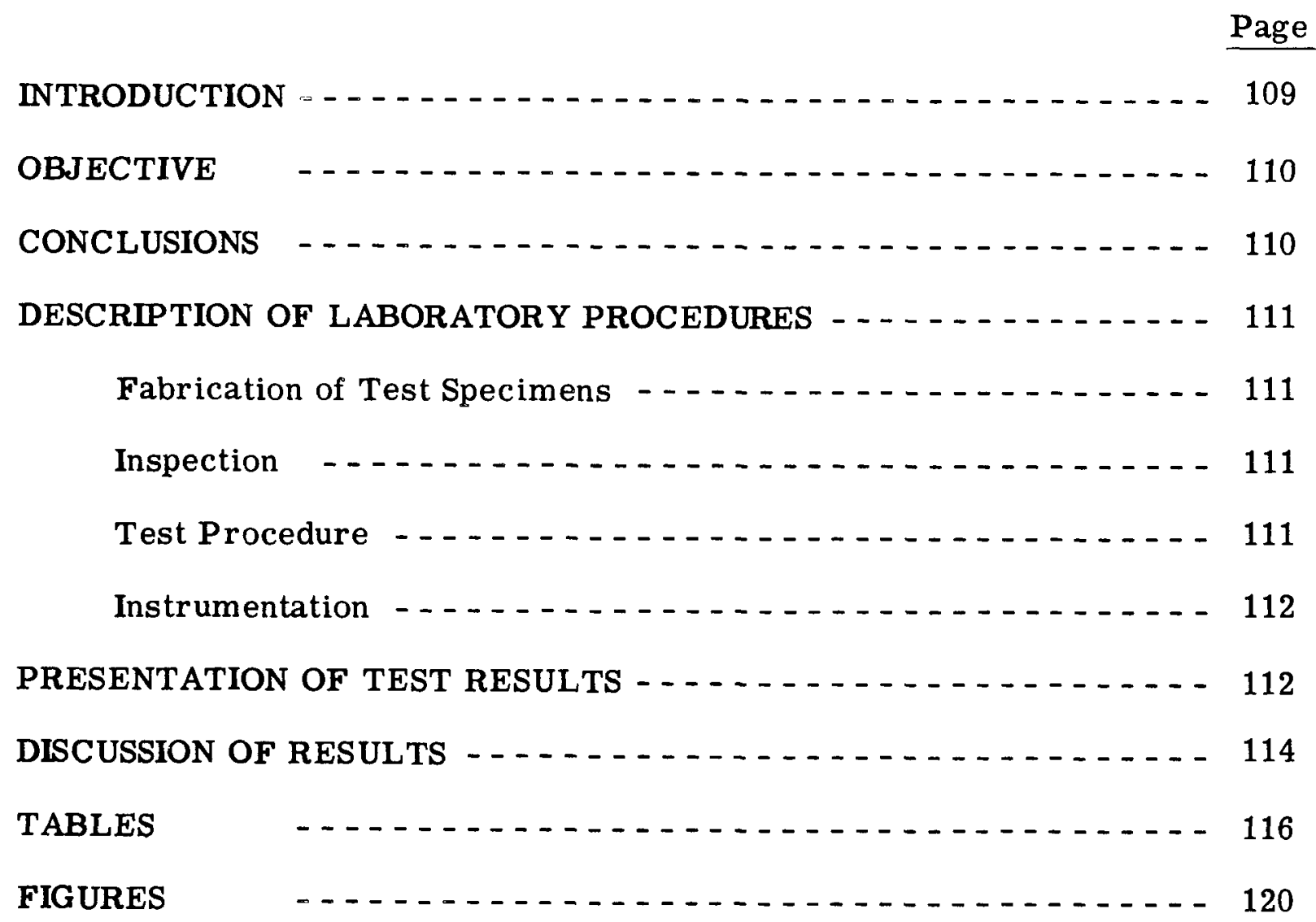




\section{LIST OF TABLES}

Page

Table 8-1 Data from Mill Test Report on Tubing Material 116

Table 8-2 Tube Dimensional Data 117

$\begin{array}{lll}\text { Table 8-3 Tube Welding Data } & 118\end{array}$

$\begin{array}{lll}\text { Table 8-4 Significant Test Data } & 119\end{array}$ 


\section{LIST OF FIGURES}

$\underline{\text { Page }}$

$\begin{array}{lll}\text { Figure } 8 \backsim 1 & \text { Bayonet Tube Weld Cap Test Weld Procedure } & 120\end{array}$

Figure 8-2 Prints from X-Ray Inspection Fllms for Specimen X-16 121

Figure 8-3 Bayonet Tube Weld Cap Test Cross Section of Pipe Enclosure Showing Heater and Test Specimen Location

122

Figure 8-4 Bayonet Tube Weld Cap Test Cross Section of Enclosure Showing Location of Test Assembly

Figure 8-5 Bayonet Tube Weld Cap Test Cross Section of Boiler Tube and Thermocouple and Pressure Assembly

Figure 8-6 Bayonet Tube Weld Cap Test Schematic of Heating and Instrumentation

Figure 8-7 Bayonet Tube Weld Cap Test Cross Section of Enclosure (End View) Showing Pressure Instrumentation and Piping

Figure 8-8 Ruptured Test Specimens

Figure 8-9 Prints from X-Ray Film of Weld Sections of Specimens T-28 and T-29

Figure 8-10 Prints from X-Ray Film of Weld Sections of Specimens $X-5$ and $X-16$

Figure 8-11 Photograph of Internal Surface of Welds from all Test Specimens

Figure 8-12 Weld Cross Sections of Specimens T-28 and T-29

Figure 8-13 Weld Cross Sections of Specimens X-5 and X-16

Figure 8-14 Short Time Tensile Strength Versus Temperature for 2-1/4\% Chromium-1\% Molybdenum Tubing Material

Figure 8-15 Steam Temperature Versus Pressure Heating Curves for Test Specimens 


\section{INTRODUCTION}

This is a final report on the research investigation for evaluation of the bayonet tube assembly end cap fabrication for the steam generator design described in APAE .78, Volume I.

This work was performed as part of the research and development program for the Sodium Components Design Project. 


\section{OBJECTIVE}

The primary objective of this program was to demonstrate the reli ability of boiler tube end cap fabrication for the bayonet tube boiler designed by ALCO Products, Incorporated, under United States Atomic Energy Commission Contract No. AT (11-1)-666.

Original objectives included compilation of temperature-rupture data to indicate the variance in quality of tube material, as well as the degree of premature failure caused by defective welds. These objectives were to be accomplished through a sufficient number of tests to allow statistical evaluation of results. Testing was terminated after completion of four tests because of a change in direction of the overall contract and obvious accomplishment of the primary test objective.

\section{CONCLUSIONS}

1. The welding procedure employed for end cap fabrication was satisfactory.

2. The X-ray inspection techniques which were utilized are completely satisfactory for indication of serious defects in the end cap welds.

3. The welded end cap on the boiler tube is completely reliable. It is extremely improbable that any boiler tube failure will initiate at an end cap weld which has passed inspection.

4. Temperature-rupture data on tubing which was tested are in good agreement with values reported in manufacturer's literature. 


\section{DESCRIPTION OF LABORATORY PROCEDURES}

\section{A. Fabrication of Test Specimens}

Test specimens were taken from two lengths of hot finish minimum wall Babcock and Wilcox Croloy 2-1/4 boiler tubing to ASTM Specification A-213, T22. Two specimens were tested from each of two tubes, representing two heats of material. The tubing size ordered was 2.000 inch $O$. D. X .220 inch minimum wall. Data from the mill test report are given in Table 8-1 sand dimensional data on individual test specimens are presented in Table 8-2. End caps were machined from 2-1/4\% chromium-1\% molybdenum bar stock to accommodate high pressure fittings required for temperature and pressure measurement. Weld caps were machined from 2 inch double extra-strong pipe weld caps. The caps were welded to a tube test specimen, approximately 26 inches in length, by the automatic inert gas shielded tungsten arc process, utilizing a consumable inert.

Details of the weld procedure are given in Figure 8-1 and Table 8-3.

The letter prefixes $\mathrm{T}$ and $\mathrm{X}$ assigned to specimen numbers represent the two heats of material from which specimens were tested.

B. Inspection

A double wall X-ray technique was used for inspection of weld quality. The film was placed on the outside of the tube, and the X-ray was taken at an angle through both walls. Only the wall closest to the film was focused for inspection. Three shots were taken of each weld to insure inspection of the complete weldment circumference.

Prints from the $X$-ray inspection films of specimen $X-16$ are shown in Figure 8-2 as an example. This weld was intentionally made porous by the welder. The porosity is very evident in film B of Figure 8-2. $\mathrm{Th}_{L} \mathrm{~S}$ weldment would have been rejected for service on the basis of inspection films. X-ray negatives were somewhat sharper than the prints shown $n$ Figure 8-2.

\section{Test Procedure}

The test specimen was filled with a measured quantity of water, and enough water was then withdrawn to leave a calculated weight of water per unit volume of test specimen. The calculated weight of water required was based on thermodynamic properties of steam at constant volume to give the pressure desired at the temperature desired. The desired rupture temperature was approximately $950^{\circ} \mathrm{F}$, the expected service temperature 
of the boiler tube end cap. The expected rupture pressure for this temperature was calculated by Barlow's formula, $P=\frac{2 S T}{D}$, using Babcock and Wilcox short time-high temperature tensile strength data for values of "S".

The test assembly is shown in Figure 8-3. The inner barrier was ten inch heavy carbon steel pipe. The heater section consisted of a four inch diameter tubular length of stainless steel, formed from 30 gage sheet material, and resistance heated with a 400 ampere $\mathrm{AC}$ welding generator. The test specimen end cap was bolted to a support plate which was held in position by a pipe flange. The specimen extended horizontally into the tubular heater section, with approximately a two inch clearance from the heater walls. This assembly was placed in an outer barrier, as shown in Figure 8-4.

The test specimen was instrumented and heated until rupture.

\section{Instrumentation}

A chromel-alumel thermocouple lead was tack welded to the inside of the tube test specimen prior to attachement of the weld cap. This thermocouple was located near the test weld on the finished test specimen. The thermocouple lead, with high temperature waterproof insulation, was extended through the $3 / 16$ inch drill hole in the tube end cap, at the other end of the test specimen. During assembly, this thermocouple lead was spliced to the open leads of a commercial thermocouple extending from a high pressure assembly. A second thermocouple extended from the high pressure assembly into the test specimen for measurement of steam temperature. Three additional thermocouples were attached to the outer wall of the test specimen. The thermocouple assembly and location of the thermocouples on the test specimen are shown in Figure 8-5. A schematic wiring diagram for the thermocouples is shown in Figure 8-6.

A high pressure tubing assembly extended from the tube end cap through a check valve to a $0-15000$ psi bourdon tube pressure gage, and to a Foxboro pressure recorder, calibrated for $10,000-25,000 \mathrm{psi}$. Figure 8-7 is a sketch showing the location of pressure instrumentation.

\section{PRESENTATION OF TEST RESULTS}

None of the tubes tested failed in the weld zone, and none of the failures extended into the weld zone. All failures were similar in appearance, as shown in Figure 8-8. 
Test specimens were fabricated in accordance with ALCO welding procedure specifications (Figure 8-1) prepared for this test program. The same specifications are to be applicable to boiler tube end cap fabrication for the steam generator. Specimens T-28 and T-29 were fabricated with welds of the highest quality attainable using these specifications. Defects were purposely incorporated in test welds for specimens $X-5$ and $X-16$, so as to represent the poorest quality welds. It was stipulated that these defective welds were to have a good cover pass, so that defects were not outwardly visible. Otherwise, the defects were to be of sufficient magnitude to cause premature failure of the test specimens.

Notations concerning weld quality were made by the welding engineer after completion of each weld. These notations are given in the "Remarks" column of Table 8-3.

Note that test welds (weld cap) on specimens T-28 and T-29 were considered good (marked as $\mathrm{OK}$ ). The test weld of specimen $\mathrm{X}-5$ contained a concave root and burn-through caused by excessive heat input to localized areas. The test weld of specimen X-16 contained porosity, tungsten inclusions, burn-through, and a concave root.

$X$-ray inspection of the test welds correlated with the quality of welds as judged and intended during fabrication. The test welds of specimens $X-5$ and $X-16$ definitely would have been rejected by Code standards.

After failure of the test specimens, the test welds were sectioned for further examination. Prints from X-ray film of the weld sections are presented in Figures 8-9 and 8-10. Figure 8-11 is a photograph of the internal surface of welds from all specimens. Photographs of weld cross sections are shown in Figures 8-12 and 8-13.

The weld quality obviously had no effect on failure of any of the test specimens. Even those welds which were purposely defected in an effort to cause failure at the weld $(X-5$ and $X-16)$ withstood the pressure which caused failure of the tube material. Table 8-1 indicates that the tensile strength of this tube material was well above the minimum allowable value of 60,000 psi.

Figure 8-14 is a comparison of the experimental bursting strength at rupture temperatures with short time high temperature tensile data reported in manufacturer's literature. A curve showing the ASME Boiler and Pressure Vessel Code allowable design stresses is included for comparison with rupture values. Experimental values for the ultimate stress were calculated by the formula,

$$
S=\frac{P(R o+1)}{2(\text { Ro }-1),} \text { where }
$$




$$
\begin{aligned}
\mathbf{P}= & \begin{array}{l}
\text { maximum test pressure developed in pounds } \\
\text { per square inch. }
\end{array} \\
\mathbf{R o}= & \text { ratio of tube outside diameter to tube inside } \\
& \text { diameter }(\mathbf{R o}<1.50) \\
\mathrm{S}= & \text { approximate bursting strength in pounds per } \\
& \text { square inch at the temperature of tube failure. }
\end{aligned}
$$

This relation has been verified many times by testing vessels to destruction and will correctly predict the bursting strength.

The heating curves for test specimens $T-29, X-5$ and $X-16$, showing pressure versus steam temperature during the heating period, are given in Figure 8-15. Constant volume lines, as constructed from Russian high pressure steam data, "Thermodynamic Properties of Water and Steam", by M.P. Vakalovitch, are included in the figure. Specimen X-5 developed a leak while the pressurizing fluid was in the compressed liquid state. The leak apparently sealed itself and the pressure rise occurred on a different constant volume line. No heating curve was constructed for specimen T-28, because of erroneous temperature and pressure data.

Significant test data are presented in Table 8-4.

\section{DISCUSSION OF RESULTS}

There is a reasonable explanation as to why the test specimens should not have failed at the weld zone. First, the weld deposit and heat affected zone are known to be of higher hardness than the tube material after the final stress relief heat treatment. Therefore, the weld zone must have somewhat greater ultimate strength than the tube. Secondly, the stresses resulting from internal pressure in the test specimen are only one half as great at the dead end of the weld cap as they are along the tube. The end of the weld cap is also thicker than the tube wall. Consequently, the end of the weld cap tends to remain rigid when the tube has started to yield. The tube growth with reduction of cross sectional area is less restrained in locations furthest from either end of the tube. If there were no material defects or other factors contributing to location of failure, it could, therefore, be expected that test specimen ruptures would occur near the middle of the tube. This was the case in three of the four ruptures, and the fourth occurred at a substantial distance from the rigid end. Thirdly, the rupture is caused by hoop stress, and originates as a longitudinal shear failure.

The importance of defects in a girth weld would be minimized for initiation of a longitudinal failure. 
The appearance of the fracture surface of the test specimens (Figure 8-8) is characteristic of bursting tests with a large amount of stored pressure energy available. The fracture initiated as a longitudinal shear fracture and suddenly changed into a cleavage crack proceeding at high velocity normal to the surface of the tube. A service failure due to creep would be expected to be of much smaller magnitude, with only a longitudinal fissure.

X-ray examination of the weldments ver if ied the weld quality as reported by the welder, and as shown by sectioning of welds after test. The demonstrated efficiency of inspection techniques and the low weld efficiency requirement for an end cap weld which will not initiate a service railure indicates that the boiler tube weld caps will be completely reliable in service.

Three of the experimental temperature-rupture points given in Figure 8-14 compare well with data quoted in manufacturer's literature. The rupture stress is slightly low for the other experimental point. The test specimen represented by this point, T-28, was taken from the end of a tube length, and some longitudinal seams were noted on the inside surface after failure. The somewhat early failure of this specimen may thus be due to defects in the tube material. Instrumentation was also faulty for this test and could account for the deviation from other experimental values. However, it is believed that the temperature and pressure values given for the rupture point are correct.

It is evident in Figure 8-14 that a large safety factor exists for Code allowable stresses, as compared to high temperature-short time tensile strength. However, this safety factor is less wiren considering creep strength, which is a controlling factor in determination of Code allowable stresses at high lemperature. 
TABLE 8-1

DATA FROM MILL TEST REPORT ON TUBING MATERIAL

\begin{tabular}{|c|c|c|c|c|c|c|c|c|c|}
\hline Item & Pcs. & $\begin{array}{l}\text { O. D. } \\
\text { In. }\end{array}$ & $\begin{array}{l}\text { Wall } \\
\text { In. }\end{array}$ & Length & Footage & $\begin{array}{c}\text { Ultimate } \\
\text { Strength } \\
\text { psi } \\
\end{array}$ & $\begin{array}{c}\text { Yield } \\
\text { Point } \\
\text { psi } \\
\end{array}$ & $\begin{array}{l}\text { \% Elong. } \\
\text { in } 2 \text { In. }\end{array}$ & Hardness \\
\hline 1 & 4 & 2. 0 & 0220 & Random & $85^{\prime} 9^{\prime \prime}$ & 70,100 & 51,400 & 56.0 & BHN 127-127 \\
\hline
\end{tabular}

5

\begin{tabular}{lcccccccc}
\multicolumn{8}{c}{ CHEMICAL ANALYSES } \\
Heat & $\begin{array}{c}\text { Letter } \\
\text { Designation }\end{array}$ & C. & $\underline{\text { Mn }}$ & S & $\underline{\mathrm{P}}$ & Si & $\underline{\mathrm{Cr}}$ & $\underline{\text { Mo }}$ \\
25869 & $\mathrm{X}$ & 0.11 & 0.50 & 0.015 & 0.017 & 0.37 & 2.25 & 1.01 \\
25832 & $\mathrm{~T}$ & 0.11 & 0.54 & 0.013 & 0.014 & 0.35 & 2.25 & 0.96
\end{tabular}


TABLE 8-2

TUBE DIMENSIONAL DATA

\begin{tabular}{|c|c|c|c|c|c|}
\hline Tube No. & $\begin{array}{l}\text { OD (in.) } \\
\text { (I.D.) Calc. }\end{array}$ & $\begin{array}{l}\text { A Wall } \\
\text { Thickness }\end{array}$ & $\begin{array}{l}\text { OD (in.) } \\
\text { (I.D.) Calc. }\end{array}$ & $\begin{array}{l}\text { Wall } \\
\text { Thickness }\end{array}$ & $\begin{array}{l}\text { MIDDLE } \\
\text { O.D. (in.) }\end{array}$ \\
\hline \multirow[t]{4}{*}{$\mathrm{T}-28$} & $\begin{array}{l}1.992 \\
(1.477) \\
\end{array}$ & $\begin{array}{l}.258 \\
.257 \\
\end{array}$ & $\begin{array}{l}1.994 \\
(1.489) \\
\end{array}$ & $\begin{array}{l}.248 \\
.257 \\
\end{array}$ & 1.987 \\
\hline & $\begin{array}{l}1.997 \\
(1.472) \\
\end{array}$ & $\begin{array}{r}.266 \\
.259 \\
\end{array}$ & $\begin{array}{l}1.997 \\
(1.469) \\
\end{array}$ & $\begin{array}{l}.264 \\
.264 \\
\end{array}$ & 1.993 \\
\hline & $\begin{array}{l}1.991 \\
(1.458) \\
\end{array}$ & $\begin{array}{l}.256 \\
.277 \\
\end{array}$ & $\begin{array}{l}1.990 \\
(1.470)\end{array}$ & $\begin{array}{l}.262 \\
.258 \\
\end{array}$ & \\
\hline & $\begin{array}{l}1.994 \\
(1.456) \\
\end{array}$ & $\begin{array}{l}.264 \\
.274 \\
\end{array}$ & $\begin{array}{l}1.996 \\
(1.486) \\
\end{array}$ & $\begin{array}{l}.256 \\
.254 \\
\end{array}$ & \\
\hline \multirow[t]{4}{*}{$T-29$} & $\begin{array}{l}1.995 \\
(1.473) \\
\end{array}$ & $\begin{array}{l}.263 \\
.259 \\
\end{array}$ & $\begin{array}{l}1.997 \\
(1.478) \\
\end{array}$ & $\begin{array}{r}.257 \\
.262 \\
\end{array}$ & 1.992 \\
\hline & $\begin{array}{l}1.993 \\
(1.480) \\
\end{array}$ & $\begin{array}{l}.251 \\
.262 \\
\end{array}$ & $\begin{array}{l}1.994 \\
(1.479) \\
\end{array}$ & $\begin{array}{l}.257 \\
.258 \\
\end{array}$ & 1.999 \\
\hline & $\begin{array}{l}1.993 \\
(1.489) \\
\end{array}$ & $\begin{array}{l}.251 \\
.253 \\
\end{array}$ & $\begin{array}{l}1.997 \\
(1.489) \\
\end{array}$ & $\begin{array}{r}.253 \\
.255 \\
\end{array}$ & \\
\hline & $\begin{array}{l}1.989 \\
(1.476)\end{array}$ & $\begin{array}{l}.253 \\
.260\end{array}$ & $\begin{array}{l}1.993 \\
(1.478) \\
\end{array}$ & $\begin{array}{l}.251 \\
.264 \\
\end{array}$ & \\
\hline \multirow[t]{4}{*}{$X-5$} & $\begin{array}{l}1.989 \\
(1.497)\end{array}$ & $\begin{array}{r}.249 \\
.243 \\
\end{array}$ & $\begin{array}{l}1.986 \\
(1.491)\end{array}$ & $\begin{array}{l}.244 \\
.251 \\
\end{array}$ & 1.991 \\
\hline & $\begin{array}{l}1.992 \\
(1.500) \\
\end{array}$ & $\begin{array}{l}.246 \\
.246 \\
\end{array}$ & $\begin{array}{l}1.989 \\
(1.500) \\
\end{array}$ & $\begin{array}{l}.244 \\
.245 \\
\end{array}$ & 1.989 \\
\hline & $\begin{array}{l}1.990 \\
(1.518) \\
\end{array}$ & $\begin{array}{r}.234 \\
.238 \\
\end{array}$ & $\begin{array}{l}1.994 \\
(1.511) \\
\end{array}$ & $\begin{array}{l}.244 \\
.239 \\
\end{array}$ & \\
\hline & $\begin{array}{l}1.986 \\
(1.499) \\
\end{array}$ & $\begin{array}{r}.242 \\
.245 \\
\end{array}$ & $\begin{array}{l}1.991 \\
(1.499) \\
\end{array}$ & $\begin{array}{r}.251 \\
.241 \\
\end{array}$ & \\
\hline \multirow[t]{4}{*}{$x-16$} & $\begin{array}{l}1.996 \\
(1.505) \\
\end{array}$ & $\begin{array}{l}.247 \\
.244 \\
\end{array}$ & $\begin{array}{l}1.993 \\
(1.498) \\
\end{array}$ & $\begin{array}{r}.246 \\
.249 \\
\end{array}$ & 1.999 \\
\hline & $\begin{array}{l}1.999 \\
(1.512) \\
\end{array}$ & $\begin{array}{r}.250 \\
.237 \\
\end{array}$ & $\begin{array}{l}1.989 \\
(1.494) \\
\end{array}$ & $\begin{array}{l}.248 \\
.247 \\
\end{array}$ & \multirow[t]{3}{*}{1.992} \\
\hline & $\begin{array}{l}1.990 \\
(1.494) \\
\end{array}$ & $\begin{array}{l}.241 \\
.255 \\
\end{array}$ & $\begin{array}{l}1.992 \\
(1.507)\end{array}$ & $\begin{array}{r}239 \\
.246 \\
\end{array}$ & \\
\hline & $\begin{array}{l}1.986 \\
(1.492)\end{array}$ & $\begin{array}{l}.248 \\
.246\end{array}$ & $\begin{array}{l}1.992 \\
(1.502)\end{array}$ & $\begin{array}{l}.249 \\
.241\end{array}$ & \\
\hline
\end{tabular}


TABLE 8-3

TUBE WELDING DATA

\begin{tabular}{|c|c|c|c|c|c|c|c|}
\hline Tube No. & Cap & $\begin{array}{l}\text { Pass } \\
\text { No. }\end{array}$ & Current & Volts & $\begin{array}{l}\text { Travel } \\
\text { Speed }\end{array}$ & Preheat & Remarks \\
\hline $\mathrm{T}-28$ & $\begin{array}{l}\text { End } \\
\text { End } \\
\text { Weld } \\
\text { Weld }\end{array}$ & $\begin{array}{l}1 \\
2-6 \\
1 \\
2-6\end{array}$ & $\begin{array}{l}115-120 \\
175-180 \\
115-120 \\
175-180\end{array}$ & $\begin{array}{l}10-11 \\
12-13 \\
10-11 \\
12-13\end{array}$ & $\begin{array}{l}3 \mathrm{~min} / \mathrm{rev} \text {. } \\
44 \mathrm{sec} / \mathrm{rev} \text {. } \\
3 \mathrm{~min} / \mathrm{rev} \text {. } \\
44 \mathrm{sec} / \mathrm{rev} .\end{array}$ & $\begin{array}{l}320 \\
340 \\
330 \\
340\end{array}$ & $\begin{array}{l}\text { OK } \\
\text { OK } \\
\text { OK } \\
\text { OK } 2 \text { CFH backing. } \\
\text { OK } \\
2 \text { CFH backing. }\end{array}$ \\
\hline $\mathrm{T}-29$ & $\begin{array}{l}\text { End } \\
\text { End } \\
\text { Weld } \\
\text { Weld }\end{array}$ & $\begin{array}{l}1 \\
2-6 \\
1 \\
2-6\end{array}$ & $\begin{array}{l}115-120 \\
175-180 \\
115-120 \\
175-180\end{array}$ & $\begin{array}{l}10-11 \\
12-13 \\
10-11 \\
12-13\end{array}$ & $\begin{array}{l}3 \mathrm{~min} / \mathrm{rev} \text {. } \\
44 \mathrm{sec} / \mathrm{rev} \text {. } \\
3 \mathrm{~min} / \mathrm{rev} . \\
44 \mathrm{sec} / \mathrm{rev} .\end{array}$ & $\begin{array}{l}320 \\
310 \\
330 \\
340\end{array}$ & $\begin{array}{l}2 \mathrm{CFH} \text { backing. } \\
2 \mathrm{CFH} \text { backing. }\end{array}$ \\
\hline$X-5$ & $\begin{array}{l}\text { End } \\
\text { End } \\
\text { Weld } \\
\text { Weld }\end{array}$ & $\begin{array}{l}1 \\
2-6 \\
1 \\
2-6\end{array}$ & $\begin{array}{l}115=120 \\
175-180 \\
115=120 \\
170-180\end{array}$ & $\begin{array}{l}10-11 \\
12-13 \\
10-11 \\
12-13\end{array}$ & $\begin{array}{l}3 \mathrm{~min} / \mathrm{rev} . \\
44 \mathrm{sec} / \mathrm{rev} . \\
3 \mathrm{~min} / \mathrm{rev} . \\
44 \mathrm{sec} / \mathrm{rev} .\end{array}$ & $\begin{array}{l}310 \\
330 \\
310 \\
300\end{array}$ & $\begin{array}{l}\text { OK } \\
\text { OK } \\
\text { concave root } 10) \mathrm{CFH} \text { backing. B. T. } \\
\text { OK } \quad 20)\end{array}$ \\
\hline$\times 16$ & $\begin{array}{l}\text { End } \\
\text { End } \\
\text { Weld } \\
\text { Weld }\end{array}$ & $\begin{array}{l}1 \\
2-6 \\
1 \\
2-6\end{array}$ & $\begin{array}{l}115-120 \\
175-180 \\
115-120 \\
170=175\end{array}$ & $\begin{array}{l}10-11 \\
12-13 \\
10-11 \\
12-13\end{array}$ & $\begin{array}{l}3 \mathrm{~min} / \mathrm{rev} \\
44 \mathrm{sec} / \mathrm{rev} \text {. } \\
3 \mathrm{~min} / \mathrm{rev} \text {. } \\
44 \mathrm{sec} / \mathrm{rev} .\end{array}$ & $\begin{array}{l}310 \\
340 \\
\\
320\end{array}$ & $\begin{array}{l}\text { OK } \\
\text { OK } \\
\begin{array}{l}\text { 10) } \\
\text { B. } T \text {. concave root - tung.incl. root } \begin{array}{r}15) \\
2)\end{array}\end{array} \\
\text { Possible por tung contam. Pass } \# 6\end{array}$ \\
\hline
\end{tabular}


TABLE 8-4

SIGNIFICANT TEST DATA

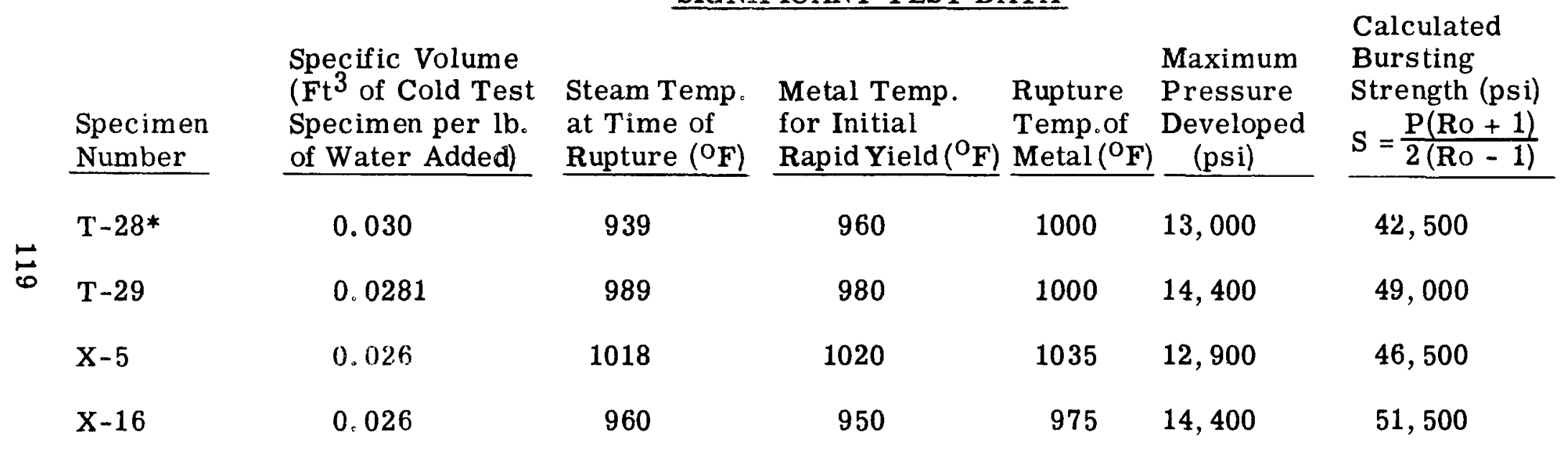

* Temperature and pressure data on Specimen T-28 may be in error 


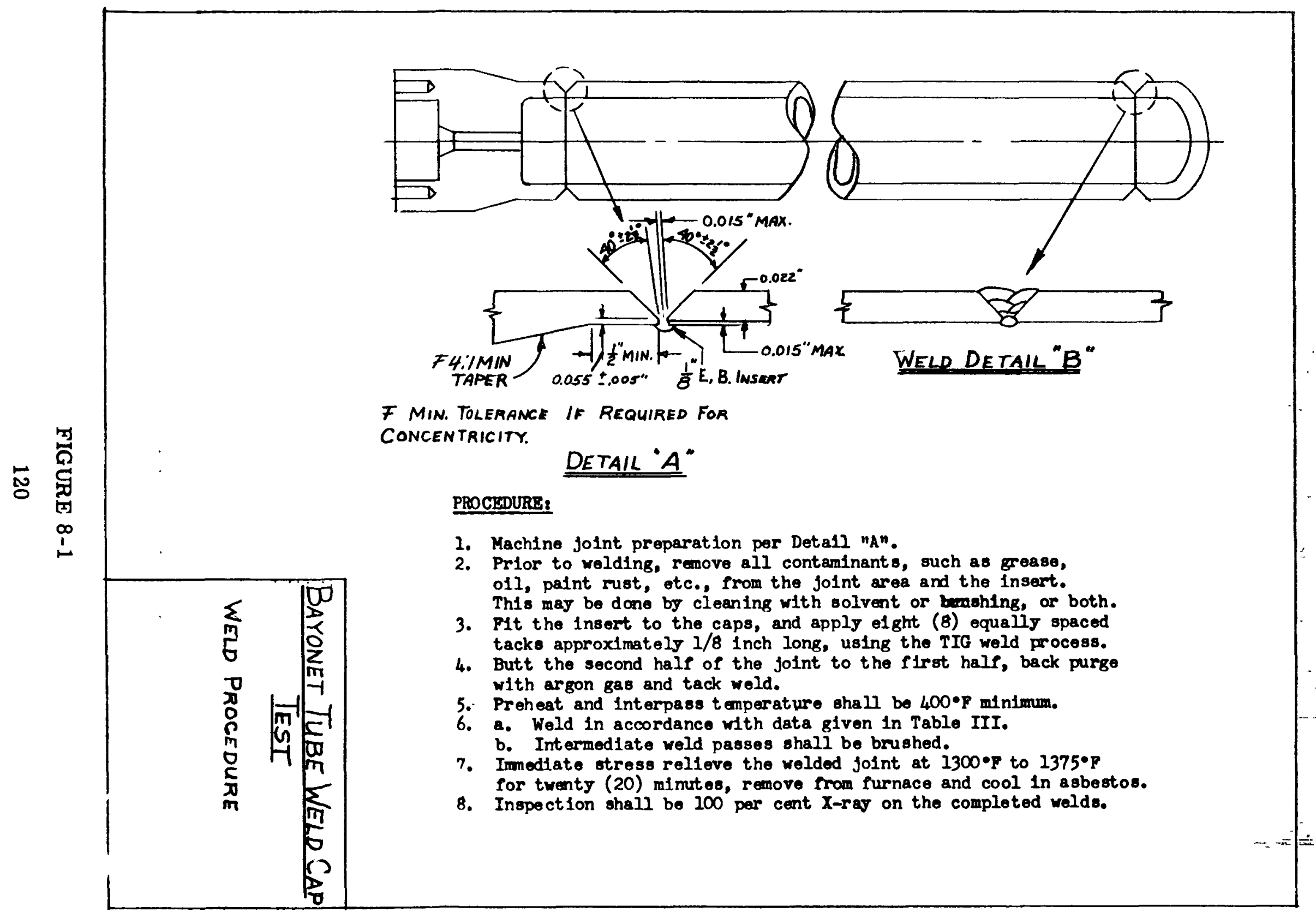



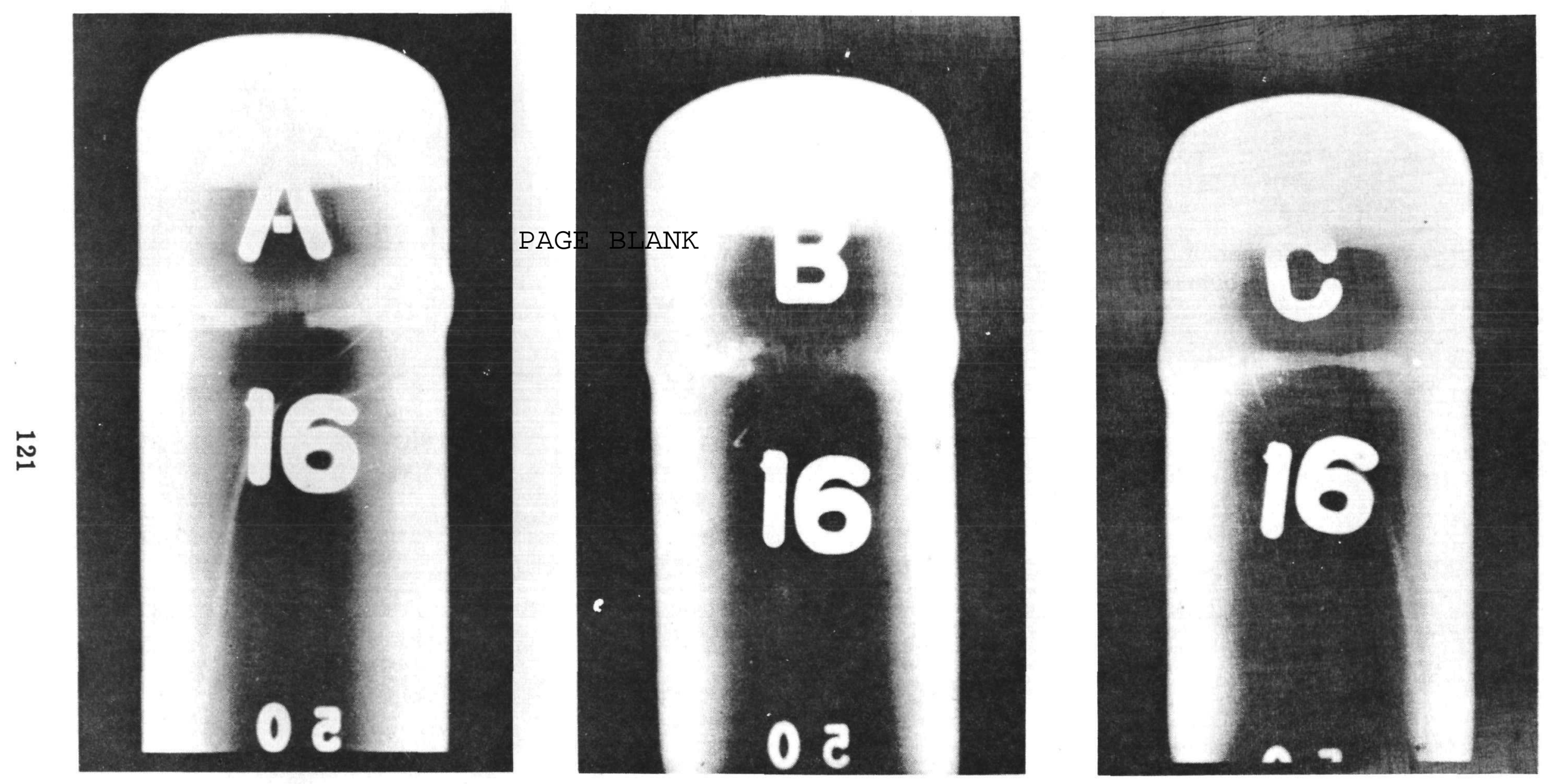

FIGURE 8-2

PRINTS FROM X-RAY INSPECTION FILMS FOR SPECIMEN X-16

Note porosity appearing in Film B 


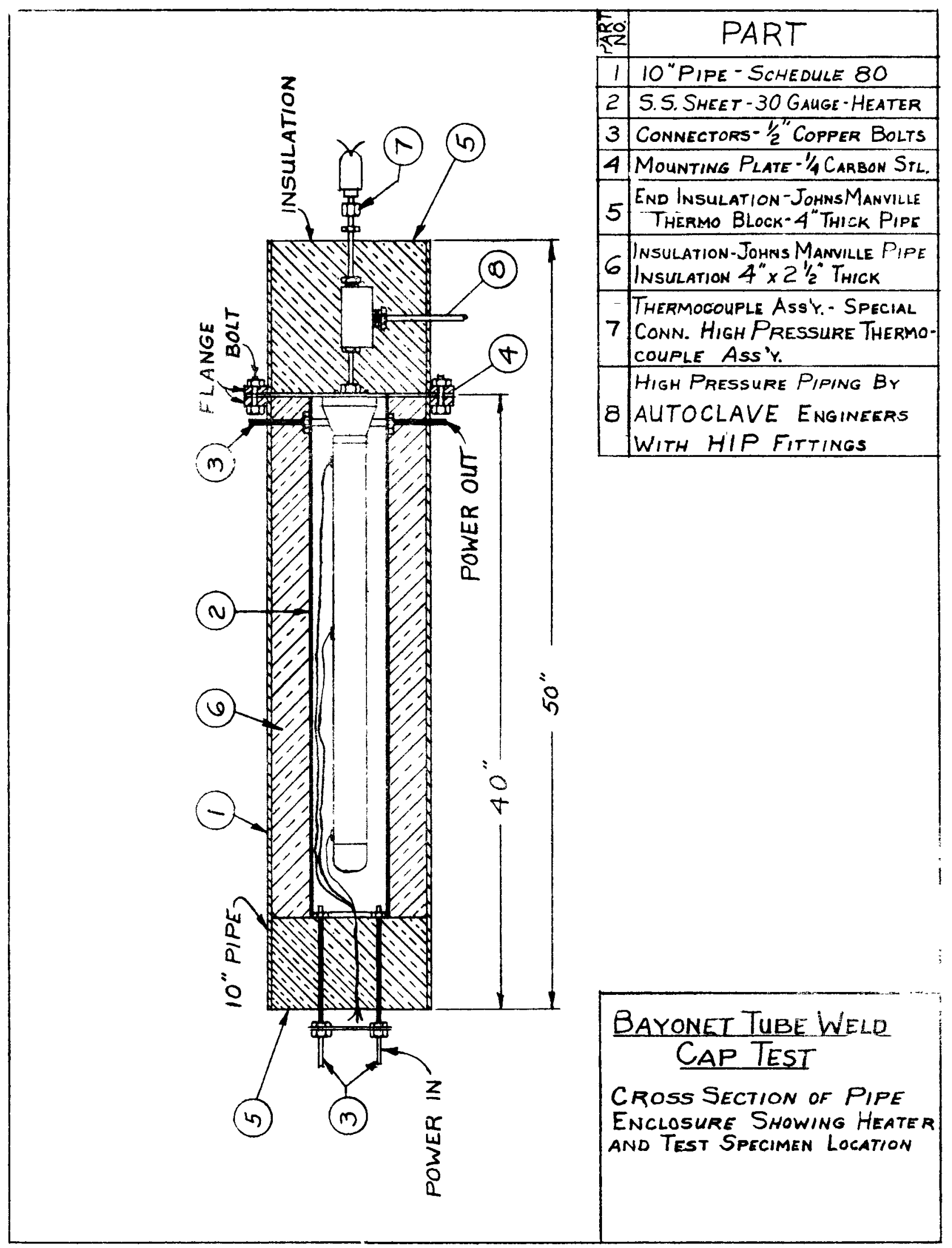

FIGURE 8-3 


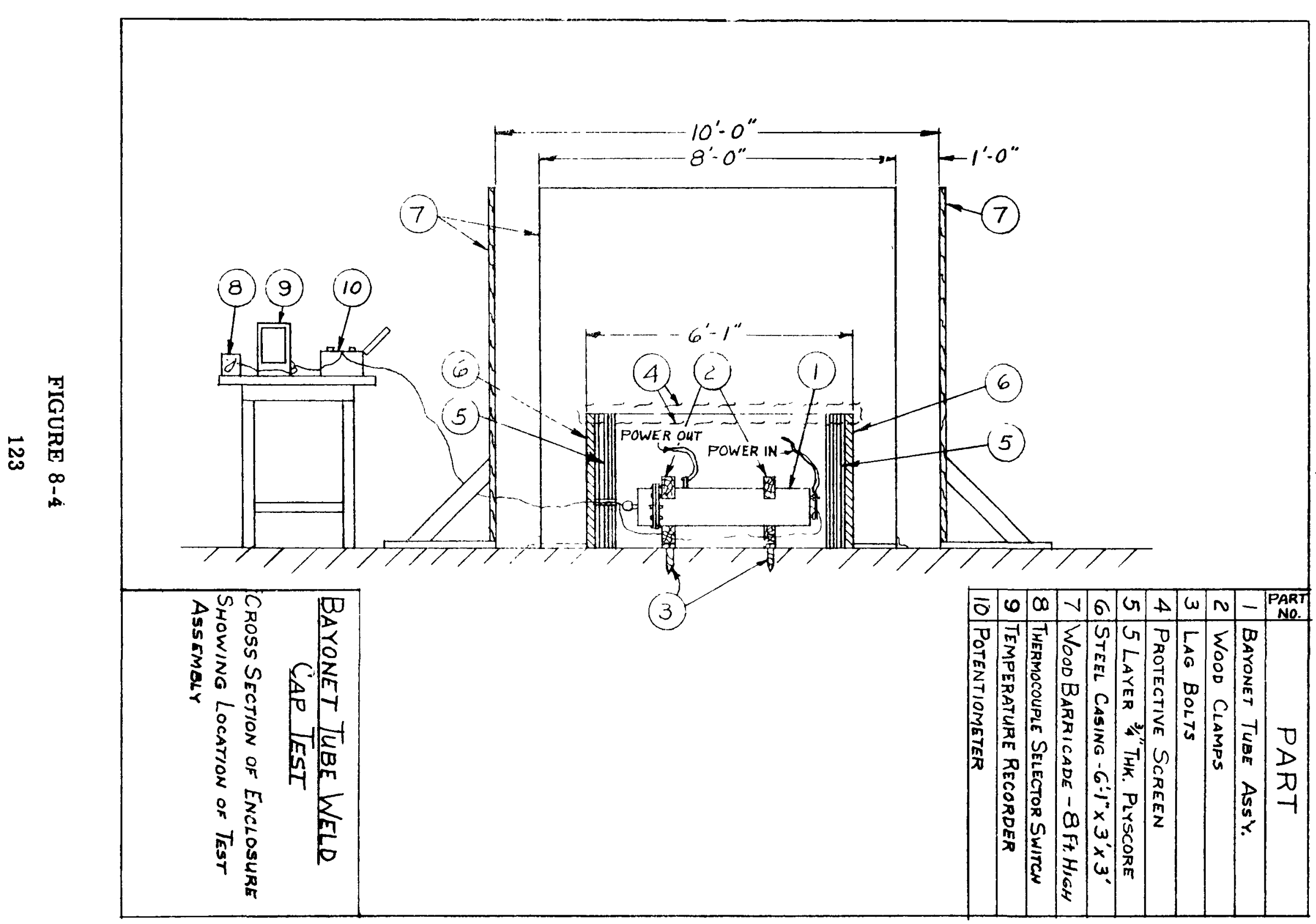




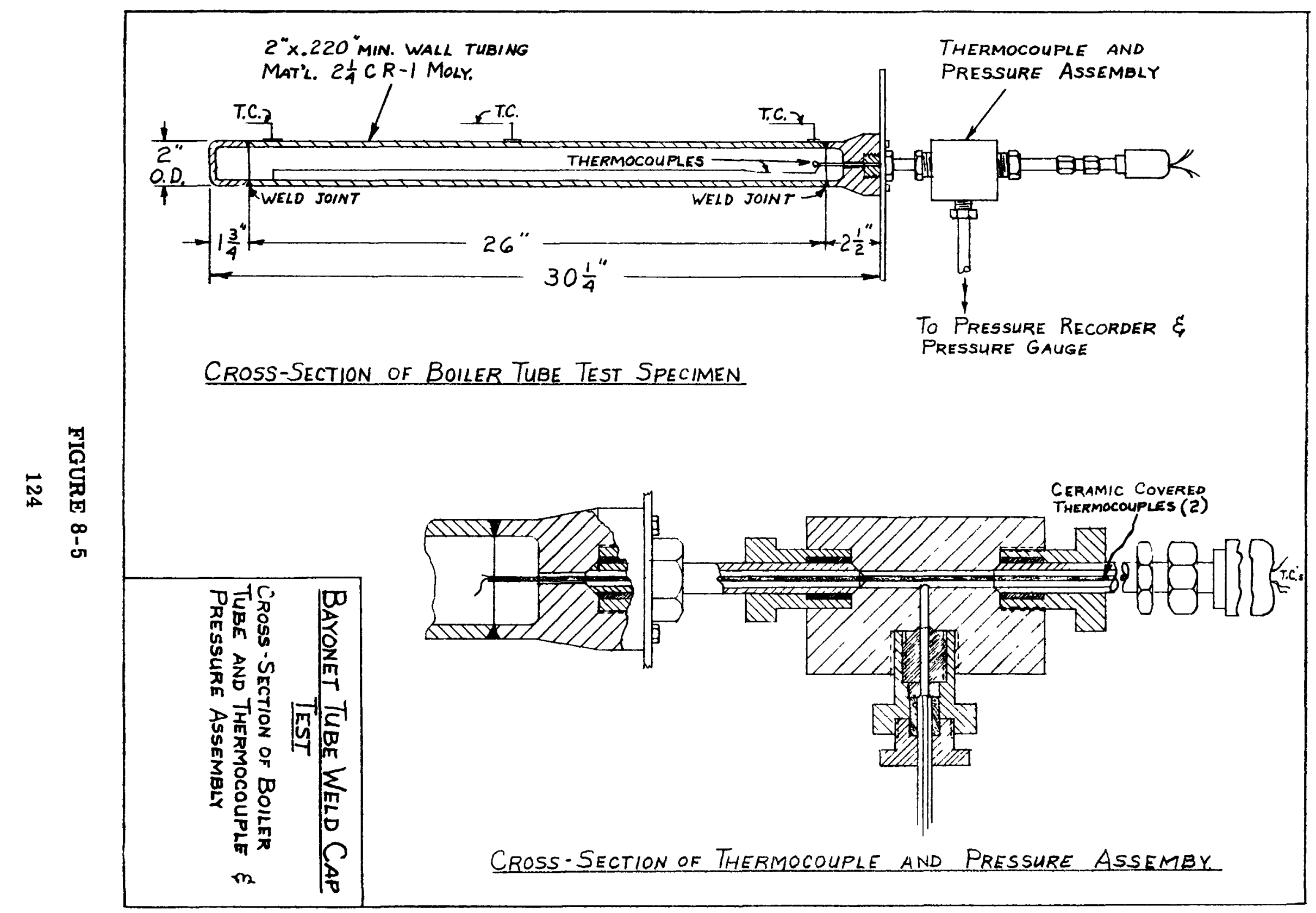




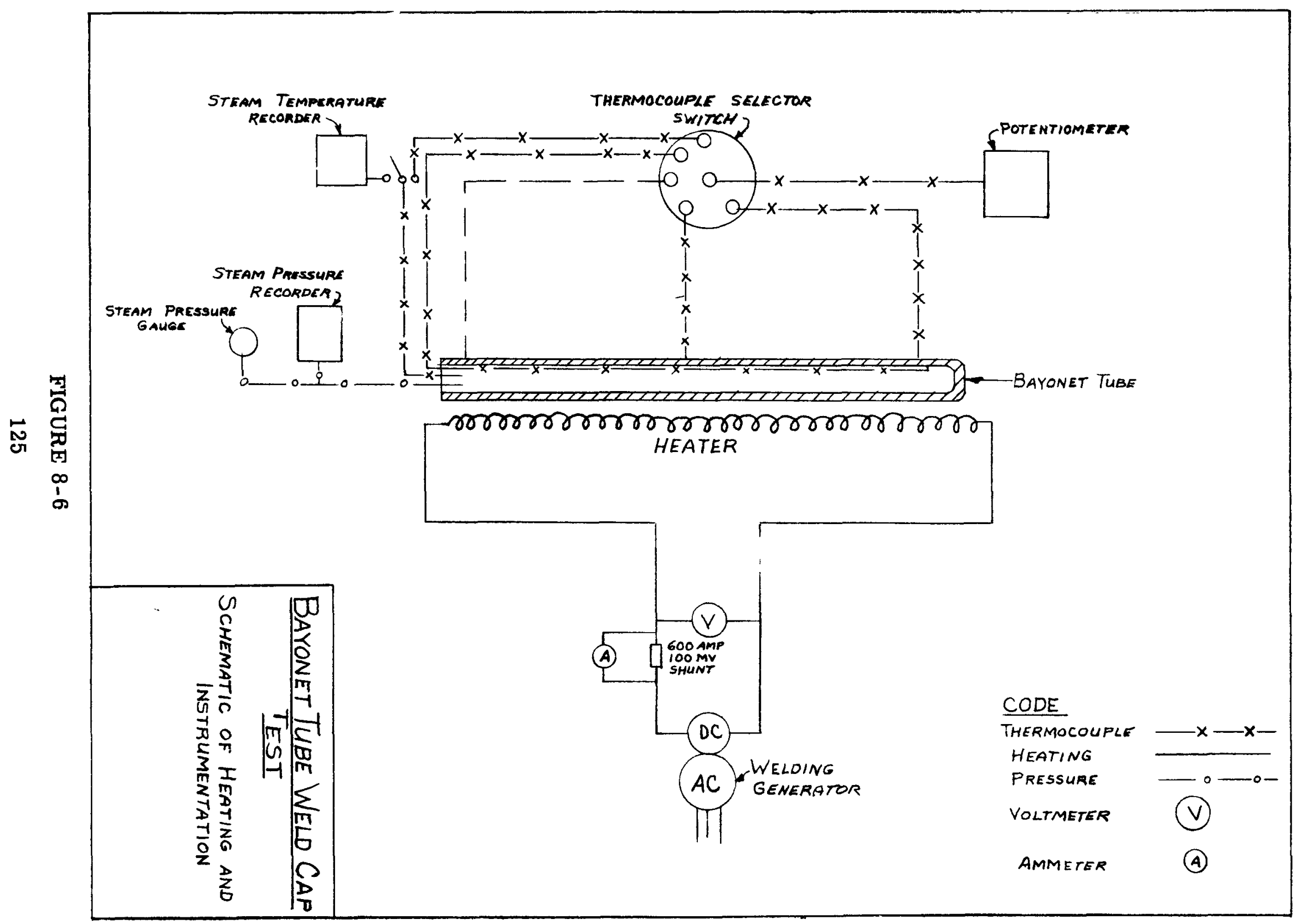




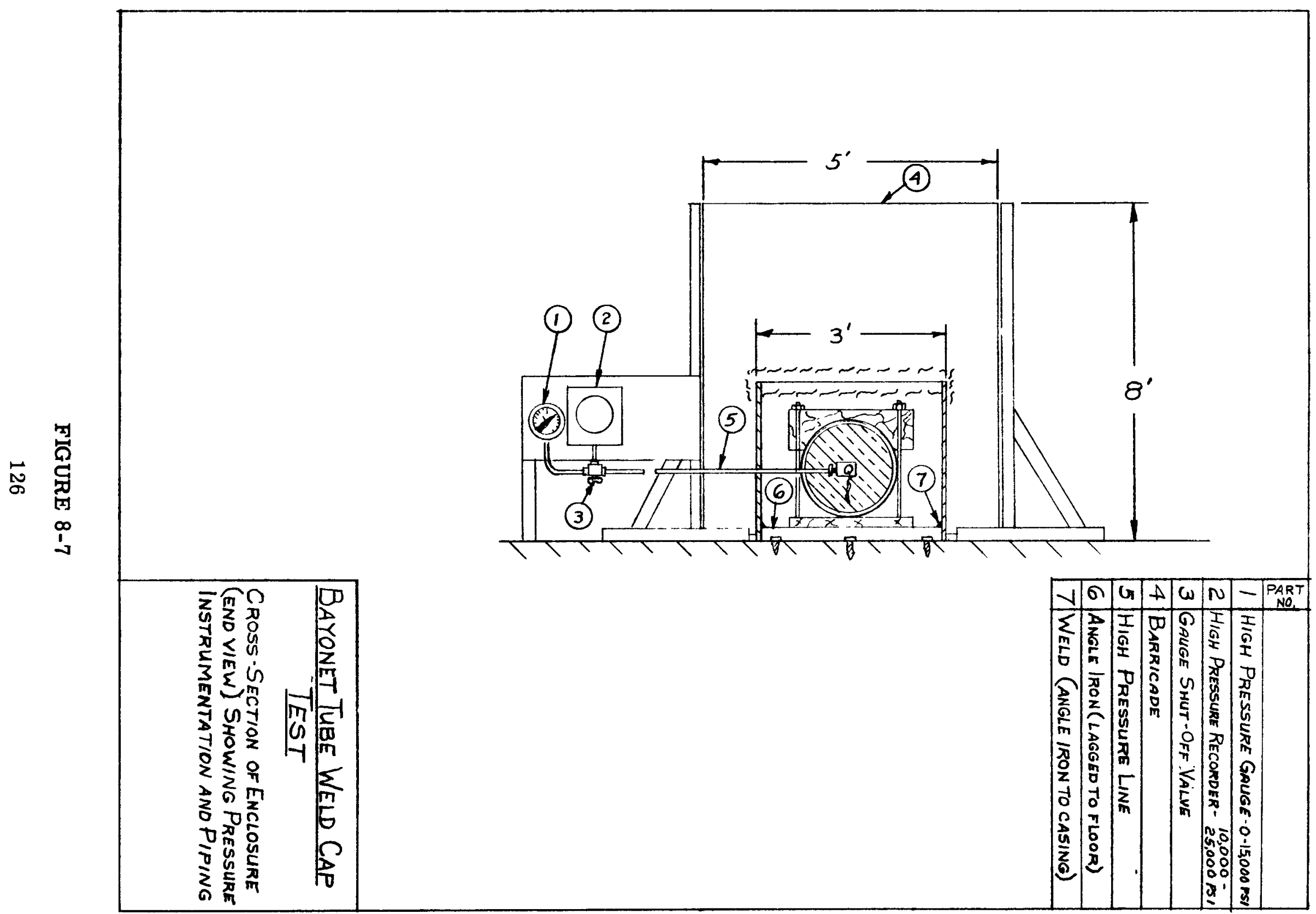



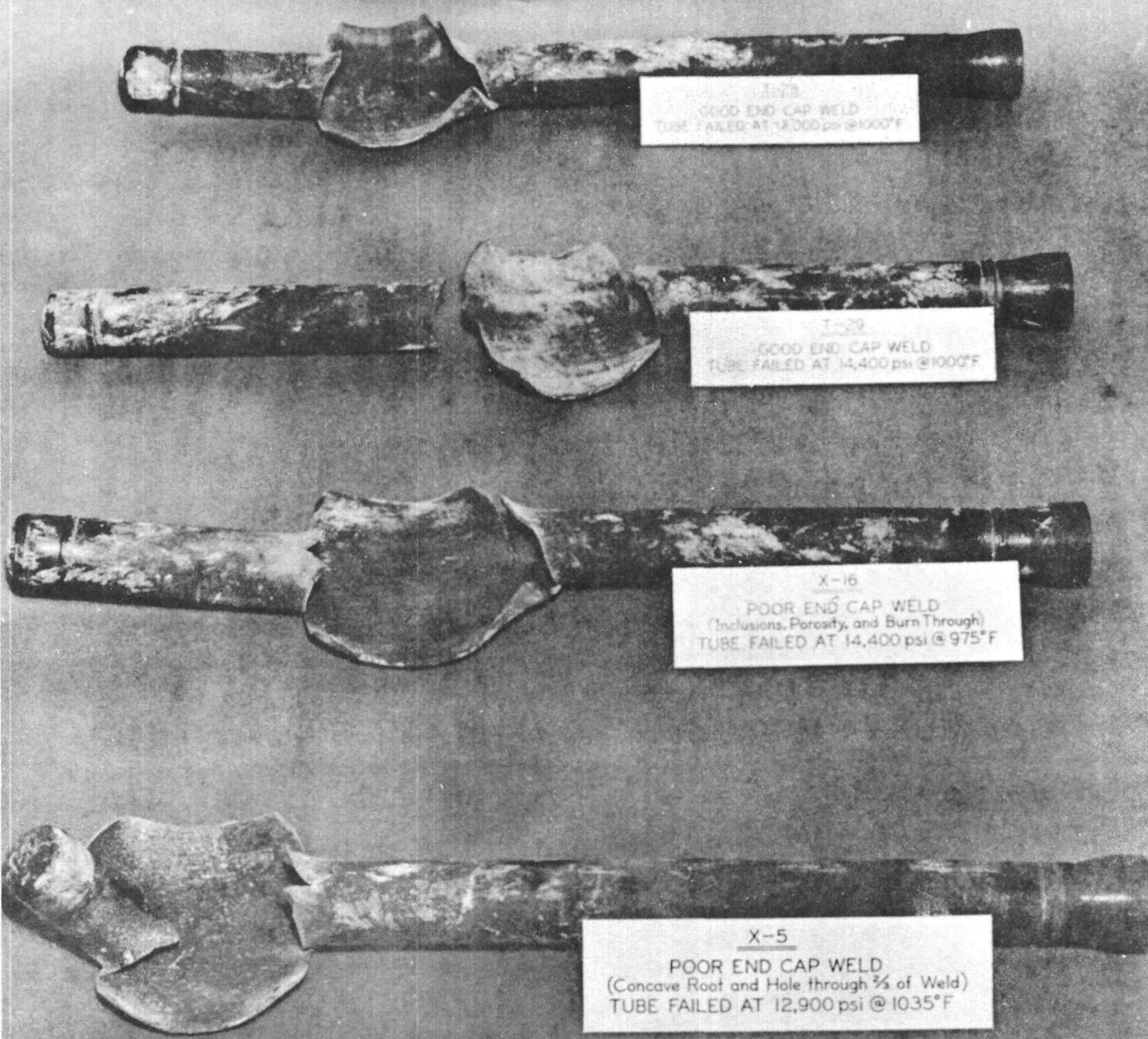

FIGURE 8-8

RUPTURED TEST SPECIMENS 

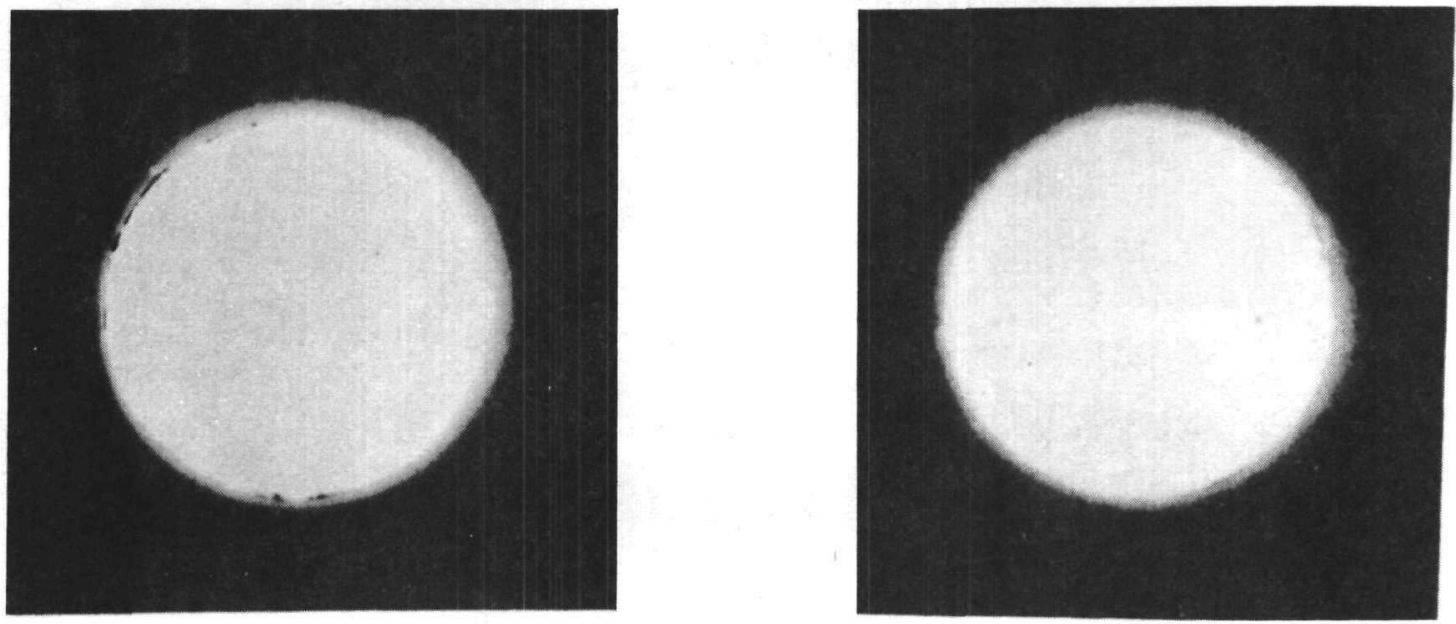

SPECIMEN T-28

SPECIMEN T -29

FIGURE 8-9

PRINTS FROM X-RAY FILM OF WELD SECTION

SPECIMENS T-28 AND T-29

No defects appear in either specimen. 

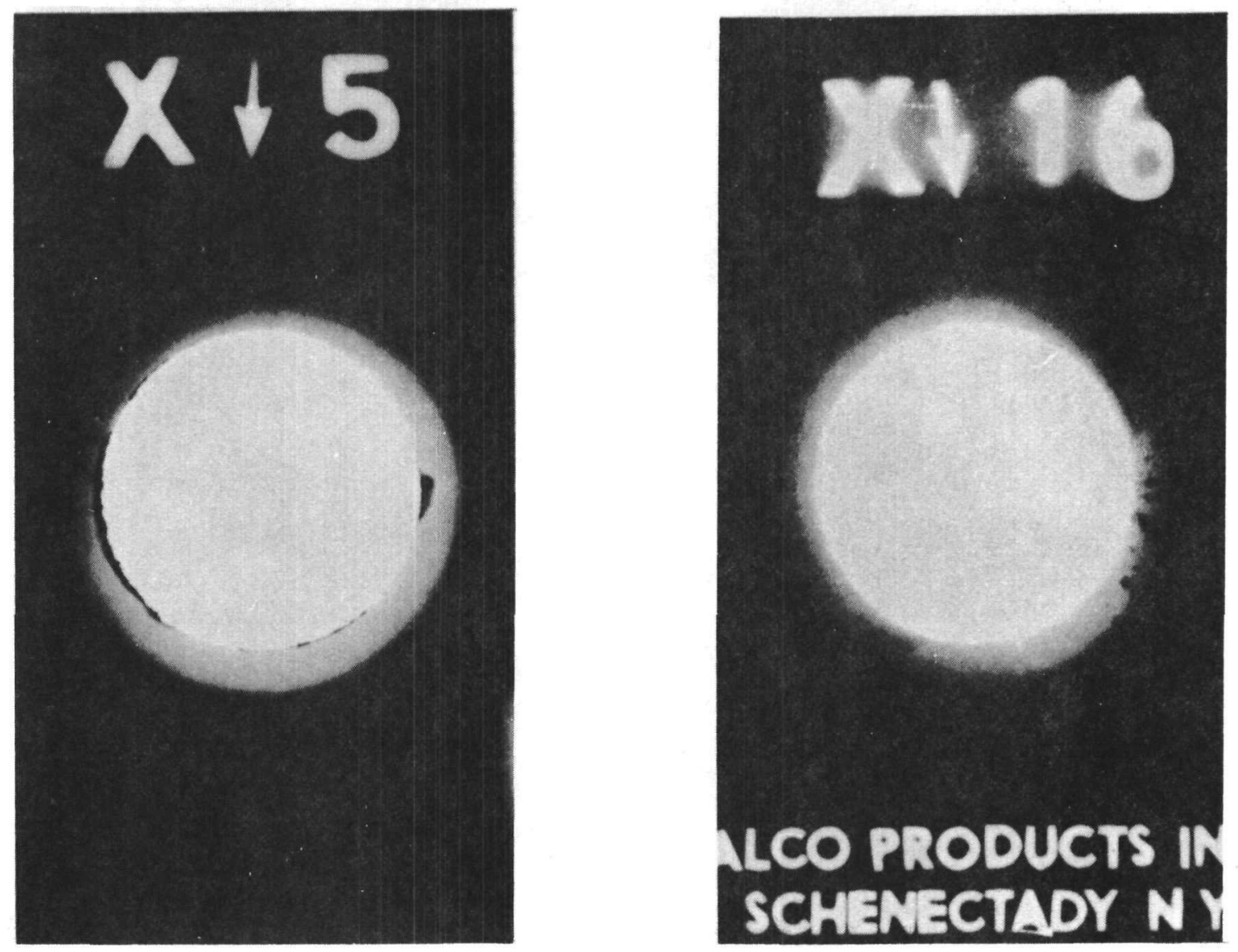

SPECIMEN X-5

Note Concavities at weld root.

SPECIMEN X-16

Note heavy porosity.

FIGURE 8-10

PRINTS FROM X-RAY FILM OF WELD SECTION

SPECIMENS X-5 AND X-16 

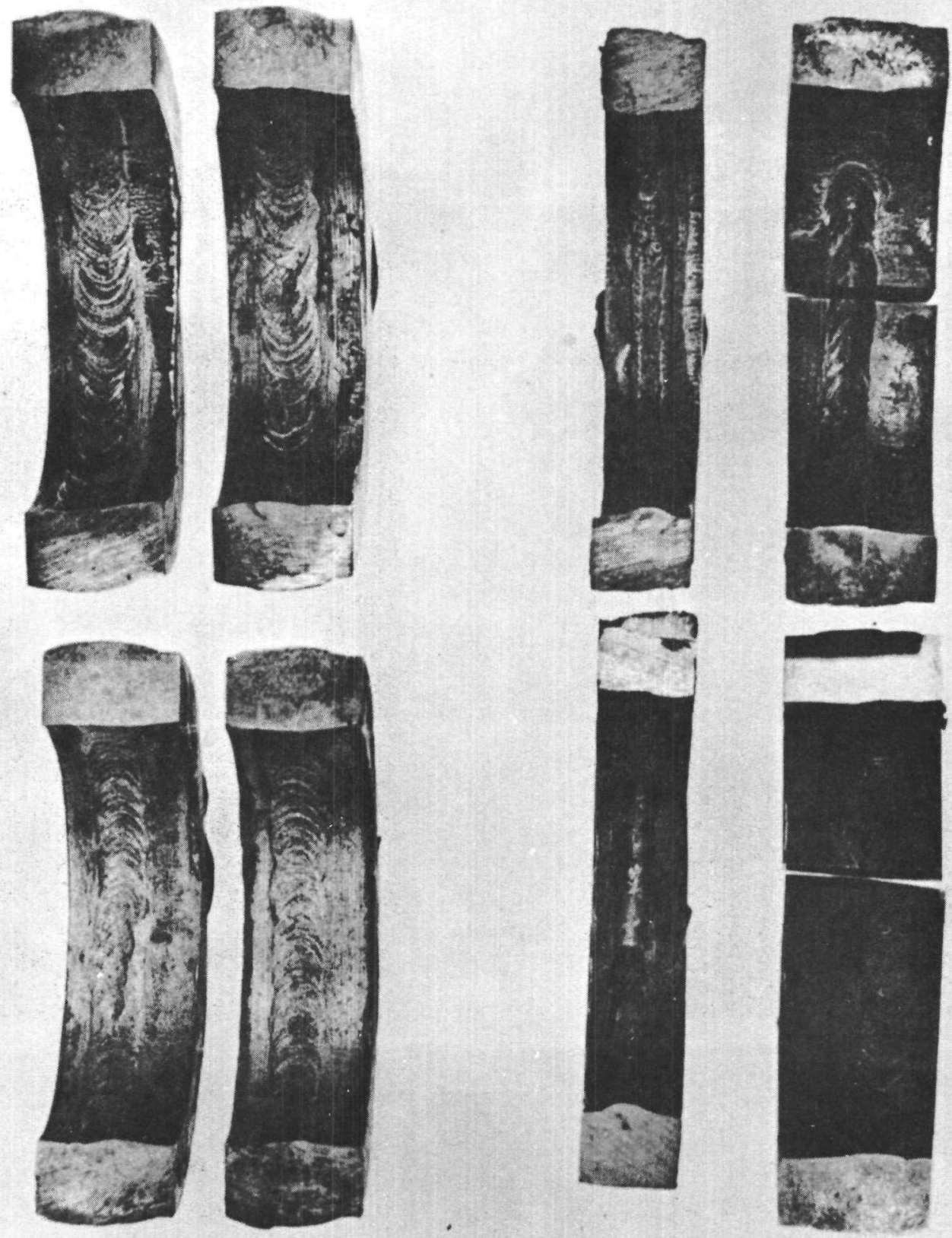

T-28

$\mathrm{T}-29$

$\mathrm{X}-16$

$\mathrm{X}-5$

FIGURE 8-11

INTERNAL SURFACE OF WELDS FROM ALL SPECIMENS 


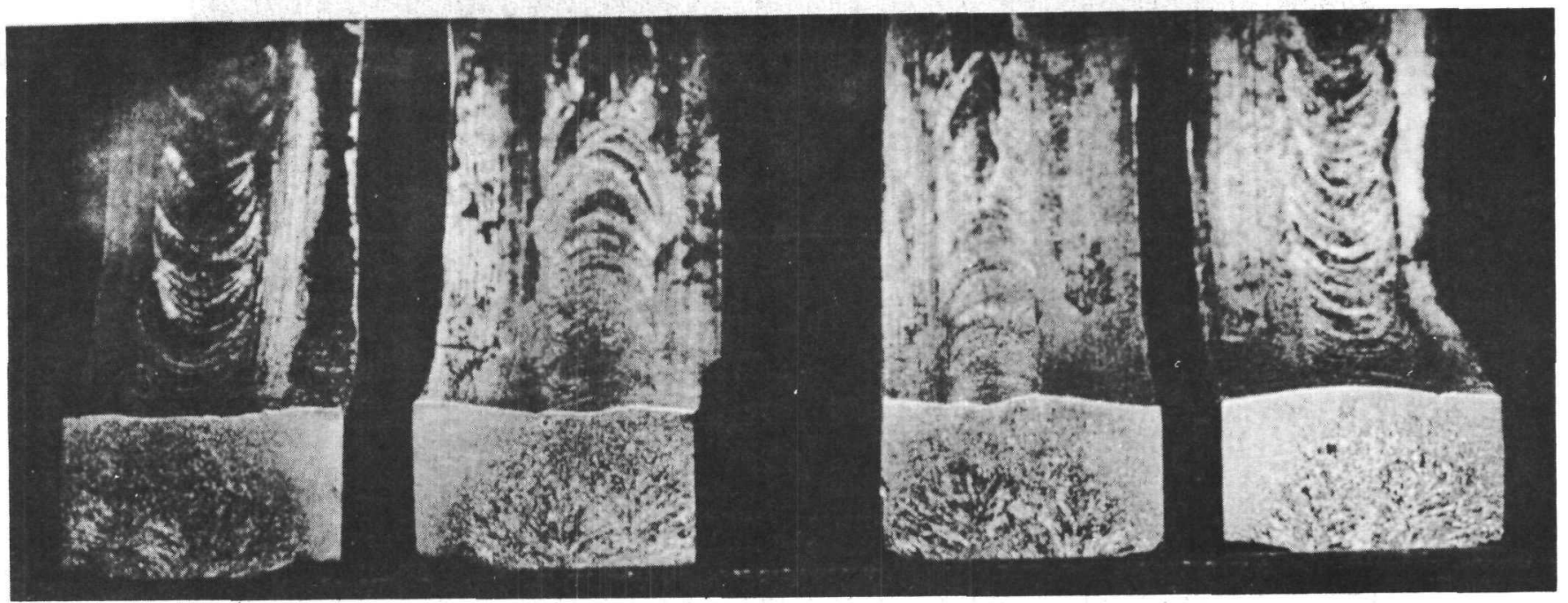

SPECIMEN T-28

SPECIMEN T-29

FIGURE 8-12

WELD CROSS SECTIONS OF SPECIMENS T-28 AND T-29 


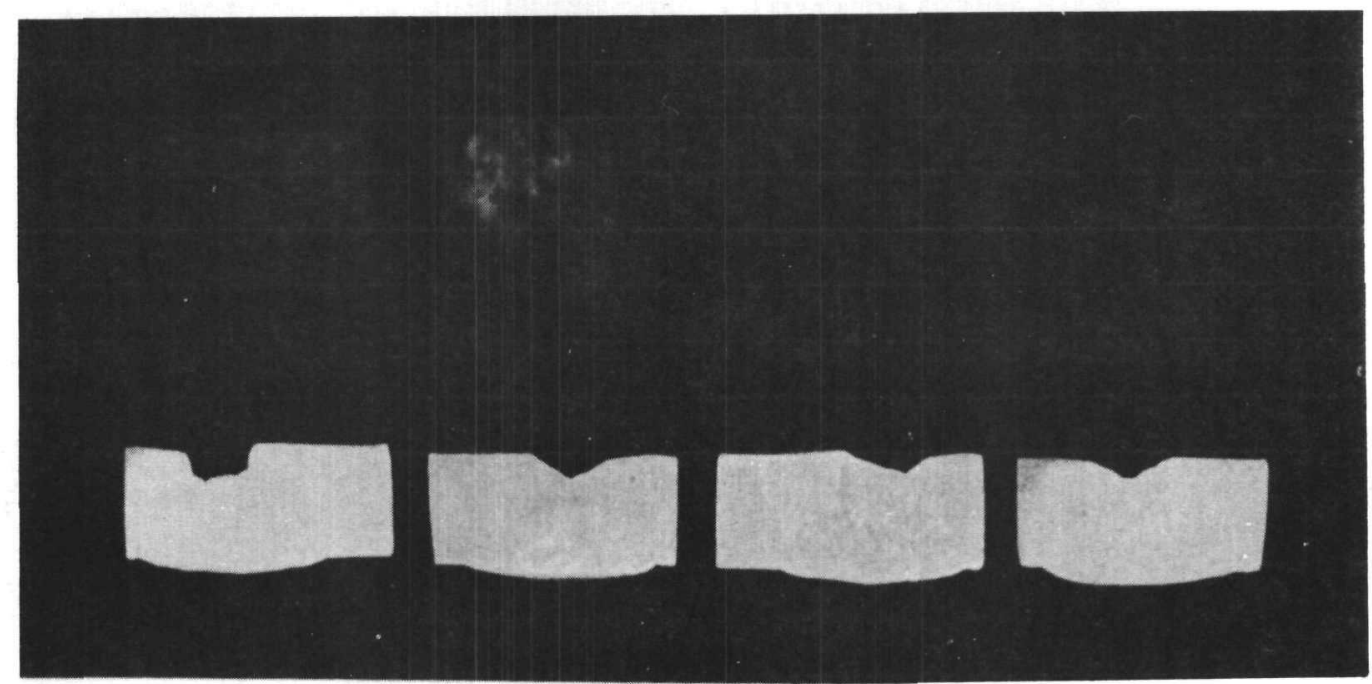

SP ECIMEN X-5

MAGNIFICATION - 2X

Note concavities at root of weld.

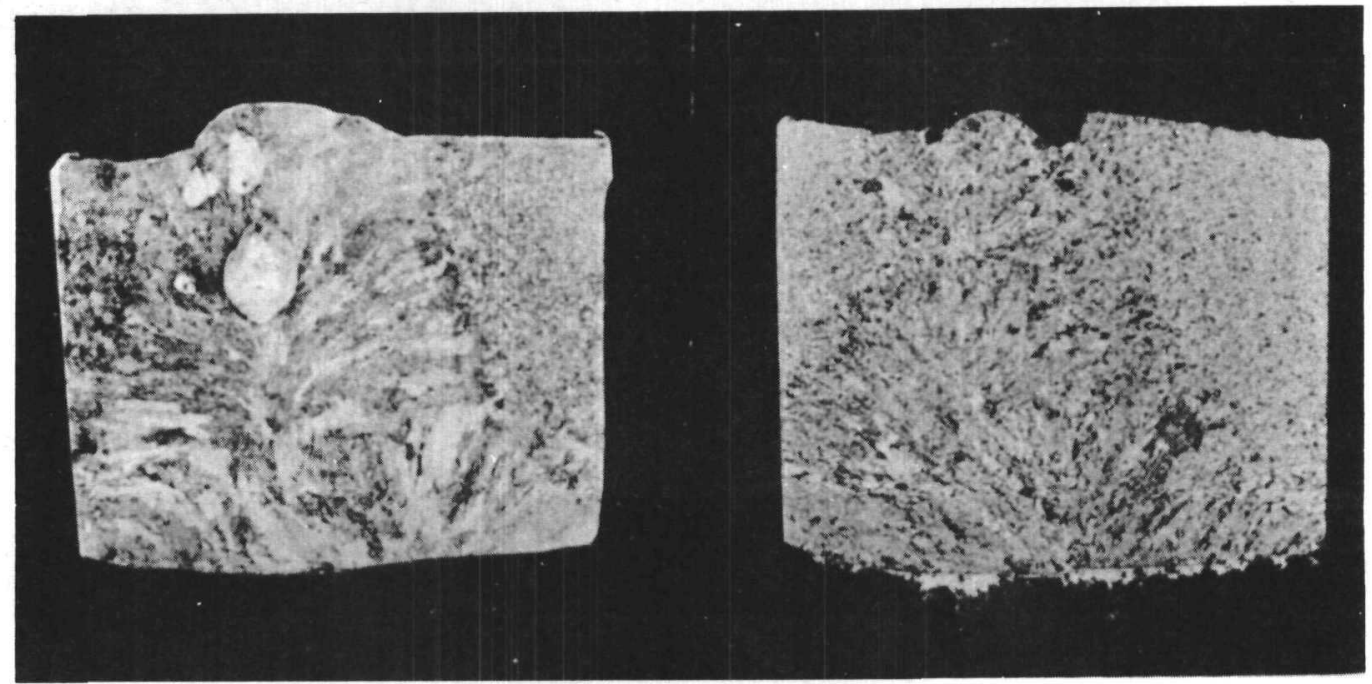

SPECIMEN X-16

MAGNIFICATION - $4 \mathrm{X}$

Note porosity in weld, specially in photograph at left.

FIGURE 8-13

WELD CROSSECTIONS OF SPECIMENS X-5 AND X-16. 


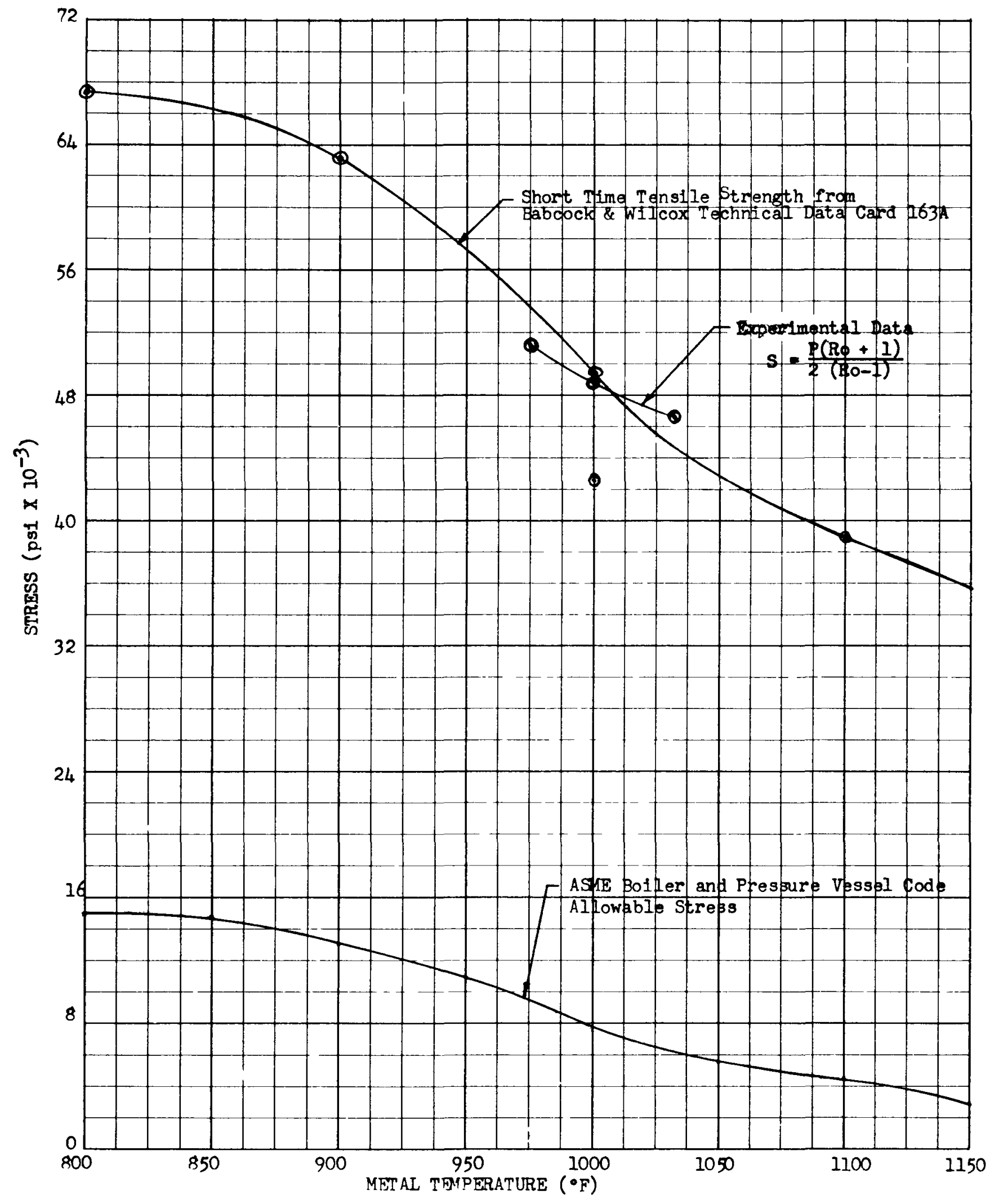

FIGURE 8-14 SHORT TIME TENSILE STRENGTH VERSUS TEMPERATURE FOR $2-1 / 4 \% \mathrm{Cr}-1 \%$ MO TUBING MATERIAL 


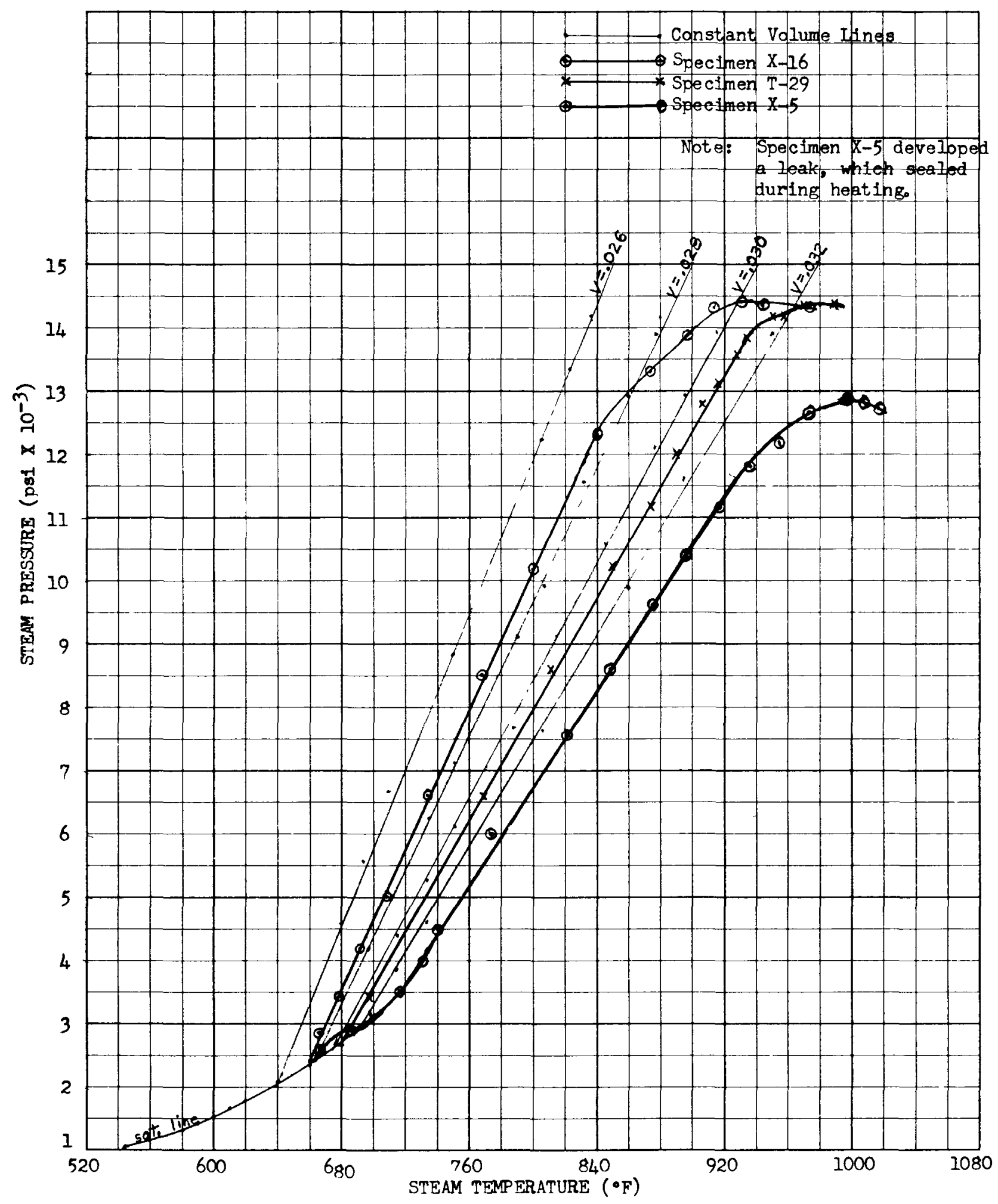

FIGURE 8-15 STEAM TEMPERATURE VERSUS RRESSURE HEATING CURVES FOR TEST SPECIMENS 